Florida International University FIU Digital Commons

\title{
The Opposition to Latin American Liberation Theology and the Transformation of Christianity, 1960-1990
}

Sonia M. Scheuren Acevedo

FIU, ssche037@fiu.edu

DOI: $10.25148 /$ etd.FIDC000270

Follow this and additional works at: https://digitalcommons.fiu.edu/etd

Part of the Catholic Studies Commons, Christian Denominations and Sects Commons, Christianity Commons, and the Religious Thought, Theology and Philosophy of Religion Commons

\section{Recommended Citation}

Scheuren Acevedo, Sonia M., "The Opposition to Latin American Liberation Theology and the Transformation of Christianity, 1960-1990" (2016). FIU Electronic Theses and Dissertations. 2454.

https://digitalcommons.fiu.edu/etd/2454 


\title{
FLORIDA INTERNATIONAL UNIVERSITY
}

Miami, Florida

\section{THE OPPOSITION TO LATIN AMERICAN LIBERATION THEOLOGY AND THE TRANSFORMATION OF CHRISTIANITY, 1960 - 1990.}

\author{
A thesis submitted in partial fulfillment of \\ the requirements for the degree of \\ MASTER OF ARTS \\ in \\ RELIGIOUS STUDIES \\ by
}

Sonia M. Scheuren Acevedo 
To: Dean John Stack

Green School of International and Public Affairs

This thesis, written by Sonia M. Scheuren Acevedo, and entitled The Opposition to Latin American Liberation Theology and the Transformation of Christianity, $1960-1990$ having been approved in respect to style and intellectual content, is referred to you for judgment.

We have read this thesis and recommend that it be approved.

Christine Gudorf

Oren B. Stier

Ana María Bidegain, Major Professor

Date of Defense: March 30, 2016

The thesis of Sonia M. Scheuren Acevedo is approved.

Dean John Stack

Green School of International and Public Affairs

Andrés G. Gil

Vice President for Research and Economic Development and Dean of the University Graduate School

Florida International University, 2016 


\section{DEDICATION}

To the three amazing people that have supported me with their trust, love and wisdom: Eduardo, Ariana and Ana María, my husband, my daughter and my professor.

To my parents, Luz Estela and Felix, two stars on my life, two life heroes. 


\section{ACKNOWLEDGMENTS}

My first acknowledgment must go to Dr. Ana María Bidegain, my major professor, who not only gave me the academic orientation to develop this research, but also her great humanity, kindness and willingness. This research has her spirit and my endless gratitude for her guidance.

Special thanks to Dr. Christine Gudorf, member of my Graduation Committee, for her wise comments, corrections and suggestions on this work.

I wish to specially thank Eduardo, my husband, for his unconditional support and love during the research and writing of this thesis, not to mention his incredible collaboration with the National Archives trips and research. In the same manner, I wish to thank my friend Bibiana Ortega for her help doing research in the National Archives. I am also grateful to Dr. Joseph Holbrook and Miguel Asencio for giving me the opportunity to work with the Carlos Uran \& Ana María Bidegain's Collection at the Green Library at Florida International University. Thanks to Carlos, Shelly and Jeanette at the FIU Writing Center for their valuable support. Equally, I want to express my gratitude to Dr. Oren Stier, Graduate Program Director and member of my Committee, the Religious Studies Department wonderful staff, Yusimi and Luz, Professors, and my dear fellow colleagues Komal, Raymond, Yehonatan, Anthony, Meisam, Yoletta, David, Patrick, John and Rania for providing me with an academic, cordial and supporting environment.

Finally, I am very grateful and blessed to have the immense affection and support of Ariana, my daughter, my parents, and my siblings Susa and Ivan. 


\section{ABSTRACT OF THE THESIS}

THE OPPOSITION TO LATIN AMERICAN LIBERATION THEOLOGY AND THE

TRANSFORMATION OF CHRISTIANITY, 1960 - 1990.

by

Sonia M. Scheuren Acevedo

Florida International University, 2016

Miami, Florida

Professor Ana María Bidegain, Major Professor

This thesis aims to explore the political, social and religious opposition to Liberation Theology in Latin America during the 1960 s to 1990s, and the transformation of Christianity. During this period, most Latin American countries underwent social struggles and political repression in which opposition and persecution arose from dictatorial and military governments who labeled those committed to the poor as communists. Liberation Theology emerged as an ecclesial and theological trend committed to the poor, in the late 1960's and early 1970's in Latin America. This thesis traces the origins, development, expansion and repression of Liberation Theology. This work maintains that under the Cold War context and the National Security Doctrine, Liberation Theology became a target of political repression because its commitment with the poor placed it as subversive and communist. This research reveals how it was repressed with violence and the promotion of counteracting religious groups, leading to changes in Christianity. 


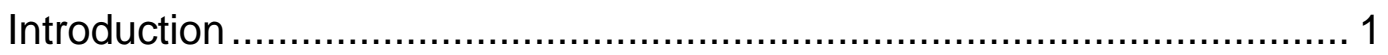

Contextual and Conceptual Framework.............................................. 1

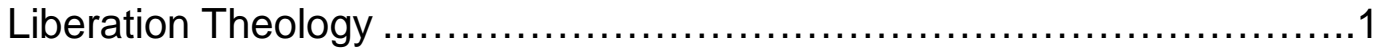

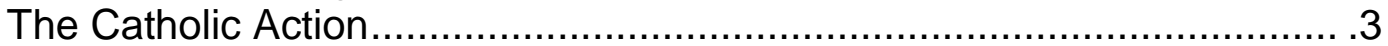

Base Ecclesial Communities (BECs or CEBs) ..................................... 4

Second Vatican Council (1962-1965) …........................................... 7

CELAM-Latin American Episcopal Conference ..................................... 8

Second Latin American Episcopal Conference, Medellin (1968) ............. 10

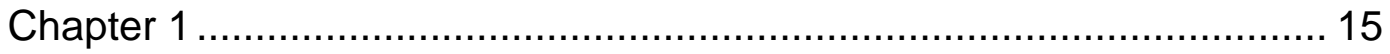

The Central Intelligence Agency (CIA) and The National Security

Doctrine in Latin America............................................................. 15

U.S. National Security Perspectives on Liberation Theology ................... 15

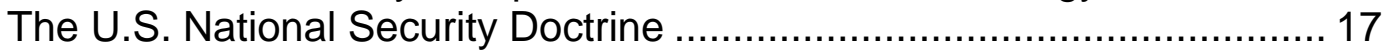

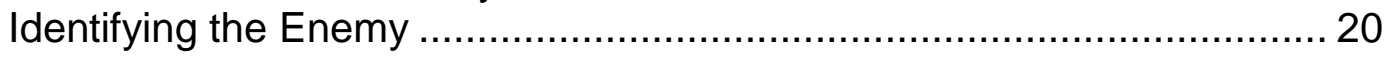

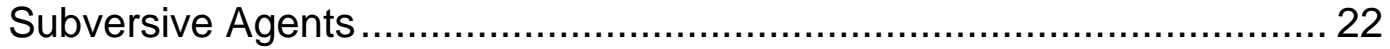

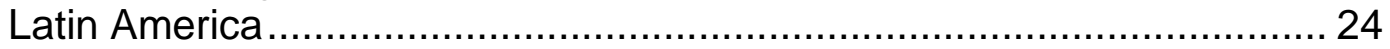

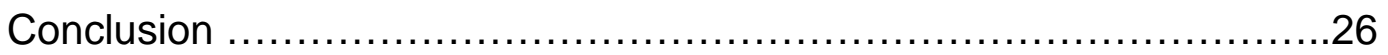

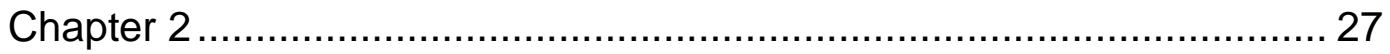

Political Opposition to Liberation Theology ........................................... 27

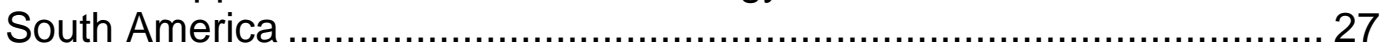

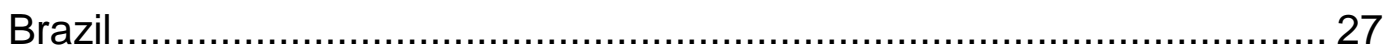

Transnational Organized Repression ………..................................... 39

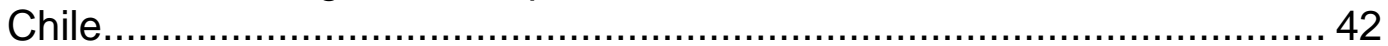

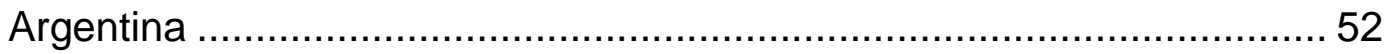

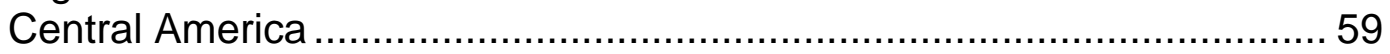

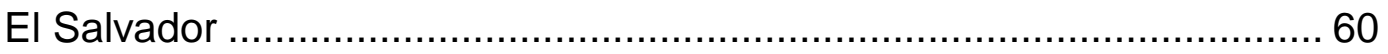

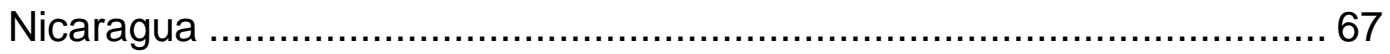

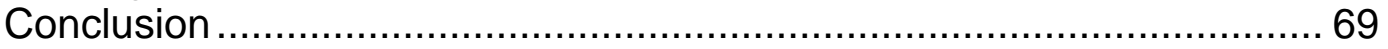

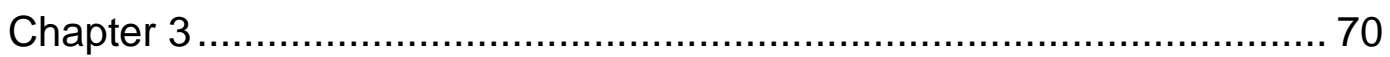

Religious and Social Opposition to Liberation Theology ......................... 70

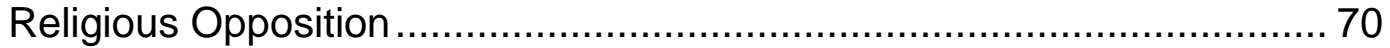

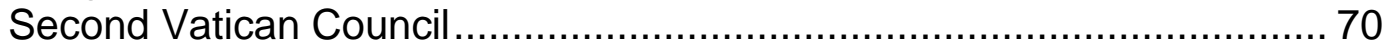

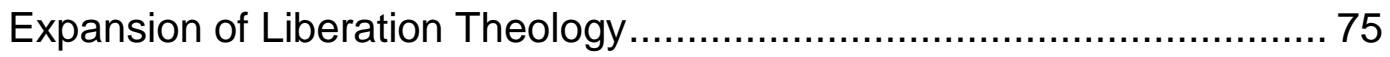

Opposition to Liberation Theology and Church Divisions ......................... 76

Religious Repression Supported by External Funds.............................. 91

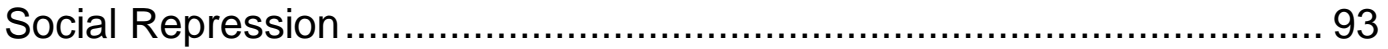




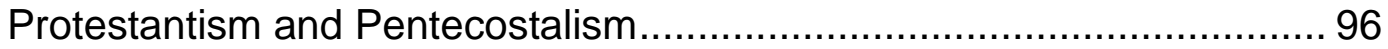

Conclusion ...........................................................

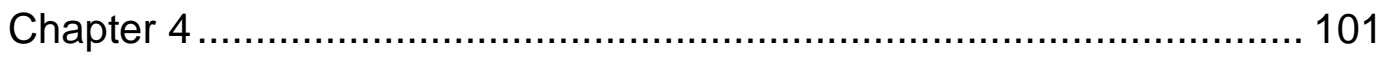

Opposition to Liberation Theology and Religious Transformation.......... 101

Changes in the Latin American Catholic Church Following the

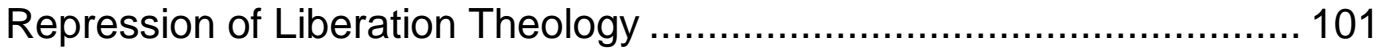

The Church as a Refuge .............................................................. 103

Religious Transformation within the Catholic Church.......................... 106

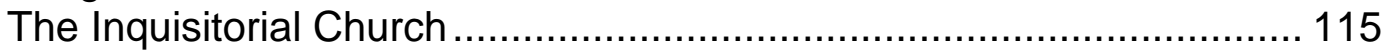

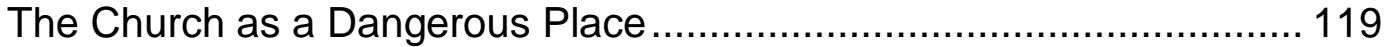

Military Repression to Radicalize the Popular Church ......................... 120

Prison-Repression to Strengthen Christianity .................................... 121

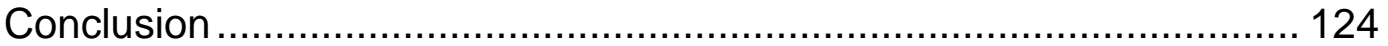

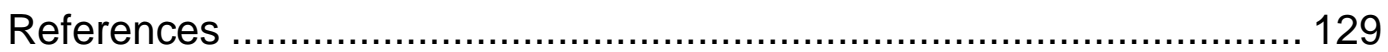




\title{
ABBREVIATIONS AND ACRONYMS
}

\begin{abstract}
AAA Argentinian Anticommunist Alliance
BEC Base Ecclesial Communities (BECs)

Card. Cardinal

CEB Comunidades Eclesiales de Base (PI. CEBs)

CEDIAL Center for the Study of Development and Integration in Latin America

CELAM Latin American Episcopal Conference (Consejo Episcopal Latinoamericano)

CLAR Latin American Confederation of Religious (Confederación Latinoamericana y Caribeña de Religiosos y Religiosas.
\end{abstract}

FGBMFI Full Gospel Business Men's Fellowship International

FMLN Farabumdo Marti National Liberation Front (Farabundo Martí para la Liberación Nacional)

FSLN Sandinista National Liberation Front (Frente Sandinista de Liberación Nacional)

ILADES Latin American Institute of Doctrine and Social Studies (Instituto Latinoamericano de Doctrina y Estudios Sociales)

IPLA Pastoral Institute of Latin America (Instituto Pastoral Latinoamericano)

Mons. Monsignor

MSTM Movement of Priests for the Third World

ONIS National Organization for Social Integration -Peru

S.J. $\quad$ Society of Jesus - Jesuits

TFP Tradition Family and Property 


\section{Introduction}

This research aims to explore from a historical perspective how political, social and religious opposition against Liberation Theology in Latin America encouraged the transformation of Christianity through the promotion of opposing religious groups between the 60's and 90's.

\section{Contextual and Conceptual Framework}

\section{Liberation Theology}

Liberation Theology arose in the late 1960s and early 1970s crystallizing the Church that was born out of Catholic Action, the grassroots and the Base Ecclesial Communities (BECs). ${ }^{1}$ Defined by theologian Gustavo Gutierrez as "a critical reflection on Christian praxis in light of the word of God," ${ }^{2}$ Liberation Theology represents a path to follow through pastoral work to reach liberation from unjust socioeconomic structures and marginalization. To clarify, theology means "the study of religious doctrines and matters of divinity . . . the study of God and the relations between God, mankind and the universe." 3 So, since its origins, Liberation Theology focused its analysis in the relationship between the Bible, as the message of God, the poor, and their oppressive reality. It entails not only a reflection, but also a praxis which is reflected upon. Thereby, Liberation

\footnotetext{
${ }^{1}$ Leonardo Boff, Church: Charism and Power, trans. John W. Diercksmeier (Eugene,OR: Wipf and Stock Publishers, 1985), 1.

2 Gustavo Gutierrez, A Theology of Liberation, History, Politics, and Salvation (Markynoll, NY: Orbis Books, 1988), xxix.

${ }^{3}$ David B. Guralnik and Victoria Neufeldt, eds., Webster's New World Dictionary of American English, Third College Edition (Cleveland, New York: Simon \&Schuster, Inc, 1988), 1387.
} 
Theology had as its core the preferential option of the poor, ${ }^{4}$ and its methodology materialized the See, Judge and Act system, which was the Catholic Action's method, later used by BECs. Historically, according to Gustavo Gutierrez in the introduction of his book, the first Liberation Theology was the systematization done by the Catholic Action students and workers, male and female.

Almost all Latin American nations underwent historically parallel social struggles and political repression within the Cold War context, ${ }^{5}$ in which opposition to and persecution of grassroots movements arose from dictatorial and military governments who labeled those committed to the poor as communists. In this vein, since Liberation Theology was engaged with the poor, it was stigmatized as communist, and therefore, repressed. For this reason, it is important to distinguish that there were two different projects. One was the political and military project that established an anti-communist crusade in the region. And the other was the religious project for social justice and human dignity focused on the preferential option of the poor.

Returning to the origins of Liberation Theology and before I define the Catholic Action and the Base Ecclesial Communities, it is important to understand modern changes within the Church, and how it got involved in the social question. It is important to remember that since the end of the XIX century, the Church embarked upon an era of social Catholicism that later welcomed the

\footnotetext{
4 Victorio Guillén Araya, "Preferential Option for the Poor," in Daniel Patte, ed., The Cambridge Dictionary of Christianity (Cambridge, New York: Cambridge University Press, 2010), 1005.

${ }^{5}$ Ana María Bidegain, "From Catholic Action to Liberation Theology: The historical process of the laity in Latin America in the twentieth century "(Working Paper, Univ. of Notre Dame, Kellogg Institute, 1985), 21.
} 
new century by promoting the participation of laymen and laywomen in Catholic Action. In 1891, Leo XIII's encyclical Rerum Novarum (Rights and Duties of Capital and Labor) set down the Church's concerns about the working class, the poverty of the masses and the consequences of industrialization. ${ }^{6} \mathrm{By}$ that time, almost half a century had elapsed since the Communist Manifesto (1848) and the Church was disadvantaged in terms of the allegiance of the working class. Its blindness kept it from recognizing the urgent need for structural reform, and the Catholic's pastoral had not provided believers with answers for coping with the social and political problems of the post-Industrial Revolution. Besides, the Church had lost political power due to the spread of democracy, and society started to be influenced by new ideas. ${ }^{7}$ Thus, due to both the shortage of priests and the necessity of bringing back followers led the Church to establish a new strategy to re-Catholize society, which was the Catholic Action.

\section{The Catholic Action}

Catholic Action was the Vatican's strategy to:

organize the laity for the defense of the Roman Catholic Church (early $20^{\text {th }} \mathrm{c}$.), which developed into a movement with a strong influence in society and political life (later in the $20^{\text {th }}$ c.). Popes called on Catholics, both men and women, of all social classes and age groups to participate in the apostolic task. For the first time, women were incorporated into the apostolic mission of the Church. Members received a mandate from the bishops and were organized at the

\footnotetext{
${ }^{6}$ Leo XIII, "Rerum Novarum", The Vatican, May 15, 1891, accessed January 31, 2016, http://w2.vatican.va/content/leo-xiii/en/encyclicals/documents/hf I-xiii enc 15051891 rerumnovarum.html

${ }^{7}$ Bidegain. "From Catholic Action to Liberation Theology, 1.
} 
parochial, diocese, national, continental, and international levels with strong ties with Rome. ${ }^{8}$

It was Pope Pius XI who formally declared Catholic Action, and the participation of laymen and laywomen in pastoral work as a mandate, in his encyclical Ubi Arcano Dei, On the Peace of Christ in the Kingdom of Christ (1922). ${ }^{9}$ Through this document, Bishops recognized the laity in their new role sharing leadership in the mission of the Church, which was the main distinction between Catholic Action and other lay organizations. Thereupon, the laity was not seen as merely an auxiliary of the clerics on the contrary, after World War I people started progressively to realize that the laity had the capability to develop their own pastoral work. Indeed, the lay task was not confined just to small groups, but rather, was a "universal mission devolving on all the baptized [sic], no longer as a privilege but as a duty."10

There were two models of Catholic Action: the General Catholic Action, and the Specialized Catholic Action. The General Catholic Action, which spread in 1930s and 1940s, was an Italian model divided in four groups, having men, women, youth and ladies. Each group assisted a particular sector of the Social Action. In this regard, adult and young men were in charged of building churches maintenance of seminaries, Catholic journalism and politics. Adult women and young ladies worked with catechism and orphanages, among activities with

\footnotetext{
${ }^{8}$ Ana María Bidegain, "Catholic Action," in Patte, ed., The Cambridge Dictionary of Christianity, 176-177.

9 Bidegain. "From Catholic Action to Liberation Theology, 4.

10 Ibid., 14.
} 
groups of single mothers and prostitution of girls. Catholic Action method of work was based on periodical parochial or diocesan meetings, and annual national or international conferences to analyze social and political problems. ${ }^{11}$

Subsequently, the Specialized Catholic Action was formed from men and women, particularly young of all social classes, grouping special sector of society such as students, workers, peasants, independent professionals and employees to engage the Church in modern times. These groups developed a strong spiritual and theological reflection that engaged them with the challenging social and political reality. They began to demand the Catholic hierarchy to be faithful to the poor as the Gospel says, and leave the alliance with the elites. This version of Catholic Action had its origins in Belgium and France, and spread in Latin America after World War II by Canadian and American priests members of the Holy Cross. ${ }^{12}$

The pastoral of the Specialized Catholic Action included the revision of life methodology, which implied three basic steps: see, judge and act. It means that first, Christians have to see, to identify their problems, specifically those related unjust and oppressive circumstances in their daily lives that have been affecting them and their neighbors. Then, they have to judge the situations identified and look for the real causes of them. For instance, if children of the community are dying because of unsanitary conditions, they must find out why the community has this critical condition, what local policies have or have not done, and how

\footnotetext{
${ }^{11}$ Ana María Bidegaín, Participación y Protagonismo de las Mujeres en la Historia del Catolicismo Latinoamericano (Buenos Aires: San Benito, 2009), 41-57.

12 Bidegain, "From Catholic Action to Liberation Theology," 11-13.
} 
these conditions could be changed. Finally, to act implies that Christians must do all they can in order to relieve the situation they are experiencing..$^{13}$ This pastoral methodology conflicted that of the pre-Conciliar church that had "stressed religious authority, personal charity and elite political action," ${ }^{14}$ while the "liberationist church came to espouse decentralized authority, social justice, and the poor as political actors. ${ }^{15}$ By the 1960's this methodology was practiced in small Christian communities that later will be called Base Ecclesial Communities (BECs) or in Spanish, Comunidades Eclesiales de Base (CEBs). In this study, I will use both acronyms interchangeably.

\section{Base Ecclesial Communities (BECs or CEBs)}

Base Ecclesial Communities represented small communities of "lower class, grassroots people, the base of society, as opposed to the pinnacle of power in the social pyramid." 16 These small groups of neighbors usually belonged to the same shantytown, village or rural zone. They gathered in their specific social locations to pray, sing, read the Bible, ${ }^{17}$ and revise their daily life, using the see, act and judge methodology originated in the Catholic Action as

\footnotetext{
${ }^{13}$ Marcelo de C. Azevedo, S.J., Basic Ecclesial Communities in Brazil: The Challenge of a New Way of Being Church (Washington D.C: Georgetown University Press, 1987),63.

${ }^{14}$ Carol Ann Drogus, Women, Religion and Social Change in Brazil's Popular Church (Notre Dame, IN:University of Notre Dame Press, 1997),29.

15 Ibid., 29.

${ }^{16}$ Leonardo Boff, Church: Charism and Power: Liberation Theology and the Institutional Church (Eugene, OR: Wipf \& Stock, 1985), 125.

${ }^{17}$ Michael Löwy, The War of Gods: Religion and Politics in Latin America (London, New York: Verso, 1996), 48.
} 
mentioned above. The Second Latin American Conference of Bishops held in Medellin, Colombia in 1968, officially supported and named the small Christian communities as Base Ecclesial Communities. ${ }^{18}$ The BECs became "the prime organizational channel for popular participation in the liberation theology movement." 19

In light of this research, it is noteworthy to explain the Second Vatican Council, the Latin American Episcopal Conference (CELAM) and its second meeting held in Medellin, Colombia, since they served as the fostering environment for the ideas of Liberation Theology. It is said, that the teachings of II Vatican Council, a meeting of all the bishops of the Church at the Vatican 1962-1965, consolidated the Church's commitment to social concerns, specifically with the poor. Then, CELAM's Medellin meeting in 1968, following Vatican instructions, formally engaged the Latin American Catholic Church in the preferential option of the poor, emphasizing the urgency for social justice and human dignity in the region. This Church commitment to social change prepared the soil to concretize the quest for social justice, and liberation from the oppressive conditions of poverty, which was the core of Liberation Theology.

\section{Second Vatican Council (1962-1965)}

In the Catholic Church a church council is:

\footnotetext{
${ }^{18}$ Ana María Bidegain, “ CELAM," in Patte, ed., The Cambridge Dictionary of Christianity, 180.

${ }^{19}$ Christian Smith, The Emergence of Liberation Theology: Radical Religion and Social Movement Theory (Chicago, London: The University of Chicago Press, 1991), 19.
} 
assembly of bishops convened to regulate doctrine or discipline. "Council" (derived from Latin) and "synod" (derived from Greek) have the same meaning, but the former term is often applied to ecumenical councils and, in the West, to gathering of bishops representing the entire Roman Catholic Church (listed by their location, e.g. Vatican II. ${ }^{20}$

In this vein, Vatican Council II represented the group of assemblies held during 1962 to 1965 in the Vatican with the purpose of reviewing Church doctrines and the role of the Catholic Church facing modern times. It formally began with Pope John XXIII and ended during the papacy of Paul VI, who called the attention of the bishops gathered for the Second Vatican Council to the situation of third world people, working class and women. Likewise, the Council introduced the transformation of the traditional hierarchical model of the Catholic Church and accepted participation of the laity in the evangelization process. Through Vatican Council documents, the Church aimed to show its concern about poverty on a global scale. ${ }^{21}$ Vatican Council II was an openness to the world.

\section{CELAM - Latin American Episcopal Conference}

The Latin American Episcopal Conference, known as CELAM for its Spanish initials, was created in 1955, thanks to the visionary proposal of Brazilian Bishop Dom Helder Camara and Don Manuel Larrain, Bishop of Talca,

\footnotetext{
20 Patte, ed., The Cambridge Dictionary of Christianity, 282.

${ }^{21}$ Donald Dorr. Option for the Poor: A Hundred Years of Vatican Social Teaching. (Maryknoll,NY: Orbis Books,1992),177.
} 
Chile. ${ }^{22}$ The Vatican, during the papacy of Pius XII, approved the Bishops' initiative. CELAM is an organization of the Vatican's Congregation for Bishops, and its Pontifical Commission for Latin America, designated to provide for the region's 22 National Episcopal Conferences, pastoral support and religious development. This task is developed through training programs, reflections, and research services, according to the political and socio-economic circumstances. Besides, the organization, in its General Conferences, determines "the direction of the Catholicism in the continent." ${ }^{23}$ As shown above, CELAM is a branch of the Vatican in Latin America in charge of the coordination and supervision of the religious development and ecclesial life, according to the Roman Curia's mandate, adapting it to the region's reality. Since Pope Paul VI, the Vatican recalled the importance of the bishops' work in the development of their individual churches:

From the very first centuries of the Church bishops, as rulers of individual churches, were deeply moved by the communion of fraternal charity and zeal for the universal mission entrusted to the Apostles. And so they pooled their abilities and their wills for the common good and for the welfare of the individual churches. ${ }^{24}$

Subsequently, II Vatican Council formally supported the role of the Episcopal Conferences, when declared:

\footnotetext{
22 Bidegain, Participación y Protagonismo de las Mujeres en la Historia del Catolicismo Latinoamericano, 99.

23 Ana María Bidegain, " CELAM," in Patte, ed., The Cambridge Dictionary of Christianity, 180.

24 Pope Paul VI, "Christus Dominus", Vatican Decree, October 28, 1965, accessed December 23, 2015, http://www.vatican.va/archive/hist_councils/ii_vatican_council/documents/vatii_decree_19651028_christus-dominus_en.html. No. 36.
} 
The Second Vatican Council, in the Decree Christus Dominus, not only expressed the hope that the venerable institution of Particular Councils would be revitalized (cf. No. 36), but also dealt explicitly with Episcopal Conferences, acknowledging the fact that they had been established in many countries and laying down particular norms regarding them (cf. Nos. 37-38). Indeed, the Council recognized the usefulness and the potential of these structures, and judged that "it would be in the highest degree helpful if in all parts of the world the Bishops of each country or region would meet regularly, so that by sharing their wisdom and experience and exchanging views they may jointly formulate a programme for the common good of the Church. ${ }^{25}$

For the purpose of this study, one of the most important of CELAM's general meetings was the Second Latin American Episcopal Conference held in Medellin, Colombia in 1968; which throughout this research will be called just as "Medellin".

\section{Second Latin American Episcopal Conference, Medellin (1968)}

Following Second Vatican's teachings, Medellin signified the decisive momentum toward the option of the poor in Latin America. The meeting, entitled "'The Church in the Present-Day Transformation of Latin America in the Light of the Council", was to apply Vatican II ${ }^{26}$ to the region. The bishops emphasized the "massive structural injustice" 27 present, and introduced the concept of institutionalized violence referring to not only the widespread situation of

\footnotetext{
25 Pope John Paul II, "Apostolos Suos," Vatican, Apostolic Letter, May 21, 1998, accessed December 23, 2015, http://w2.vatican.va/content/john-paul-ii/en/motu proprio/documents/hf_ipii motu-proprio 22071998 apostolos-suos.html.

${ }^{26}$ Smith, The Emergence of Liberation Theology, 18.

${ }^{27}$ Dorr, Option for the Poor: A Hundred Years of Vatican Social Teaching ,226.
} 
injustice, but also the historical injustice embedded in the structures of the society, the laws, politics, and the economy among others. In this general assembly, "the church broke away from its historical alliances . . . . [and] the bishops made a dramatic call to create a new social order based on justice and human rights." ${ }^{28}$ The conclusions of the assembly were focused on the development of pastoral action in pursuit of human dignity and education, the commitment to the poor, raising consciousness and radical social change toward an authentic liberation from oppressive situations. In the same vein, Medellin promoted the development of Base Ecclesial Communities (BECs) to carry on these pastoral actions in order to restore social justice. ${ }^{29}$

On the other hand, from a religious-political perspective, after the Cuban revolution in 1959, many Latin American Catholics participated in discussions about Christians' duty to engage themselves in the revolutionary process. They were questioned particularly by Camilo Torres's experience, who was a priest, sociology professor, and advisor of Catholic Action students. Torres, based in the Second Vatican Council ethos, confronted the Colombian sociological reality -particularly the peasants' situation and the inequality in Colombian society -- with the Bible's advice. With other Christians and non-Christians, he decided to organize a new political party to assemble peasants, workers and students to make the revolution in Colombia. If peaceable revolution was possible, that was the goal; if peaceable revolution was not possible, they would confront the

\footnotetext{
28 Jeffrey Klaiber, S.J., The Church, Dictatorships, and Democracy in Latin America (Maryknoll, NY: Orbis Books, 1998), 5.

${ }^{29}$ Smith, The Emergence of Liberation Theology, 19.
} 
violence of the rich through a guerrilla movement. ${ }^{30}$ At the same time, Catholic youth movements began to sympathize with socialist ideas. ${ }^{31}$ Even though, as Catholics, they had been educated on the incompatibility of being Christian and Socialist according the official teaching of the Church since the XIX century, many discussions and propositions arose on how to reverse the unequal social reality.

Latin American Catholic Action laity imported European models of homologous groups. Through their religious perspective and training, they were capable to develop functions in areas such as education, economy, culture, family and politics adapted to the Latin American countries. As Catholics, they founded political parties inspired by the social teaching of the Church and counted on its support. In the early 1960s, Christian Democratic parties arose in Latin America with lay leaders. Chile was the first nation that had a Christian Democratic candidate, Eduardo Frei, elected president in 1964. These political trends brought confusions within Catholics, who were traditionally linked to the Latin American Conservative parties, so it was needed to clarify the relationship between politics and faith. As a result, Latin American theologians started to develop studies that would lead first, to discuss the relationship between religion and politics, and later to Liberation Theology's reflections. Then, as I mentioned before, II Vatican Council and Medellin provided the Church's support in the

\footnotetext{
${ }^{30}$ Edgar Camilo Rueda Navarro, "Biografía Política de Camilo Torres," El Ortiba, (n.d), accessed February 7, 2016, http://www.elortiba.org/camilo.html.

${ }^{31}$ Enrique Dussel, La Iglesia Latinoamericana de Sucre a Santo Domingo 1972-1992 (Asuncion:CEHILA-CONFEPAR,1993), 43.
} 
social question and poverty. Therefore, Liberation Theology's religious project emerged having as a core the preferential option for the poor and the quest for radical social change and human dignity.

By the mid 1970s Liberation Theology was receiving international recognition as a major theological innovation. The new Latin American theology was present in theological meetings in North America, Asia, Europe and Africa, while written works were translated into other languages. For instance, the Catholic Action students' chaplain Gustavo Gutierrez's major work A Theology of Liberation: History, Politics, Salvation (1971), was translated into English. Juan Luis Segundo S.J., was another important Latin American Liberation theologian, who was also a Catholic Action student chaplain. He became internationally renowned by his works published in French and English: Berdiaeff: Une Réflexion chrétienne sur la Personne (1963); A Theology for Artisans of a New Humanity (5 vols., 1973-74) and The Liberation of Theology (1976).In the same way, seminaries and divinity academies in North America and Europe, as well as Latin America, began incorporating Liberation Theology texts in classes and teaching classes in Liberation Theology. ${ }^{32}$

Given these previous points as a conceptual and contextual framework for this research, readers will find in Chapter 1 , an analysis of the CIA and National Security Doctrine in Latin American defining Liberation Theology movement as a subversive element. In Chapter 2, I evaluate the political repression against Liberation Theology in the region, and later examine the social and religious

${ }^{32}$ Smith, The Emergence of Liberation Theology, 23. 
opposition to the Liberation Theology movement in Chapter 3. Finally, Chapter 4 proposes religious transformation as a result of the opposition against Liberation Theology followers. For this work, I have utilized a historical perspective within the Catholic Church and the religious history area, combined with the history of political and social characteristics of Latin American countries under the Cold War context. I have applied a qualitative methodology supporting my research with primary sources from the National Archives at College Park, MD. Thus, my research is consistent and limited by findings from this specific archive's building. Likewise, I reviewed secondary sources in the Green Library, and its Carlos Uran \& Ana María Bidegain Collection, and The National Catholic Reporter newspaper. In the same way, I examined Vatican documents such as the Documents of Second Vatican Council, the Instruction of Certain Aspects of the Theology of Liberation (1984), Instruction on Christian Freedom and Liberation Libertatis Conscientia (1986), along with previous apostolic exhortations and encyclicals.

Finally, there is much research on the recent Latin American religious transformation, including the decline of Liberation Theology. However, the opposition to and repression of Liberation Theology has not been deeply analyzed from a historical and religious perspective. Therefore, I believe this work will fill an important gap in the study and growth of conflicting religious groups. 


\section{Chapter 1}

The Central Intelligence Agency $(\mathrm{CIA})$ and the National Security Doctrine in Latin America

In this chapter I will discuss first why the U.S. National Security Doctrine looked at Liberation Theology with concerns due to the challenges it represented to U.S. interests in the region. Secondly, in this section I will tackle how the CIA implemented a policy toward this theological and pastoral movement in the region. This discussion will help us to understand the CIA's stance towards the religious movement, how the institution defined it and its corresponding policies to counteract the Liberation Theology in the region, during the 1960s' and 1990's, and how these policies influenced Latin American government's attitudes and actions towards the Liberation Theology movement.

\section{U. S. National Security Perspective on Liberation Theology}

In the fall of 1985, The Directorate of Intelligence of the CIA sponsored a conference on Liberation Theology and Communism, where the goal was to examine the implications for the United States of what they called "the phenomenon of liberation theology" and the Popular Church. ${ }^{33}$ Reflections from this event were captured in a declassified document entitled Liberation Theology: Religion, Reform, and Revolution, which would denote the US government's main concerns about the movement since the 1960's. The report, including the

33 U.S. Directorate of Intelligence, "Liberation Theology: Religion, Reform, and Revolution, GI 8610028, April 1986." Accessed June 8, 2015. CIA-RDP 97R00694R000600050001-9, CIA Records Search Tool (CREST), National Archives and Records Administration, College Park, $M D$, iii. 
CIA's previously available information, suggested a "connection between Liberation Theology and the growth of instability in the Third World," ${ }^{34}$ placing particular emphasis on "the deliberate use of Liberation Theology by MarxistLeninist groups to promote revolutionary change ... and its implications for the United States." ${ }^{35}$ Likewise, the statement shows the basis of the U.S. concerns when it declares, that the Liberation Theology movement:

.... advocates a radical structuring of society on behalf of the poor and the oppressed ${ }^{36}$. . . we [the U.S.] believe the movement has been a significant force for change, largely because it promotes socioeconomic reform through grassroots political action and joins together two powerfully forces - Marxism and Christianity ..... In our view, the aspect of Liberation Theology most threatening to political stability in Third World Countries is the activist orientation of its practitioners who urge the oppressed to seek a just life now -not in the hereafter - and to use violence to accomplish this goal. ${ }^{37}$

Moreover, the CIA's document reveals that the most dangerous political aspect of Liberation Theology was not only the immediate quest for justice, through violence as they assumed, but that the religious movement "identifies the United States and capitalism as primarily responsible for the impoverishment of the Third World." ${ }^{38}$ For the U.S. government, Latin American Liberation Theology was a social and religious force threatening the region's status quo endorsed by

\footnotetext{
34 Ibid., iii.

35 Ibid., iii.

${ }^{36}$ Ibid., v.

${ }^{37}$ Ibid., v.

38 Ibid., v.
} 
the U.S. political and economic structures. These structures were distinctive for being anticommunist and capitalist. Thus, understanding these U.S. premises, where Liberation Theology is linked to Marxism and considered as a source of political instability and violence promoter, the religious movement and its followers were targets of repression within the Cold War context and the National Security Doctrine.

\section{The U. S. National Security Doctrine}

The US National Security Doctrine arose after World War II, as an anticommunism crusade. The doctrine postulated a bipolar world divided into two antagonistic and irreconcilable parties: the West and Communism. ${ }^{39}$ Thus began a period of permanent war that avoided major military confrontations, and was known as the Cold War. This permanent war took place in all social, political, economic and psychological fields. ${ }^{40}$ For this reason, founded in geopolitical and geostrategic perspectives, the National Security doctrine created a system that encompassed all human sciences to provide an integral program of action against Marxism and anti-capitalist threats. ${ }^{41}$ This system introduced a new form to perceive and value the political realm, since the war synthesized both social

\footnotetext{
39 José Comblin, Doctrina de Seguridad Nacional I (San José, Costa Rica: Editorial Nueva Década, 1988), 17.

40 Ibid., 42.

${ }^{41}$ Ana María Bidegain de Uran, Nacionalismo, Militarismo y Dominación en América Latina (Bogotá: Facultad de Filosofía y Letras, Departamento de Historia, Edición Universidad de Los Andes, 1983), 157. (own translation)
} 
and political spaces, which is defined by Dussel as "total war". ${ }^{42}$ According to Dussel, "total war" refers to the U.S. political, neo-liberal economic, psychosocial and military strategy. ${ }^{43}$ Thus economic, political, social and military disciplines aligned with the National Security Doctrine, through the cohesive development of educational programs, strategies and policies. In this doctrine, a new type of state emerges, where security institutions will nullify legislative and judicial branches. These security institutions became the only ones responsible for handling national security's menacing situations. In other words, since everything became a matter of national security, national security institutions ruled supreme, with no space for other concerns. Therefore, in the National Security Doctrine it is the survival of the government which counts rather than the welfare of the citizens or social justice. In addition, the Supreme Power now rests on the National Security Council, that will work together with Information Offices, be in charge of defining new policies and have unlimited control over other state or private entities. ${ }^{44}$ As can be seen, under the National Security Doctrine, the power was centralized in security institutions, whose main objective was to eliminate communism and subversive individuals or groups, a goal that would lead to a repressive system. This repressive system led to persecution, torture and murders, especially across the Latin American region during the 1960s to the 1990s.

\footnotetext{
42 José Comblin, Doctrina de Seguridad Nacional I, 3.

43 Ibid., 60.

${ }^{44}$ Bidegain de Uran, Nacionalismo, Militarismo y Dominación en América Latina, 157.
} 
By the late 1950's and early 1960's, the Doctrine of National Security strengthened with the Cuban Revolution, the failure of the Bay of Pigs invasion and the Cuban missile crisis, events that geographically transformed Latin America into a crucial center of operations. ${ }^{45} \mathrm{~A}$ global warfare and anticommunist battle began with a counterinsurgency campaign based on terror. The CIA was in charge of the doctrine's expansion, establishing the "total war." 46 It is said that between the 1950's and 1975, "the United States trained 71,651 Latin American military personnel, including 8 of the region's current [by 1980] dictators, and in addition supplied $\$ 2.5$ billion worth of armaments. ${ }^{47}$ Moreover, it is not coincidental that beginning with the Brazilian coup in March 31, 1964, a frenzied escalation of violence occurred, promoted by military governments, paramilitary groups and far-right political parties in the region. Following the Brazilian military coup, in August 1971 the Bolivian military gave the power to Hugo Banzer Suarez, then in June 1973, a coup d'état took place in Uruguay and the parliament was dissolved, while in September 1973, Chilean president Salvador Allende was overthrown. The rise of political turmoil continued, with a coup in Argentina in March 1976, and the dictatorships continuing elsewhere: Stroessner in Paraguay, Duvalier in Haiti, Balaguer in Santo Domingo, Somoza

\footnotetext{
45 Kenneth P. Serbin, Secret Dialogues: Church-State Relations, Torture, and Social Justice in Authoritarian Brazil (Pittsburgh,PA :University Pittsburgh Press, 2000), 29.

46 Enrique Dussel, La Iglesia Latinoamericana de Sucre a Santo Domingo 1972-1992 (Asuncion:CEHILA-CONFEPAR,1993),60.

${ }^{47}$ Penny Lernoux, Cry of the People: The Struggle for Human Rights in Latin America: The Catholic Church in Conflict with U.S. Policy (New York: Penguin Books, 1982), 56.
} 
in Nicaragua, as well as Guatemala's, Honduras's and El Salvador's authoritarian regimes. ${ }^{48}$

\section{Identifying the Enemy}

In this environment of militarization, it is important to understand that the National Security Doctrine acted under the concept/value of absolute enemy. Once the enemy is identified, he or she has no rights; therefore, he or she must be annihilated. ${ }^{49}$ The enemy, meaning communists, must be physically, psychologically, morally and culturally destroyed. The absolute enemy in Latin America was not only communists, but rural and urban guerillas. This implied that local enemies had infiltrated the masses, which would bring the terrible reality that the people became the enemy. ${ }^{50}$ Those who pursued their own interests, political programs and social changes were seen as enemies, the same as communists, with no rights. In this vein, insurgents could be students, housewives, professionals, peasants, soldiers and religious people. Because the enemy could be infiltrated anywhere, the idea arose that each individual was responsible at his or her own level, not only for the national security, but also for the western hemisphere's security. Each person had the duty to be an informant, since the absolute enemy was not easy to recognize.

\footnotetext{
48 Dussel, La Iglesia Latinoamericana de Sucre a Santo Domingo 1972-1992, 59-60.

${ }^{49}$ Comblin, Doctrina de Seguridad Nacional I, 7.

50 Ibid., 8.
} 
As a result, it was necessary to maintain military control over the population. The enemy was on the streets, and people had to be watched, restrained and demobilized to prevent their support to the enemy. All of this caused the implementation of systematic and massive repression, including the use of torture as a fundamental strategy of political power and terror. Torture was the repression tool par excellence with a concrete objective. It not only sowed terror, but also symbolized the superiority of the state over the absolute enemy. Consequently, in order to promote national defense and protection, the enemy had to be tortured in order to reveal names of persons that could be related to social, religious or political movements considered enemies or give other secret information. This security concern justified the variety of brutal methods of torture, disappearances, and torture of the parents, grandparents or children of suspects, among with other mechanisms of control. ${ }^{51}$ These repressive methods, among other military techniques, were taught in U.S. training institutions such as the School of the Americas, also known as the School of Coups, and the U.S. Army Institute for Military Assistance at Fort Bragg in North Carolina. In the School of the Americas, during 1950 to 1973, "more than 64,000 Latin-American soldiers and officers, including 170 heads of state, ministers, commanding officers, and directors of intelligence, were exposed to such methods." ${ }^{\text {22 }}$ The Fort

\footnotetext{
${ }^{51}$ Comblin, Doctrina de Seguridad Nacional I, 8.

52 Penny Lernoux, Cry of the People, 181.
} 
Bragg academy also gave instructions in psychological operations to Latin American police agents. ${ }^{53}$

\section{Subversive Agents}

Within this military training, courses included one of the basic aspects of the National Security Doctrine, which was identifying subversive agents. According to "course $\mathrm{O}-47$, on urban counterinsurgency operations, taught at the U.S. Army School of the Americas in the Panama Canal Zone", ${ }^{54}$ it is possible to detect the presence of communists in the following scenarios:

1. Disappearance of both youths and youth movements. It is mandatory to report "the reluctance of families of said missing youths to speak about them". ${ }^{55}$

2. If peasants refuse to pay taxes, rents and agricultural loans, it is suspicious.

It indicates the existence of an active insurrection that has succeeded in convincing the peasants of the injustices of the present system, and is directing or instigating them to disobey its precepts. ${ }^{56}$

At this point, it is important to note that Liberation Theology, in its commitment for the poor, worked closely with peasants in their quest for social justice, by raising consciousness. This course's instruction concerning identifying

\footnotetext{
53 Ibid., 181.

${ }^{54}$ Ibid., 180.

55 Ibid., 180.

56 Ibid., 180.
} 
subversive agents can be seen to coincide with the activities of the Liberation Theology movement.

3. Hostility of the population against the government forces, in contrast to their neutral attitude in the past. "This can indicate a change of loyalty ....inspired by fear, often manifested by children refusing to fraternize with members of the internal-security forces." 57

4. Short or unusual absences from work of some government employees.

5. Police informants do not provide the information they should, which denotes that informants could be allied with rebel movements.

These characteristics were not the only ways to identify subversive agents. The National Security Doctrine also stated that subversion was often shown in a non-violent form. In this way, strikes, demonstrations of discontent and "consciousness-raising work," 58 like that promoted by the Catholic Church and the Liberation Theology movements, was considered subversive because it sought to reach the "historical, sociological, or economic causes of poverty and injustice in Latin America." ${ }^{59}$ Those who attempted or disobeyed the established order must have been obeying foreign and communist orders. ${ }^{60} \mathrm{In}$ fact, the $\mathrm{CIA}$ thought that Liberation Theology could be a medium to spread anti-Americanism and the Cuban revolution:

\footnotetext{
57 Ibid., 180.

58 Penny Lernoux, Cry of the People, 180.

59 Ibid., 181.

60 Ibid., 181.
} 
.... we $[\mathrm{ClA}]$ believe that the anti-US orientation of the movement and the political naivete of its practitioners make liberation theology an attractive target for Soviet and Cuban manipulation. Although Moscow so far appears to have provided only propaganda support, Cuban President Castro has seized upon liberation theology as a vehicle for rallying anti-US sentiment in Latin America and for exporting the Cuban revolution. In our view, Castro's recent easing of restrictions on the Catholic Church and Cuba's bishops indicates his interest in projecting a better international image and, more important, a growing recognition of the potential influence religious groups can exert to promote and legitimize the revolutionary process in the name of liberation theology. ${ }^{61}$

\section{Latin America}

In the anti-communist crusade, using the Nixon administration terminology, the United States was needed as a regional policeman in Latin America, to "save the Western world from communism," ${ }^{22}$ and protect U.S. interests in the region. Brazil was the chosen nation for this task. It was its duty to protect not only U.S. interests in Brazil, but also in the South American region, for which transnational military training, along with defense and intelligence systems will be developed, as we will see later in this chapter.

By the 70's, Brazil represented a strategic geopolitical nation and fostered important U.S. corporations such as Humble Oil (Standard Oil after 1959), Exxon, Coca Cola and Dow Chemical, among other investments. ${ }^{63}$ Besides, the Brazilian military strongly self-identified with U.S. policies. In this regard, General

\footnotetext{
${ }^{61}$ U.S. Directorate of Intelligence, "Liberation Theology: Religion, Reform, and Revolution, 3.

62 Penny Lernoux, Cry of the People, 167.

63 Ibid., 169.
} 
Couto Da Silva expressed that "What imperils us today as yesterday, is a threat that is leveled, not really against us, but through us against the United States." ${ }^{64}$ This identification, as Belgian theologian Jose Comblin affirmed, resulted from the Brazilian's desire to be American.

Not merely do [the Latin American elites] reject the genuine origins of their nations - African, Indian, and Iberian - but they regret that they themselves are not French, English or North American: this is alienation of a kind to be found nowhere else. ${ }^{65}$

Moreover, this Brazilian military exposure to U.S. interests had paid off, when it is known that $80 \%$ of the officers involved in the coup against Brazilian President Goulart in 1964 were trained by the U.S. army schools. ${ }^{66}$

Therefore, Brazil as the U.S.'s anti-communist regional policeman, had to identify and eliminate subversive elements. As well as in the rest of Latin American countries, subversion in Brazil became a wide and diffused concept. From a military perspective, a subversive "was someone thought to be so by the regime." ${ }^{67}$ Likewise, subversion was simply "the regime's enemy, but also its justification for existence". ${ }^{68}$ Subversion covered revolutionary and political actions prohibited by the regime, as for example the formation of dissidents and armed groups, kidnapping and bank robberies. Subversion was everything that

\footnotetext{
64 Ibid., 167.

65 Ibid., 168.

66 Ibid., 169.

67 Kenneth P. Serbin, Secret Dialogues: Church-State Relations, Torture, and Social Justice in Authoritarian Brazil (Pittsburgh,PA :University Pittsburgh Press, 2000), 21.

68 Ibid., 21.
} 
could seem leftist, criticize the regime or threaten the political status quo. For instance, student movements, protest songs, and peasant and religious organizations were considered subversive. The military and security organizations used subversion to accuse, imprison, and torture their enemies as well as real subversive elements. Repression of subversion was a mechanism to control the social order. Under these premises, anything could easily be subversive, as were Liberation Theology and the progressive wing of the Catholic Church in Latin America.

\section{Conclusion}

I have explained in this chapter how Liberation Theology and the progressive sector of the Catholic Church became subversive elements under the U.S. National Security Doctrine. The preferential option of the poor and the quest for social justice represented a threat to the status quo imposed by military regimes across Latin America with the support of the CIA. The religious-social reflection and pastoral work promoted by Liberation Theology was linked to Communism, thus the anti-communist crusade led by the United States, through its CIA office, targeted the liberationist movement and repressed it throughout the region. 


\section{Chapter 2}

Political Opposition to Liberation Theology

\section{South America}

\section{Brazil}

After reviewing the CIA's conceptual framework in Chapter 1, and in order to follow a chronological line, I will begin exploring in this chapter the influence of CIA policies in Brazil as "the United States' regional policeman," ${ }^{69}$ and its "subsatellites in the hemisphere defense system". ${ }^{70}$ Therefore, this chapter will cover major countries with the presence of Liberation Theology movements.

Understanding the wide scope of the subversive concept, in Brazil the progressive Catholic Church became a subversive agent because it criticized the regime, denounced human rights violations and worked for the poor, following Liberation Theology. Its commitment to the poor, its consciousness-raising work, and liberationists' active role promoting social justice, threatened the regime's status quo. Moreover, as Archbishop of Olinda and Recife, Dom Helder Camara wisely said, authorities and elites have mistakenly grouped in one subversive block two different people. He differentiated one group of people that are committed to an extreme left ideology and have opted for violence, and there is another group, which is moved by their religious creed and

can no longer tolerate religion interpreted and lived as an opium for the masses, as an alien and alienating force, but

\footnotetext{
69 Penny Lernoux, Cry of the People, 167.

70 Ibid., 167.
} 
want to see it at the service of the human development of those who are imprisoned in a sub-human condition. ${ }^{71}$

On the contrary, the government did not identify the differences between the two different groups as Dom Helder pointed out, and lumped them in one, targeted it as communist. Equally, the CIA's report assumed that Catholic clergy and laity, as well as Liberation Theology, were leftist:

The Catholic left -composed by bishops, clergy and lay activists- grew steadily and by late 1960s had become a major opposition force. Leftist clerics and lay leaders became increasingly outspoken against the regime ... .The emergence of Liberation Theology in Brazil...reinforced the views of leftist Brazilian clerics that the church had to become politically involved to change the social system. ${ }^{72}$

In this context, where the "leftist" Church was considered subversive, early in the 1960's, Brazilian General Murcy told Dom Jose Lamartine Soares, Archbishop of Recife, one of the "communist" archdioceses, that:

I am not a bishop, and you are. But I have the impression that my Catholicism is better than yours, because I think that if the Church does not support Communism it should not be helping to install Communism. ${ }^{73}$

\footnotetext{
${ }^{71}$ Helder Camara, Spiral of Violence (London, Sydney: Sheed and Ward, 2000),31.

72 U.S. Directorate of Intelligence, "Latin America Review, ALA LAR 85-022. October 11, 1985." Accessed June 10, 2015. CIA-RDP87T00289R000200910001-7. CIA Records Search Tool (CREST), National Archives and Records Administration, College Park, MD.

${ }^{73}$ Serbin, Secret Dialogues, 59.
} 
Along the same lines, General Castello Branco told Dom Helder Camara, "the Church was abandoning its religious functions and exaggerating its involvement in the affairs of the state." ${ }^{74}$ In turn, the Church, through the Central Commission of the Conferência Nacional dos Bispos do Brasil (CNBB) had inisisted that, "'no one can ignore the outcry of the masses who, martyrized by the spectre of starvation, are reaching the point of despair in some places'". ${ }^{75}$ While the Communists were taking advantage of this critical situation, the Bishops' Commission said, the Church "'can cry out for a social order based on the principles of revealed truth and the norms of justice and equity"'. ${ }^{76}$ In this regard, it is important to recall that the Catholic Church, in its commitment to social justice, had organized a "national team" 77 of students and workers during the 1940's and 1950's, to counteract Communism and work for justice and equity. This national team, under Dom Helder Camara as a National Assistant for Catholic Action, formed the Juventude Operária Católica (JOC), Juventude Universidade Católica (JUC), Juventude Estudantil Católica (JEC) and Juventude Agrária Católica (JAC). Besides these organizations, and with the Movimento de Educação de Base (MEB), the Catholic Church developed the largest educational program that was focused not only on literacy training, but "more importantly with social mobilization or politicization through the concept of

\footnotetext{
${ }^{74}$ Ibid., 38.

75 Thomas C. Bruneau, The Political Transformation of the Brazilian Catholic Church (London, New York: Cambridge University Press, 1974), 76.

76 Ibid., 76.

77 Bidegain. "From Catholic Action to Liberation Theology,12.
} 
conscientização, ${ }^{78}$ which basically meant coming to full consciousness. Through these movements, the Church intended to counteract Communism and to work in a unified method, to improve the socio-economic conditions of the lower classes. The Church clearly delivered the message, "to establish Rural Catholic Action is to guarantee to the rural area a sufficiently strong mystique to counterbalance and supersede the Communist mystique."'79 Because the Catholic Church had constantly worked for the poor, opposing communist ideas, improving their living conditions and building consciousness against unfair social and economic structures, the religious institution and its followers represented a threat to the status quo.

For this reason, during the period of 1964-1968, repression against the Church and the Catholic movements notably increased, and the military persecuted, tortured and murdered leaders of the Catholic movements previously mentioned. Likewise, members of the Catholic Action, JOC and JUC were brutally repressed, and the MEB was disarticulated. ${ }^{80}$ Moreover, having the progressive Brazilian Church as leftist and opposed to the regime, the conflicting relationship Church-State was getting worse, while the Church kept denouncing the regime's human rights violations. Not to mention, that for the purpose of counteracting the Catholic progressive sector, some sectors of the army promoted Umbanda and Pentecostalism. The regime needed the Protestant

\footnotetext{
${ }^{78}$ Bruneau, The Political Transformation of the Brazilian Catholic Church, 79.

79 lbid., 76.

80 Dussel, La Iglesia Latinoamericana de Sucre a Santo Domingo 1972-1992, 64.
} 
support not for religious reasons at all, but for political reasons - religious legitimation of the state ${ }^{81}$ Hence, during these years, the government not only attacked the Church using repression and persecution, but also tried to discredit it, targeting one of its powerful progressive leaders, Dom Helder Camara.

Early in 1968, a campaign against progressive bishops spread in the Northeast, alleging corruption in the use of German funds. It is known, that many northeastern bishops received funds from German Catholic organizations, such as Misereor and Adveniat, to develop different projects in the zone. Some bishops invested some capital in order to increment funds, which resulted in an obvious swindle: they lost the money, and enemies of the Church used this issue to defame Dom Helder and his group, although they were not involved in the investment. Dom Helder, knowing the facts, had advised clerics against investing funds and later made a public statement where he declared:

It is nothing but a game to alienate the people from their pastors just at the time when the prelates come to demand basic reforms and to protest against those who think they are above the law. ${ }^{82}$

Facing this attack, Dom Helder's short statement clearly shows, on the one hand, the attention placed on one of the priorities avoided by the government, which was basic social and economic reforms. And, on the other hand, he denounced those who were above the law, which referred to the

\footnotetext{
${ }^{81}$ Kenneth P. Serbin, "Brazil: Religious Tolerance, Church-State Relations, and the Challenge of Pluralism" in Sigmund, ed., Religious Freedom and Evangelization in Latin America. The Challenge of Religious Pluralism (Maryknoll, New York: Orbis Books, 1999), 214.

${ }^{82}$ Bruneau, The Political Transformation of the Brazilian Catholic Church, 130.
} 
regime's abuse of power. He was not denying the clerics' fault, but rejecting the dark interests behind the retaliation, since the government was allied with some conservative religious members, who supported and spread the corruption issue. This reveals that there were tensions within the Catholic Church, internal conflicts between conservative and progressive bishops that will be reviewed in Chapter 3.

It is important to note one of the most important religious meetings in Latin America that took place in October 1968, where Brazilian bishops -- headed by Dom Helder Camara -- assumed a leadership role. This was the Second General Conference of Latin American Bishops, held in Medellin, Colombia. This meeting, convoked by Pope Paul VI, was to provide the region's most progressive Church documents. The council's main objective was to spread Vatican II's teachings, which would promote the "ecclesial liberation in Latin America." ${ }^{83}$ Latin American bishops were focused on capitalism, socioeconomic development, social justice and the region's oppressive social and political structures. These conditions brought what the bishops called "institutionalized violence". In this context, bishops declared that, "Latin American underdevelopment . . . is an unjust situation which promotes tensions that conspire against peace." ${ }^{84}$ The final meeting's document encouraged "consciousness-raising evangelization," 85 recognized the "peaceful revolutionaries" 86 and invited

\footnotetext{
${ }^{83}$ Serbin, Secret Dialogues., 115.

${ }^{84}$ Ibid., 115.

85 Ibid., 115.
} 
Christians and laity to become betrothed to the region's social transformation. This declaration became the fundamental guideline of Latin American progressive Catholicism in formalizing the preferential option of the poor and the Base Ecclesial Communities (CEBs), the foundation of Liberation Theology. ${ }^{87}$ It is relevant to mention, that Medellin, as the meeting later was known, reinforced the Church's commitment for the poor and social justice across the region, with special impact in Brazil at the beginning. By 1968, the progressive Brazilian Church had experienced four years of intense political repression due to its work towards social transformation and its denouncements of the regime's human rights violations. Besides, as I have mentioned, the Brazilian Catholic Church, by the hand of Dom Helder Camara and its collaborators, had organized a national team to implement a Christian plan promoting economic development, and reforms in social and political structures. Somehow, Medellin empowered or legitimized the role the progressive Catholic Church had been developing in Brazil, and began to serve as a model to spread in the region, since the Latin American Episcopal Conference (CELAM), and its departments became the main pastoral coordination of the Latin American Catholic hierarchy and also the most influential theological and pastoral organization within the Latin American Church and in many other Churches in the world, regarding the reception of the Second Vatican Council and the way to adapt it to a concrete regional reality. Nonetheless, Medellin also stimulated Church divisions, and conservatives

\footnotetext{
${ }^{86}$ Ibid., 115.

87 Ibid., 115.
} 
initiated a campaign against clergy active in social advocacy and Liberation Theology, ${ }^{88}$ that will be explored in Chapter 3.

In the meantime, back in Brazil in 1968, the repression and persecution, as well as protests, urban terrorism and criticism against the government continued. This environment led the government to decree Institutional Act No. 5, which gave the executive power to close Congress and other legislative assemblies, remove citizens from office and political activities, eliminate the rights of habeus corpus and in effect subvert the 1967 Constitution, which itself had been dictated by the military. ${ }^{89}$

Institutional Act No. 5 exposed the regime's illegality, and at the same time, its super-legality, to arbitrarily act and do whatever they want. This radicalization responded to a fear of subversion, which caused an upsurge of violence, or as Dom Helder Camara better presented, "there is a real threat of an escalation of violence, of seeing the world fall into a spiral of violence." ${ }^{90}$ In Brazil, the Institutional Act No. 5 did proliferate a spiral of violence in which the Catholic Church and Liberation Theology were victims of repression. The Church became virtually the most prominent institution denouncing the regime, so repression of priests intensified. In 1969, the brutal torture and assassination of Father Antonio Henrique Pereira Neto, 28 years old, JUC Assistant and close collaborator of Dom Helder Camara, made bishops strongly condemn the regime's policy of

\footnotetext{
88 Serbin, Secret Dialogues, 115-116.

${ }^{89}$ Bruneau, The Political Transformation of the Brazilian Catholic Church, 178.

${ }^{90}$ Helder Camara, Spiral of Violence, 30.
} 
torture. ${ }^{91} \mathrm{His}$ crime? To have been chaplain to the students of the University of Recife." 92 The government did avoid talking about Pereira's murder and government's investigations were unclear. However, the Department of State had some information about this case. Later in September 1972, a telegram from the US Consulate in Recife mentions Rogerio Matos do Nacimento, indicating the court judge has him as a co-author of Father Henrique's assassination..$^{93} \mathrm{~A}$ few days later, another telegram states, that the U.S. Press reported that Pernambuco State's police solved Father Henrique's murder in June 1969, and was linked to a group of drug pushers. Matos do Nacimento was convicted of crime, nonetheless "we [the U.S Embassy] have no records indicating anyone ever convicted for this murder". ${ }^{94}$ This may suggest that for some reason the U.S. government wanted to manipulate public opinion by silencing the murder, even if they did not have anyone convicted. Besides, they had their own records about Brazilian judicial issues, but it is not clear how they obtained that information. Also, they had followed Father Henrique's murder, which denotes their interest or surveillance in the Church and its actions. On the other hand, Serbin sustained

\footnotetext{
${ }^{91}$ Mainwaring, The Catholic church and Politics in Brazil, 1916-1985, 99-100.

${ }^{92}$ Camara, Spiral of Violence, 17.

${ }^{93}$ Da Silveira, Consul in Recife, to Secretary of State, Washington, Telegram, September 8, 1972. General Records 59, Subject Numeric Files 1970-73, SOC 6-2 BRAZ to SOC 14 BRAZ, Box 3054, National Archives and Records Administration, College Park, MD.

94 Department of State to ARA/BR: WDMCLAIN.JR:ME, Outgoing Telegram, September 12, 1972. General Records 59, Subject Numeric Files 1970-73, SOC 6-2 BRAZ to SOC 14 BRAZ, Box 3054, National Archives and Records Administration, College Park, MD.
} 
that Father Henrique "was murdered by a right-wing group." ${ }^{95}$ This, as well as the majority of such cases of violence against church workers, was unsolved.

The case of Father Henrique was clearly a sign of the government's repression against the progressive Church and Liberation Theology, since the young priest was working for the poor as leader of JUC. Although JUC's views differed from the Marxist-Left, the anti-capitalist movement was also focused on radical social change and working-class struggle. These characteristics shared with the Marxist-Left placed the JUC movement an enemy of the regime. ${ }^{96}$ This murder prompted that a group of U.S Catholic clerics, lay activists and militants for other peace movements to protest in front of the Brazilian consulate in Chicago. The Coordinating Committee on Latin America, an anti war and antiimperialist organization, organized the demonstration. Its leader, Sidney Lens, linked the assassination to the "US policy makers," 97 and insisted that "the incident casts a stigma on the United States, since our government supports and has given mammoth aid to military dictatorship ever since it came in April 1964. ${ }^{" 98} \mathrm{He}$ also added that the act was part of an intimidation campaign against Dom Helder Camara, "the famous Archbishop of Recife" 99 and his advocacy of non-violent change. The press did not cover this protest, and some replicas in

\footnotetext{
${ }^{95}$ Serbin, Secret Dialogues, 39.

${ }^{96}$ Mainwaring, The Catholic church and Politics in Brazil, 1916-1985, 126.

97 James N. Green, We Cannot Remain Silent. Opposition to the Brazilian Military Dictatorship in the United States (Durham, NC, London: Duke University Press, 2010),109.

98 Ibid.,109.

99 Ibid.,110.
} 
other U.S cities, but it indicates that the government's repression in Brazil was internationally known, because of Dom Helder's crusade around the world denouncing the repression in Brazil. And Washington did not want public exposure of events that could reveal its cooperation in Brazilian national security procedures.

In 1970, six Dominican friars were arrested and tortured because they were linked to Ação Libertadora Nacional (ALN), a communist guerrilla movement. One of them, Father Tito de Alancar, 27 years old, was severely tortured, and during his cavalry, he wrote a letter describing his experience, ${ }^{100} \mathrm{a}$ message that became a symbol for human rights movements. Progressive bishops in the Amazon, committed to the work for peasants and Indians, suffered threats of death and imprisonment, as did Dom Pedro. His pastoral letter "A Church in the Amazon in Conflict with the Latifundia and with Social Marginalization," ${ }^{101}$ was the cause. His message was against capitalism and foreign company's abuses against poor people.

Dom Pedro described, in Sao Felix, one large company had burned down the houses and public buildings of a village of 500 people lived. Landowners had hired two men to kill one of the region's priests, but the men denounced the company instead, then fled the region. ${ }^{102}$

In the same way, repression against priests in the Northeast of Brazil were common. The charismatic and progressive Dom Helder Camara had the

\footnotetext{
100 Lernoux, Cry of the People, 321.

101 Mainwaring, The Catholic church and Politics in Brazil, 1916-1985, 89.

102 Ibid., 88.
} 
leadership of the region, which represented a contest for the government. He, together with his northeastern progressive bishops, kept denouncing the profound injustice in the region and the military repression. In 1969, a priest of Fortaleza was imprisoned because his sermon was considered subversive, a fact that caused the Fortaleza's archbishop to close the local church as a protest, because "if the Church were to remain silent when it witnesses the violation of human rights, it would be a deplorable omission or a flagrant confession of its lack of confidence in Christ." ${ }^{103}$ Similar to this repression was the case of Father Francisco Jentel, a French missionary who worked defending the peasants from the Codeara Company's exploitation. In 1972, the company, supported by the state military police, destroyed the peasants' village of Santa Terezinha, which had about 500 inhabitants. There was an armed confrontation between the peasants and the company, where some peasants were murdered, others imprisoned and some fled. Father Jentel, even though he was not present during the conflict, was imprisoned, tried for violating the National Security Law and expelled from Brazil. The government called Father Jentel and Dom Casaldaliga, a progressive Amazon bishop, "leftists who are agitating people. They are probably agents of other countries." 104

\footnotetext{
103 Ibid., 99.

104 Ibid., 90.
} 


\section{Transnational Organized Repression}

Like Brazil, other countries of the region suffered equally extreme repression sponsored by the U.S. government through the CIA. This support took the shape a transnational secret intelligence apparatus which was clearly demonstrated with Operation Condor. Conceived as a continental security doctrine proposed by Henry Kissinger, Operation Condor was created in 1970 as a network of secret intelligence and terrorist practices in order to destroy the enemy. Following National Security Doctrine, the Condor system sought to eliminate any subversive threat. Subversives were those who had dangerous ideas that could alter the established order and pursue social justice. ${ }^{105}$ Therefore, the Catholic Church and Liberation Theology were targets of the Condor Plan. Argentinian General Jorge R. Videla was more specific about subversives, saying "a terrorist is not just someone with a gun or a bomb, but also someone who spreads ideas that are contrary to Western and Christian civilization."106

Initially, the military regimes of five nations engaged in the organization: Chile, Argentina, Uruguay, Paraguay, Bolivia and Brazil. Later Peru and Ecuador joined, and by the 80s, the organization had extended to Central America. Operation Condor became:

a well organized, sophisticated, and well-equipped network with systematized planning and training, operations and communications centers, and a chain of command in each

\footnotetext{
105 Patricia McSherry, Predatory State: Operation Condor and Covert War in Latin America (Lanham, New York: Rowman \& Littlefield Publishers INC, 2005), 1.

106 Ibid., 1.
} 
country....Chilean court referred to Condor as "an extraofficial . . . organism that unified the secret police" of member countries .... Several clandestine detention and torture centers were established in Buenos Aires explicitly for Condor's foreign prisoners. ${ }^{107}$

Similar to the Condor Plan was the Banzer Plan, which was a repressive project against Catholic progressive leaders. This plan was developed in Bolivia in 1975 during the military dictatorship of the General Hugo Banzer, and shortly adopted by other Latin American nations. In 1977, the Banzer Plan was presented in the III Congress of the Latin American Anti-Communist Confederation, celebrated in Asuncion (Paraguay), which was a branch of the World Anti-Communist League (WACL). These organizations had their origins from the Asian Peoples' Anti-Communist League and Anti-Bolshevik Bloc of Nations, alliances that in turn were inspired and supported by the U.S. Government through its CIA office. ${ }^{108}$ It is important to note, that the Banzer Plan targeted the Catholic Church and was presented in an anti-communist meeting, which denotes the conflictual mixture of the two different projects I mentioned in the Introduction. One was the anti-communist crusade, which refers to the government's military and political project. And the other, the preferential option of the poor, which refers to the Church's project to social justice and human dignity in Latin America, advocated by Liberation Theology.

\footnotetext{
107 Ibid., 6.

108 Walter Pernas, "En Dictadura y en Democracia: La Persecución a "Perico" Pérez Aguirre," Servicio Paz y Justicia Uruguay, SERPAJ, September 30, 2005, accessed January 5, 2016, http://www.serpaj.org.uy/serpajph/comunicacion/spjprensa/210_05.pdf
} 
The Banzer Plan formulated procedures for smearing progressive Catholic leaders and dividing the Church. Some of the tactics consisted in planting subversive material in Church areas, closing or banning Church publications and radio stations. ${ }^{109}$ For instance, in Uruguay, which was one of the countries that fully adopted the Banzer Plan, the regime fiercely persecuted and imprisoned progressive priests. Declassified documents from the Uruguayan intelligence and information office, DNII for its Spanish acronym, revealed a list of 180 priests considered subversive. ${ }^{110}$ The Jesuit Luis Perez Aguirre was one of the most persecuted priests by the Uruguayan dictatorship (1973-1985). Perez Aguirre was a progressive Catholic leader who worked for the poor, whom the Jesuits called those "without name," because they were ignored by the society. ${ }^{111}$ The cleric also founded the organization for families of the imprisoned and disappeared called Service, Peace and Justice, SERPAJ for its Spanish initials. His commitment to the poor and his work denouncing human rights violations marked him as a subversive element. It was said that a neighbor denounced Father Perez Aguirre, alleging that in his farm there were anti-democratic meetings. But he continued working and even after the end of the dictatorship, the Jesuit and members of SERPAJ were still persecuted. ${ }^{112}$

\footnotetext{
109 Smith, The Emergence of Liberation Theology, 195.

110 Pernas, "En Dictadura y en Democracia: La Persecución a "Perico" Pérez Aguirre."

111 lbid.

112 Ibid.
} 
The Banzer Plan also instituted a transnational intelligence office similar to that of Plan Condor, both backing up the National Security Doctrine. In this regard, it is noteworthy to mention the arrest of forty-eight bishops and priests in Riobamba (Ecuador) in 1976. According to Ecuadorian Bishop Leonidas Proaño, the clerical group's attack "was a direct outgrowth of the Banzer Plan against the Catholic Church that was drawn up in Bolivia, an economic and political satellite of Brazil." ${ }^{113}$ This statement remind us that Brazil trained in counterinsurgency methods police agents from Paraguay, Uruguay and Bolivia, playing its fundamental role as regional police, as I mentioned earlier. Others interpreted the Riobamba raid as a Condor coordination, ${ }^{114}$ which is possible since both groups pursued across borders religious elements thought to be subversive. From this perspective, the religious retreat-conference was a target, being an international encounter including priests and bishops of different Latin American nations associated with Liberation Theology. ${ }^{115}$

\section{Chile}

In Chile, by the late 1960s, a sector of the Catholic Church was particularly active in the political arena. This was a result, as Enrique Dussel explained, of the victory of the Christian Democratic party in 1964. The theologian sustained that it was not beneficial for the Church to have supported a

\footnotetext{
${ }^{113}$ Lernoux, Cry of the People, 175.

${ }^{114}$ McSherry, Predatory States, 119.

115 Ibid., 118.
} 
government that became repressive to the peasant workers, since the Church was supposed to defend them. For this reason, the Church would experience divisions in the next presidential elections. ${ }^{116}$

By 1969, the Marxist Salvador Allende was running for president, and a group of progressive Chilean lay people and priests, disappointed with President Eduardo Frei's Christian Democratic Party, began to consider supporting the Allende program. Allende won the elections on September 4, 1970. In December of the same year the International Seminar for Latin American Priests, organized by ILADES, Santiago's Jesuit research center, was held. ${ }^{117}$ In this meeting, participant Gonzalo Arroyo proposed to evaluate the meaning of Allende's triumph, after which some of the attendants decided to meet again in April 1971 to discuss Arroyo's proposition. At the 1971 meeting, 80 priests attended, hence they called themselves Los Ochenta (The Eighty). ${ }^{118}$ As a result of the meeting, The Eighty issued a statement "Christian Participation in the Construction of Socialism in Chile," ${ }^{119}$ that declared:

Chile's poverty and exploitation were the result of the capitalist system, which is produced by the domination of foreign imperialism and abetted by our own country's ruling classes .... Finding "no incongruity between Christianity and socialism," the document declared a total commitment of these priests to the realization of socialism in Chile. ${ }^{120}$

\footnotetext{
${ }^{116}$ Dussel, La Iglesia Latinoamericana de Sucre a Santo Domingo 1972-1992, 84.

117 Smith, The Emergence of Liberation Theology, 180.

118 Ibid., 181.

119 Ibid., 181.

120 Ibid., 181.
} 
This declaration brought a public response from the Chilean Catholic Church hierarchy, warning against Church participation in politics through the pastoral letter "Gospel, Politics, and Various Types of Socialism." ${ }^{121}$ Subsequently, both groups exchanged public communications and disagreements, including Uruguayan liberation theologian Juan Luis Segundo, a member of The Eighty, who critiqued the hierarchy's position, which, he said, manifested a "lack of structural analysis of capitalism, abstract language, oversimplification of Marxism, and hope for a politically neutral Church." ${ }^{122}$ Differences within the Church continued, and by the end of 1971 The Eighty founded the Christians for Socialism organization. The organization assembled not only The Eighty, but also Chilean and foreign religious members, laity and Protestant leaders. The organization compiled "much of the core leadership of the liberation theology movement,"123and counted on assistance from others Latin American radical priests' organizations, such as Peruvian ONIS (National Organization for Social Integration), Golconda from Colombia and Priests for the Third World from Argentina. ${ }^{124}$ These priests' groups, as Bidegain emphasizes, recognized popular religiosity and worked in consciousness-raising and education in order to collectively pursue the common good and social justice. But, she adds, this experience and the recognition of popular religiosity also

\footnotetext{
121 Ibid., 181.

122 Ibid.,181.

123 Ibid., 181.

124 Ibid., 181.
} 
brought up theological reflection as well as questioning issues about politics, pastoral problems in Latin America, and in the priests' own life. Priests activities were linked to the social reality and their own role in achieving better living conditions, in the light of the Christian faith. ${ }^{125}$

This activist Church sector put the U.S. Directorate of Intelligence on alert, who responded with its reactions in "Liberation Theology: Religion, Reform, and Revolution" document:

With the election of Salvador Allende in September 1970, Chile became the first major testing ground of direct collaboration between an activist church and a Marxist regime. The openness between official sectors of the Catholic Church and the Chilean Communist Party was a dramatic change from the early 1960s when the Church leadership condemned Marxism . . . . the official Church remained neutral, but continued to support social reform within a constitutional framework. Meanwhile, many priests and layworkers became open advocates of Marxism through their writings and sermons. ${ }^{126}$

After the coup that overthrew and assassinated Allende in 1973 in Chile, repression against progressive Church members arose where 165 nuns and priests were expelled from the nation, 3 were murdered and Church leaders such as Cardinal Raul Silva were victims of smear campaigns by the government. ${ }^{127}$ Equally, the Christians for Socialism organization was annihilated, and Liberation

\footnotetext{
${ }^{125}$ Bidegain. "From Catholic Action to Liberation Theology,"16.

126 U.S. Directorate of Intelligence, "Liberation Theology: Religion, Reform, and Revolution, GI 8610028, April 1986." Accessed June 8, 2015. CIA-RDP 97R00694R000600050001-9, CIA Records Search Tool (CREST), National Archives and Records Administration, College Park, MD), 15.

${ }^{127}$ Lernoux, Cry of the People, 405.
} 
theologians such as Pablo Richard, Sergio Torres, Jose Comblin (already exiled from Brazil), and Hugo Assman, among others involved in the organization, had to flee to other countries to save their lives. ${ }^{128}$ Facing the regime's violence and repression, the Catholic Church continued its efforts in following the Vatican and Medellin teachings, so it played a fundamental role organizing and leading social programs to relieve the widespread hunger, unemployment and injustice in the country. Cardinal Raul Silva Henriquez, who was a vigorous opponent of human rights violations during the Pinochet dictatorship (1973-1990), promoted pastoral renewal, agrarian reform, and founded Church committees to assist the victims of the military repression. One of these organizations was the Committee for Peace (COPACHI) established in early 1974.

COPACHI's services included a wide range of social projects such as economic self-help enterprises, farm co-ops and health clinics in poor neighborhoods. Hundreds of soup kitchens were created, providing daily lunches for more than 30,000 needy children. COPACHI's staff grew to more than 300 full-time lawyers, social workers and medical personnel. ${ }^{129}$

Soon, the organization was the subject of harassment by the military regime and by the end of 1975, 18 COPACHI's members were imprisoned and Pinochet forced Cardinal Silva to close the organization down. ${ }^{130}$ Finally, the

\footnotetext{
${ }^{128}$ Smith, The Emergence of Liberation Theology, 195.

129 David Molineaux, "Chile Honors Memory of Cardinal who Opposed Pinochet", National Catholic Reporter, April 23, 1999, accessed January 6, 2015, http://natcath.org/NCR Online/archives2/1999b/042399/042399i.htm.
}

130 Ibid. 
committee ended its functions on December 31, 1975, but the Cardinal established a new committee on January 1, 1976 called the Vicariate of Solidarity. The cleric stated,

We can close COPACHI, Mr. President, but we can never abandon our duty, Silva replied. "If you want to stop us you'll have to come looking for these people in my own house: I'll hide them under the bed if needs be." ${ }^{131}$

By 1980 , the Vicariate of Solidarity and its regional offices had assisted more than 700,000 individuals with medical, legal and social services. And even though Pinochet's security agents constantly threatened the Cardinal, the committee continued in its functions during the remainder of the dictatorship. ${ }^{132}$

It is important to mention that through the Vicariate, the Church developed a successful lunch program and 127 community industries that contributed to strengthen solidarity and cooperation among the poor. ${ }^{133}$ One member of a Christian community said,

We have gone through a difficult period, but we are learning that hunger and all the other daily problems can be solved only in solidarity. ${ }^{134}$

Participation was the key for change, as Santiago's Bishop Enrique Alvear affirmed, reflecting Liberation Theology's principles of understanding the reality through the Gospel:

\footnotetext{
131 Ibid.

132 Ibid.

133 Lernoux, Cry of the People, 402.

134 Ibid., 402.
} 
.... suffering in solidarity would purify the Church, . . . but only if the people participated in the change .... "How do we evaluate our present experiences? Are they important only because they reflect the social and political organization in Chile? Or should we discover through them a new image of the Church, more gospel-oriented, in greater solidarity with people, more independent from state and economic powers, more committed to an integral liberation for all persons, and more open to everything and everyone?"135

By 1975 , a Chilean survey showed that more that $30 \%$ of priests, nuns and laity agreed with the statement "the theology of liberation offers a valid image of the Catholic faith of the Latin American people."136

Similar to Bishop Alvear, was the experience of U.S. Father Mark Mengel, who had been working in a slum near Santiago, and was considered "an American priest who has dedicated his life to 'liberating' Latin America's poor."137 By 1979 , Father Mengel said that at least $22 \%$ of the 4 million city population were unemployed or employed by the government program gaining $\$ 30$ a month. The priest said, "'the workers are poor and the unemployed are poorer. They know that, in Chile today, the only voice to defend them is the church."'138 This affirmation supported what Medellin had said, that the Church became the voice

135 Ibid., 403.

136 Smith, The Emergence of Liberation Theology, 202.

${ }^{137}$ Charles A. Karuze, "For U.S. Priest in Chile, 'Liberation Theology' Means Bringing Dignity to Poor", The Washington Post, February 14, 1979, accessed January 7, 2016, https://www.washingtonpost.com/archive/politics/1979/02/14/for-us-priest-in-chile-liberationtheology-means-bringing-dignity-to-poor/53ed0b79-6c79-4024-a240-719f37f47009/. 138 Ibid. 
of the voiceless, or using Father Mengel's words, Liberation Theology brought dignity to the poor.

The Chilean Catholic Church was the only institution that confronted the military regime, despite a few bishops who supported it. In this regard, Luis Corvalan, the Secretary of the Chilean Communist Party exiled in Moscow, made an interesting reflected, that under these circumstances, religion cannot be considered the opium of the people; on the contrary, the way the Church committed itself to the people, it became an inspirational factor in the fight for peace, freedom and justice. ${ }^{139}$

In the same vein, the Chilean Church in its quest for justice, worked for the indigenous cause as well as for popular culture, ${ }^{140}$ and had to confront landowners and some issues. Cardinal Silva understood the importance of popular religiosity and its significance in traditional customs grounded in the Chilean indigenous groups since the sixteenth century. Silva participated and encouraged these groups to celebrate and incorporate their dances within the Catholic Mass, which represented a huge turn, since in the past these traditional dances had to be done outside the Church. An example of this was the dance festival of La Tirana, a reverence for the Virgin of Carmen. For this festivity, forty-five thousand participants practice two hours daily, five days a week during four months - all in honor of the Virgin. ${ }^{141}$ These practices and rituals constituted a great

139 Dussel, La Iglesia Latinoamericana de Sucre a Santo Domingo 1972-1992, 84. 140 Ibid., 84.

141 Penny Lernoux, Cry of the People, 404. 
stimulus for Christian communities, because they found a space to live their beliefs and express their faith and devotion. This integration can be considered as part of the evangelization success, which was possible thanks to the institutional Church commitment to the poor. ${ }^{142}$

Parallel to these changes, the repression continued, and in 1984 Andre Jarlan was murdered in an extremely poor slum. The same year, Archbishop Juan F. Fresno called upon the government to make for an urgent change in the interests of national unity. ${ }^{143}$ Regarding Archbishop Fresno, who was Cardinal Silva's successor, it is important to include, some impressions from the U.S. Directorate of Intelligence, which was monitoring the cleric's activities. Initially, the document described the influence the cleric had:

His influence has grown to the point that he may well play a vital role -perhaps second only to that President Pinochet - in determining whether the country achieves an orderly transition to civilian rule or becomes increasingly polarized over the next few years. ${ }^{144}$

This secret document, "Chile's Cardinal Fresno, A Political Primate", (November 6,1985) reveals the evolving role of the prelate, who had a reputation for prudence and moderation in contrast to "others in the church, especially Liberation Theology proponents, [who] supported political activism and outright

\footnotetext{
142 Ibid., 405.

143 Dussel, La Iglesia Latinoamericana de Sucre a Santo Domingo 1972-1992, 85.

144 U.S. Directorate of Intelligence, "Chile's Cardinal Fresno, a Political Primate, ALA-M-8510117, November 6, 1985." Accessed June 9, 2015. CIA-RDP85T01058R000100570001-3. CIA Records Search Tool (CREST), National Archives and Records Administration, College Park, $\mathrm{MD}, 1$.
} 
opposition to the regime." ${ }^{145}$ Recognizing Fresno's reputation for prudence and moderation, Pinochet surmised that future relations with the Church would no longer be conflictual, and his wife, known as his adviser, added that, "Fresno's appointment was a miracle that would 'save' the church." ${ }^{146}$ But circumstances changed. Anti-regime protests increased and Cardinal Fresno drifted apart from the regime, beginning to play intermediary between the opposition and the government. From the prelate's neutral position, he persuaded the opposition towards a national accord in order to promote dialogue in light of a transition to democracy. For this reason, the U.S. Embassy reported that Pinochet told the Papal Nuncio, "the church's oppositionist activities under Fresno had led him to consider changing his religion." ${ }^{147}$ Pinochet's response functioned as both a threat and attack, not only to Fresno, but also to the Church in general. Like other religious members who were repressed by governments after having initially supporting, "moderate" religious usually ended uniting with those fighting against human right violations.

In this vein, and similar to Fresno's case, it is important to recall the attacks on Brazilian Dom Helder Camara and Cardinal Silva we mentioned earlier, because, even if they occurred years before (1970s), they showed how repression pushed some moderate clerics back into the progressive sector:

\footnotetext{
145 lbid., 2.

146 Ibid., 2.

147 Ibid., 4.
} 
by attacking the political center of the Church, the military forced the moderates back into the ranks of the progressives

- only now there was no doubt of what was at stake. ${ }^{148}$

In like manner, another prelate member of the pro-Pinochet wing of the Church was the apostolic nuncio to Chile, Italian Cardinal Angelo Sodano. Sodano openly expressed his support for Pinochet, who awarded him the Grand Cross of the Order of Merit for his "skill and brilliance"149 in diplomatic affairs. On the other hand, the cleric was a strong opponent of Liberation Theology and Cardinal Silva, along with conservative bishops Antonio Moreno and Pablo Lizama, who together not only supported the military repression but also orchestrated religious opposition against the progressive wing of the Church, 150 as I will explain in chapter 3.

\section{Argentina}

By the same token, the progressive sector of the Catholic Church in Argentina suffered a fierce repression. Early in the 1970s, Argentina went through a period of political confrontation, where repression against popular groups increased. The Argentinian Catholic Church was divided into two stands: one allied with the elites and linked to the government, and the other committed to the popular classes. The latter had as its main exponent the Movement of

\footnotetext{
148 Lernoux, Cry of the People, 46.

149 John L. Allen Jr., "These Paths Lead to Rome: Six cardinals who got to the curia by supporting right-wing governments in Latin America, opposing liberation theology," National Catholic Reporter, June 2, 2000, accessed January 7, 2016, http://natcath.org/NCR Online/archives2/2000b/060200/060200a.htm.
}

150 Ibid. 
Priests for the Third World (MSTM for its Spanish initials), an organization that suffered a strong repression by 1973 under the Peronist right wing. ${ }^{151}$

By this time, the progressive Church had begun pastoral work in the Buenos Aires's slums called "Pastoral Action in the Emergency Villas." The pastoral team of the Emergency Villas made a statement regarding the structural problem of marginalization. They considered, contrary to anti-liberationist Roger Vekemans, that marginalization was the result of inefficient modernization plan that left aside the rural workforce. Vekemans, in turn, stated that marginalization was an excess of population unrelated to any system. ${ }^{152}$ One of the organization's founders was father Carlos Mugica, who understood the importance of the political commitment to pursue social change. For this reason, he became one of the first victims in 1974, of the security agents of Lopez Rega, who later would form the terrible triple A, or AAA, the Argentinian Anticommunist Alliance. This alliance was known as a brutal far-right death squad linked to the CIA.

Repression against the progressive Catholic Church in Argentina was reinforced by an anti-Semitic campaign widespread in the nation. The Editorial Milicia and other Nazi editorial houses launched an anticlerical campaign accusing the Church to be aligned with world Judaism and Marxism. Sharing this assumption, the military and paramilitary forces persecuted religious members working for the poor in rural areas and slums. By late 1977, "seventeen priests and nuns have been murdered, thirty were in prison, and the country's most

151 Dussel, La Iglesia Latinoamericana de Sucre a Santo Domingo 1972-1992, 68.

152 Ibid., 70 . 
outspoken bishop was dead, killed by security forces in a fake automobile accident." ${ }^{153}$

In the perspective of the security forces, Liberation Theology and the progressive Church seemed anti Argentinean and opponents to the regime's ideology. As Morello explains, repression under a state of terrorism required:

the illegal use of force by the state against opponents in order to improve a way of "being Argentinean" .... . There was an ideology that attempted to reorganize society, to transform the common order not only in political or economic terms but also in terms of morals, religion, family, and work. There were "good" and "bad" ways of being (man, woman, Christian, Argentinean, mother, student). ${ }^{154}$

Thereupon, the state established that there was only one possible way to be a good Argentinean, and any other model different from the government's one was considered evil, and carried out by perverted and sick people. ${ }^{155}$ Consequently, all those opposed to the government were evil, anti-nationalistic and must be annihilated.

That was the case of the outspoken Bishop Enrique Angelelli, who was one of the victims of this religious crusade. Angelelli constantly denounced the regime's human rights violations, and moreover, was committed to the poor. The cleric worked in the impoverished and backward zones of the Northwest of the

\footnotetext{
153 Lernoux, Cry of the People, 345.

154 Morello, SJ, The Catholic Church and Argentina's Dirty War, 59.

155 Ibid., 59.
} 
country, known as the "other Argentina," ${ }^{156}$ because of its contrast to the sophisticated city of Buenos Aires. Then, Angelelli was named Bishop of the diocese of La Rioja in 1968, a vast zone of lands, vineyards and extensive ranches. These ranches had the Indian population as the majority of peons, who were "literally treated as work animals by the white landowners." ${ }^{157}$ The bishop's teachings encouraged peasants to pursue social justice and fair wages; hence landowners soon began to call him "Satanelli." ${ }^{58} \mathrm{His}$ work continued to focus on defending workers' rights, as well as denouncing the government for the lack of minimal public services. As a result, a group of ranchers denounced him to the Vatican, but the Roman Curia responded, "Angelelli's work was in complete accord with papal teachings and that "deserved praise and support". ${ }^{159}$ The bishop's opposition persisted against the government, and strengthened after the cleric's refusal "to attend a presidential reception in La Rioja, saying, 'A bishop cannot shake the hand of a man who represses his people."' 160 Following this refusal, Lernoux pointed out, Angelelli assured his death by promoting an "ecumenical group to aid political prisoners and their families after ten of his collaborators were jailed. Later released, the ten took refuge in Angelelli's

\footnotetext{
${ }^{156}$ Lernoux, Cry of the People, 346.

157 Ibid., 346.

158 Ibid., 347.

159 Ibid., 348.

160 Ibid., 348.
} 
home." ${ }^{161}$ In addition, his strong and public declarations exacerbated his enemies. For instance, during a funeral of two priests tortured and murdered by the federal police in La Rioja, the bishop said that they were killed "'to silence the Church, the voice of the voiceless." ${ }^{162}$ In another episode, Angelelli was informed about the detention and torture of Father Francisco Gutierrez, who was accused of "taking boys to the mountains to indoctrinate them." ${ }^{163}$ The bishop went to the detention center to verify the priest's conditions, and according to Morello, Angelelli first reported,

Paco [Francisco Gutierrez] told me that he was tortured but told me not to say anything because they would just torture him more, and so [Angelelli] told Paco "I'm sorry, but I have many lay people in prison here with you and if I say nothing when they torture a priest, what are they going to do to them?"

Then, the bishop asked a soldier about Gutierrez, nevertheless

the soldier in charge denied the torture, but the doctor who brought the bishop confirmed the report. Angelelli told him, "If you put your hands on that priest again, I am going to yell so loudly about it that you're going to be sorry until the day you die." 164

In 1976, Angelelli concluded that "soldiers were suspicious of the Gospel. They didn't understand or accept the teachings of the Council, and by no means

\footnotetext{
161 Ibid., 348.

162 Ibid., 349.

163 Morello, SJ, The Catholic Church and Argentina's Dirty War, 70.

164 Ibid., 72.
} 
the declaration of Medellin." ${ }^{165} \mathrm{And}$ this clearly confirmed in the testimony offered by Quiqley, cited by Smith:

. . . . I remember talking with an Argentine seminarian in 1976 just after the killing of six people. He said that the word "Medellin" couldn't be mentioned, that the word itself had taken on so much political significance that "the Kremlin" was a more neutral term than "Medellin". Medellin had become the symbol of subversion, of communist infiltration. ${ }^{166}$

This declaration accords with my initial premise presented, that the Church was assumed linked to Marxism, the evil. In this vein, it is possible to understand on one hand, the brutal repression against clergy and religious, who Lernoux estimates in Argentina, during 1968-1978, at around 150 victims. ${ }^{167}$ But on the other hand, as Dussel explained, while Angelelli was denouncing and fighting against the regime's human rights violations, most of the Catholic hierarchy in Argentina made an alliance with the military state and the elites. The Archbishop, Pio Laghi, who was by that time the Papal Nuncio to Argentina (1974-1980), was one of the key Catholic leaders in this alliance. After the disappearances of more than 10,000 Argentinians during 1976-83, the prelate "'expressed his conviction that [President Jorge] Videla and other leaders are

\footnotetext{
165 Ibid., 70.

166 Smith, The Emergence of Liberation Theology, 194.

167 Lernoux, Cry of the People, 466.

The sum is the result of: Defamed 19, Arrested 93, Tortured 11, Killed 18, Kidnapped/Disappeared 9, Exiled 2.
} 
good men at heart." ${ }^{168}$ The Mothers of the Plaza de Mayo, a movement for human rights, denounced the prelate, who:

was seen in the clandestine detention centers. He was consulted as to whether prisoners should be spared or killed, and they asked his advice regarding "the Christian and compassionate way to liquidate them." He participated, they charged, actively with the bloody members of the military junta and he undertook personally a campaign designed to hide the horror, death and destruction. He was one of those who governed the country from the shadows. ${ }^{169}$

Even though, there was no legal process against Laghi, he is considered one of the Catholic hierarchy involved in the repression of other Christians, as Mothers of the Plaza de Mayo added:

when Laghi was approached on behalf of "five disappeared Little Brothers of Jesus," he refused to intervene, saying these were people with dangerous ideologies who had infiltrated the church. ${ }^{170}$

In spite of this shameful face of the Church, the Catholic Church side that confronted the military regime and advocated for human rights should be remembered, together with movements such as Mothers of the Plaza de Mayo and Justice and Peace, led by Nobel Prize winner Adolfo Perez Esquivel. ${ }^{171}$

\footnotetext{
${ }^{168}$ Arthur Jones, "Documents Reveal Nuncio's Cautious Human Rights Stance", National Catholic Reporter, August 30, 2002, accessed January 8, 2016, http://natcath.org/NCR Online/archives2/2002c/083002/083002m.htm.

169 Ibid.

170 Ibid.

171 Dussel, La Iglesia Latinoamericana de Sucre a Santo Domingo 1972-1992, 83. (own translation)
} 


\section{Central America}

"Be a patriot and kill a priest! (El Salvador)

During the 1960s and 1980s, El Salvador and Nicaragua were immersed in an extreme socio-economic and political condition. Nicaragua had been under the brutal dictatorship of the Somoza family since $1936,{ }^{172}$ and El Salvador was under a landowner-military regime since the 1930 's ${ }^{173}$ that led to one of the bloodiest civil wars in the region (1980-1992). Under this political oppression, absolute conditions of poverty in contrast to the enormous wealth of a few, were the common reality that placed the zone as one of the most exploited of the region. For instance, in Nicaragua $60 \%$ of the population suffered from malnutrition, 36\% were unemployed, $73 \%$ lived in inadequate housing, and $80 \%$ of the children had no access to education. ${ }^{174}$ Moreover, illiteracy averaged $50 \%$ while in rural areas reached $90 \%$. Similarly, in El Salvador $80 \%$ of children were malnourished and $90 \%$ of the peasants had no land, while $2 \%$ of the population owned $58 \%$ of the arable lands. For these reasons, Catholic priests, nuns and laity committed to the poor, advocated for social and economic justice.

In this regard, since the Catholic Church began to raise consciousness among the neediest, promoted agrarian reform and denounced government abuses, repression against its members intensified. Not surprisingly, the effect of

\footnotetext{
172 Lernoux, Cry of the People, xi.

173 Ibid., 64.

174 Sharon Erickson Nepstad, "Popular Religion, Protest, and Revolt," in Smith, ed., Disruptive Religion: The Force of Faith in Social-Movement Activism (New York, London: Routledge, 1996), 117, 109.
} 
this repression was contrary to the government's goal of defeating Liberation Theology. Indeed, as Crahan points out, "the violence with which the governments reacted to even the slightest hint of reform, radicalized many church-men and church-influenced groups, making them more sympathetic to the arguments of the liberation theologians." 175

\section{El Salvador}

As a matter of fact, by the late 1970s, El Salvador had an anti-Catholic government and Liberation Theology was viewed as a threat. Priests were being expelled, Carlos Romero, Salvadoran presidential candidate at that time promised, if elected, to expel all Jesuits. ${ }^{176}$ Jesuits, since the early 70 s, were supporting peasants in rural zones; such was the case of the agricultural community of Aguilares, where three priests were assassinated together with three peasants. ${ }^{177}$ In this village, people lived in huts where there was no electricity and no running water, among the lack of other basic services. In this scenario, Jesuits taught the peasants to be "agents of change and to seek such fundamental conquests as unions and the defense of labor rights." ${ }^{178} \mathrm{As}$ a result

\footnotetext{
175 Margaret E. Crahan, "Cuba" in Sigmund, ed., Religious Freedom and Evangelization in Latin America. The Challenge of Religious Pluralism (Maryknoll, New York: Orbis Books, 1999), 214 109.

176 Arthur Jones and NCR Staff, "A Look at Declassified State Department Documents" National Catholic Reporter, September 23, 1994. Accessed December 15,2015. http://natcath.org/NCR Online/archives2/1994c/092394/092394v.htm.

177 Lernoux, Cry of the People, 61.

178 Ibid., 70.
} 
of their work, the Jesuits said, "the peasants began to open their ears to the 'Good News' [the Gospel],"179 and they understood that all people were equal in front of God, thus no one must accept to live in conditions of huge inequalities.

As a result, peasants started to organize themselves, joined FECCAS (Christian Federation of Salvadoran Peasants) and demanded better wages, agrarian reform and lower prices. These requests brought repression by landowners, who had the government's backing. The alliance of landowners and the government developed a campaign against the people of Aguilares, including its priests. Peasants suffered persecution, imprisonment and torture, while others were murdered. Salvadoran Jesuit Rutilio Grande, was the leader, whose name was smeared in the vicious campaign. Some priests were expelled and Archbishops Chavez y Gonzalez denied landowners allegations, and supported priests. ${ }^{180}$

The National Catholic Reporter exposed the atmosphere regarding the Salvadoran government's attacks against religious members:

In March, [1977] Jesuit Fr. Rutilio Grande was murdered. In April, two University of Central America professors were arrested. Jesuit Fr. Jorge Sarsane was deported. Then three U.S. priests, Benedictine Fr. John Kevin Murphy and Maryknoll Frs. Bernard Survil and Lawrence McCulloch, were deported. ${ }^{181}$

\footnotetext{
179 Ibid., 70.

180 Ibid., 71-73.

181 Jones and NCR Staff, "A look at declassified State Department Documents" National Catholic Reporter.
} 
Similar to Fr. Rutilio Grande, was the fate of Father Alfonso Navarro Oviedo, a parish priest who taught peasants that God made all people equal. Therefore, landowners, peasants and priests were all the same. This, said a Church leader "came as quite a shock . . . the peasants didn't know what to think." ${ }^{182}$ Landowners rejected the notion that peasants should think at all. That represented a communist-inspired idea to them. But, the real reason behind the rejection is that landowners, "like other privileged minorities in Latin America live in fear that hordes of machete-wielding peasants will one day descend on them, demanding their rights." ${ }^{183}$ As a result, Father Navarro was murdered by an organization called White Warriors Union, a right-wing surveillance group. ${ }^{184}$

The decade of the 1980s began, and Jesuits continued to be under attack in El Salvador and Guatemala. Regarding the Jesuit threat, the S.J. Fr. Tojelio Pedraz, president of the Catholic University in San Salvador, answered to an Italian journalist, when asked whether the Jesuits encouraged the guerrillas,

There are only 32 Jesuits in this country. Four of them are over 90 , and one is sick. So the idea that 27 priests are capable of causing a social revolution is all too flattering. ${ }^{185}$

On the other hand, in February 1980, facing the escalating violence, San Salvador's Archbishop Oscar Romero wrote to President Jimmy Carter asking

\footnotetext{
182 Lernoux, Cry of the People, 75.

183 Ibid., 75.

184 Ibid., 75.

185 Arthur Jones and NCR Staff, "A Look at Declassified State Department Documents" National Catholic Reporter.
} 
him to not approve aid to the Salvadoran military. In this message, the Archbishop also expressed his concern about the U.S. military that had been training the Salvadoran Army and its systematic violation of human rights:

In the last few days news has appeared in the national press that worries me greatly: According to the reports, your government is studying the possibility of economic and military support and assistance to the present junta government. Because you are a Christian and because you have shown you want to defend human rights, I venture to set forth for you my pastoral point of view. ... I am very worried that the government of the United States is studying a form of abetting the army of El Salvador by sending military teams to "train three Salvadoran battalions in logistics, communications and intelligence." If this information is correct, the contribution, instead of promoting greater justice and peace in El Salvador, will without doubt sharpen the injustice and repression against the organizations of the people, which repeatedly have been struggling to gain respect for their most fundamental human rights.

The present junta government and above all the armed forces and security forces unfortunately have not demonstrated their capacity to resolve, in political and structural practice, the grave national problems. In general, they have only reverted to repressive violence producing a total of deaths and injuries much greater than in the recent military regimes whose systematic violation of human rights was denounced by the international committee on human rights. ${ }^{186}$

A month later, Archbishop Romero was murdered, while he was conducting a mass. The State Department synopsis stated, that the Catholic Archbishop "Romero was reportedly targeted because of his public stance

\footnotetext{
${ }^{186}$ Arthur Jones and NCR Staff, "A look at declassified State Department Documents" National Catholic Reporter.
} 
against the death squads and his call for peace." ${ }^{187}$ In December of the same year, four U.S. sisters were raped and murdered.

This case was particularly controversial since the victims were U.S. citizens as well as sisters, and an outrage grew over Carter's military aid and consequent human rights violations in El Salvador. There were internal political conflicts, thus conservatives and religious groups counteracted, under the context of Carter-Reagan presidential transition. In this regard, the National Catholic Reporter printed some accusations from the Council for Inter-American Security, a group in favor of the Reagan's foreign policy, which said,

the religious women "may have been working with left-wing guerrillas to overthrow the government." The council offered no proof for the charge except that "all but one of the murdered women were members of the Maryknoll Society, which has earned a reputation for championing radical politics and liberation theology." 188

In the same way, the National Catholic Reporter analyzed declassified State Department documents, where churchwomen were linked to communists groups. The article reported,

The Reagan nominee for the State Department's human rights bureau, Ernest Lefever, said the nuns "used religion as a garb for cloaking political activity" and "hiding guns for the insurgents" . . . . Jeane Kirkpatrick, U.S. ambassador to the United Nations, said, "The nuns were not just nuns, they were political activists, and we should be very clear about that." ${ }^{" 189}$

\footnotetext{
187 Ibid.

188 Ibid.

189 Ibid.
} 
It is important to note, that during the Reagan administration, the U.S. military aid increased to El Salvador contrary to Archbishop Romero's request to former president Jimmy Carter. Moreover, Budde informs that in 1980, foreign policy members of the entering Reagan's administration released the document "A New Inter-American Policy for the Eighties," later known as the Santa Fe Statement, where it was suggested that opposition against Liberation Theology must be part of the U.S. policy in Latin America. The statement also "charges that liberation theologians "use the church as political arm against private property and productive capitalism," and it recommends countermeasures." 190 Later in 1984, the Inter-American Security Council issued Santa Fe II, which "urged the president [Reagan] to establish links with conservative sectors of the Catholic Church and continue efforts against liberation theology." 191

In the same token, in 1984, in a declassified document from The National Bipartisan Commission on Central America, its chairman Henry Kissinger stated:

The Commission recommends that the United States provide to El Salvador ... significantly increased levels of military aid as quickly as possible, so that the Salvadoran authorities can act on the assurance that needed aid will be forthcoming. The training and improvement of the Salvadoran forces to the point where they can effectively wage counter-insurgency will take time. ${ }^{192}$

\footnotetext{
190 Michael L. Budde, The Two Churches: Catholicism and Capitalism in the World System (Durham, NC and London: Duke University Press, 1992), 46.

191 Ibid., 46.

192 Henry Kissinger, "Report of the National Bipartisan Commission on Central America, January 10, 1984." Accessed June 10, 2015. CIA-RDP86M00886R001200340040-1. CIA Records Search Tool (CREST), National Archives and Records Administration, College Park, MD,102.
} 
Once the government had the U.S. military aid, violence rose, and the National Catholic Reporter described the conflictual ambience,

Communist plots, socialism, Marxism and revolution were the foundation of the era's right-wing and reactionary politics. El Salvador was made to pay a bigger price -- at least 70,000 dead -- during the 1980s, when the United States and Soviet Union were playing out their final Cold War battles, than either superpower was prepared to pay.

In November 1989, military troops invaded the Jesuit residence in San Salvador, killing six priests, together with the housekeeper and her daughter. ${ }^{193}$ Originally from Spain, Jesuit Fathers Ignacio Ellacuría, Ignacio Martin-Baro, Juan Ramon Moreno, Segundo Montes and Amando Lopez had spent decades working in El Salvador and Central America. Soldiers attacked them while shouting "Satanas,[satan]", ${ }^{194}$ and after the massacre, they left a message, "The FMLN [Farabumdo Marti National Liberation Front] executed the Opposition Spies. Victory or Death. FMLN."'195

Similarly, in Guatemala, according to Smith, the police seized the Bible of Christians, and murdered those owners who had underlined some passages from the book of Exodus or the Old Testament prophets linked to Liberation Theology ideas. ${ }^{196}$

\footnotetext{
${ }^{193}$ Arthur Jones and NCR Staff, "A Look at Declassified State Department Documents" National Catholic Reporter.

194 Phillip Berryman, Stubborn Hope: Religion, Politics, and Revolution in Central America (Maryknoll, New York: Orbis Books and New Press New York, 1994), 1.

195 Ibid., 1.

196 Smith, The Emergence of Liberation Theology, 194.
} 


\section{Nicaragua}

In the same fashion, in Nicaragua, land, social justice and violence were the base of conflicts between the Church and the government. The Somoza's family not only led the cruel dictatorship during more of four decades, but also "owned 8,260 square miles, or more than 5 million acres, an area approximately the size of El Salvador."197Moreover, the family controlled the industrial sector, owning more than twenty of the country's biggest companies. Also, the elitegovernment's farms spread north towards the Pacific, expulsing peasants of their land. These expulsions were ushered by a fierce military campaign alleging that peasants were collaborating with guerrilla movements such as the Sandinista National Liberation Front, FSLN for its Spanish acronym. Displaced peasants settled in Zelaya, an eastern jungle and rainforest zone of the country. Somoza's family did not have interest in this area, nonetheless the government placed a repressive surveillance with the pretext of communists and subversive agents. As a result, by the late 1970s, some "six hundred peasants in Zelaya had been killed by government forces"198, as the Capuchin missionaries said.

The country was immerse in violence, and Dodson pointed out, cited by Smith, that the zones under major fighting and resistance were those with BECs organizations. He continues:

The FSLN . . . found the work of organizing people in the insurrection to be much easier in areas where [BECs] were firmly rooted. These institutions of religious inspiration were, in

\footnotetext{
197 Penny Lernoux, Cry of the People, 82.

198 Ibid., 83.
} 
short, effective vehicles of grass-roots political action in the revolutionary setting of the popular insurrection. ${ }^{199}$

With this in mind, Liberation Theology movement was linked to the revolutionary process; since the BECs were fundamental cells for pastoral work and raise consciousnesss, seen as subversive groups. But at the same time, it became the target of the contras, the opposing group to the Sandinista regime, supported by the Ronald Reagan administration. As a result, laity, nuns and priests were victims of repression, imprisonment, torture and murder. Religious members working in Managua slums were in the government's blacklist since teaching the poor their legal rights was against Somoza preference for "uneducated oxen". 200 The government banned Catholic schools and their courses in humanities were considered subversive. In the same vein, those who strongly denounced government atrocities were threatened and accused of treason. This is the case of Father Fernando Cardenal who testified about human rights violations in Nicaragua before the U.S. House Sub-committee on International Organizations. Another case was Fernando's brother, Ernesto. Ernesto Cardenal spoke up in Washington against the regime, and published the Gospel of Solentiname, considered "to be one of the most damming denunciations of the Somoza dynasty ever printed." ${ }^{201}$ Fathers Ernesto y Fernando Cardenal along with Edgar Paralles y Miguel D'Escoto assumed

\footnotetext{
199 Smith, The Emergence of Liberation Theology, 227.

200 Penny Lernoux, Cry of the People, 90.

201 Ibid., 90.
} 
political positions in the Sandinista regime trying to maintain the Christian influence, but political roles placed them against the Church itself.

On the other hand, Nicaragua experienced strong tensions between the Sandinistas and the Catholic Church, and regardless Cardinal Obando y Bravo's demands, the situation got worst with the expulsion of 10 priests in 1984, and a bishop in $1986 .{ }^{202}$

\section{Conclusion}

In this chapter, I have approached political repression against Liberation Theology, and church workers in Latin America during the late 1960s to 1990s. Military governments and dictatorships, under the National Security Doctrine, identified Liberation Theology as a subversive agent linked to Communism. For that reason, laity, nuns, priests and followers of Liberation Theology suffered persecution, exile, imprisonment, torture and murder. The establishment of powerful transnational security organizations such as Operation Condor and Plan Banzer, successfully developed an anti-communist crusade across the region, including the progressive Catholic Church and Liberation Theology as the target of their goal. As can be seen, repression against the liberationist movement increased and spread in Latin America, because it was not possible to distinguish the two projects I mentioned at the beginning. On the one hand, the political and military project carried out the anti-communist crusade

202 Andrew J. Stein, "Nicaragua" in Sigmund, ed., Religious Freedom and Evangelization in Latin America. The Challenge of Religious Pluralism (Maryknoll, New York: Orbis Books, 1999), 214, 180. 
in the region. And, on the other hand, the religious project for social justice and human dignity focused on the preferential option of the poor.

\section{Chapter 3}

Religious and Social Opposition to Liberation Theology

In this chapter, I tackle the religious and social opposition that arose against the progressive Catholic Church and Liberation Theology in Latin America, as a result of the impact of the Second Vatican Council and the Medellin's instructions since 1968. In this vein, I will approach the expansion of Liberation Theology and the emergence of religious opposition to the liberationist movement, as a consequence of divisions within the Catholic Church. Likewise, I will present the case of religious opposition supported by external funds, to then finally advance towards the social opposition against Liberation Theology and the proliferation of Protestant sects in Latin America.

\section{Religious Opposition}

\section{Second Vatican Council}

The Second Vatican Council (1962-1965) made a call to action for Christians facing social injustice and human development under the context of modernization and the Cold War, as I have mentioned in the Introduction. The Second Vatican Council documents such as Gaudium et Spes, Joy and Hope (1965) and Lumen Gentium, Light of the Nations (1964), in addition to later encyclical Populorum Progressio, The Development of Peoples (1967), promoted 
modern ideas to guide the Church and the whole Catholic community through the challenges of modern times. These documents, following the Gospel's message of love, invited Christians to fight for human dignity and spread a message of peace through justice and the development of peoples. The Latin American Catholic Church welcomed Vatican teachings through Medellin's work, which adapted the new instructions to the Latin American reality and fostered the ideas of Liberation Theology. As a result, "transformations varied according to the peculiarities of each Church and each national political context,"203 and, in most of the cases, those transformations had to endure and confront religious opponents. This was particularly the lot of the progressive sector of the Church, as I will explain later.

In Brazil, during the 1960s and 1970s, Dom Helder Camara - a pioneer of the progressive thinking and Liberation Theology ideas - was the subject of constant defamation campaigns and attacks from the conservative Catholic wing. Dom Helder, in his commitment to the poor, developed educational and pastoral programs and encouraged people to work for better life conditions. In an environment of extreme conditions of poverty, social injustice, and human rights violations, Dom Helder continually denounced landowners' repression against peasants and the abuses of government. He was considered a communist because of his concerns about social justice and land reform. For this reason, he said, "when I feed the poor they call me a saint; when I ask why they are poor

\footnotetext{
203 José María-Guio, "The Latin American Church in the Wojtyla's era New Evangelization or Neo-Integralism," Kellogg Institute 159 (1991):3, accessed January 20, 2016, http://kellogg.nd.edu/publications/workingpapers/WPS/159.pdf.
} 
they call me a Communist." ${ }^{204}$ But Dom Helder, not only had opponents from the conservative priests and the government as I mentioned in chapter 2, but also from social conservative groups supported by clerics. According to Jesuit Jeffrey Klaiber, this was the case, for example, of Tradition, Family, and Property (TFP), which was a Catholic conservative organization. TFP steadily denounced Dom Helder and other progressive Catholics as subversives and communists. The Jesuit remarks, that in 1968, TFP organized a campaign to collect signatures -$1,600,000$ total -- against the communists in the church. It is said that conservative clerics such as Dom Gerlad Sigaud and Dom Antonio Castro Mayer signed as well as ministers and important military. ${ }^{205}$ Yet after he had travelled around the world denouncing human right violations during the Brazilian military dictatorship (1964-1985), Dom Helder was nominated to the Nobel Peace Prize, and finally the Vatican, responding to requests by government and conservative bishops, asked the Archbishop to limit his activities to within his diocese in order to silence his voice.

In Colombia, as theologian Enrique Dussel reveals, the Second Vatican Council did not deeply influence the Catholic Church in terms of progressive changes. ${ }^{206}$ This could be the result of the early death of sociologist and Catholic Father Camilo Torres, who came from a conservative and oligarchical family and

\footnotetext{
204 David Regan, Why Are They Poor? Helder Camara in Pastoral Perspective (Münster: Lit Verlag, 2002), 7.

205 Jeffrey Klaiber, S.J., The Church, Dictatorships, and Democracy in Latin America (Maryknoll, NY: Orbis Books, 1998), 28.

206 Dussel, La Iglesia Latinoamericana de Sucre a Santo Domingo 1972-1992, 93.
} 
joined the Colombian guerrillas. In 1966, Torres died in his first encounter with the military. ${ }^{207}$ As Bidegain mentions, the Colombian Bishops were not able to properly handle Torres' political activities and his concerns for the extreme poverty and socio-economic conditions in his country. Torres' political activism was the result of his experiences through pastoral action, youth working groups and his commitment to radical social changes. He pointed out the passive attitude of the Catholic hierarchy facing the crisis of the poor, versus its support for the dominant elites. ${ }^{208}$ These were some of the reasons that took Camilo Torres to his radical decision.

Early in his path, Camilo Torres, thanks to the modern visions of Cardinal Crisanto Luque from Bogotá, had been sent abroad to study Sociology: ${ }^{209}$ experiences that provided him with wide and contemporary views of the modern times. According to Lernoux, he, similar to his Louvain colleague Gustavo Gutierrez, was experiencing "an intellectual flowering, caused by the crossbreeding of the social sciences and theology, that had far-reaching consequences for Louvain's Latin American students." ${ }^{210}$ But contrary to Gutierrez, Torres was more a doer than a thinker, and after analyzing Christian commitment in his country, along with the political and economic reality "without

\footnotetext{
207 Ibid.,93.

208 Ana María Bidegain, Historia del Cristianismo en Colombia. Corrientes y Diversidad (Bogotá: Taurus, 2004), 361-362.

209 Ibid., 357.

${ }^{210}$ Lernoux, Cry of the People, 29.
} 
the rose-colored glasses supplied by the Alliance of Progress," ${ }^{211}$ he fatally took up arms.

As Dussel affirms, his death caused a crisis within the Catholic Church. In Latin America, Torres' death spread tremors within the institution, which was unready to handle the paradoxical guerrilla-priest phenomenon. Some sectors of the Church began to mistrust priests' engagement with the poor and social justice, linking their actions with guerrillas and communists groups. In Colombia, the most conservative nation in the region, the Episcopate expelled the directors of El Catolicismo (The Catholicism) magazine, and rejected the base document of the Medellin Conference (1968). ${ }^{212}$ However, CELAM, led by a progressive group of bishops, assumed the commitment for the poor from Medellin's instructions, following Vatican teachings, and established pastoral and action plans to pursue its goal. In this way, CELAM taught and sponsored courses in Liberation Theology during 1968-72. Later, however, the conservative episcopal wing, led by Colombian Bishop Alfonso Lopez Trujillo, took over CELAM and condemned the Liberation Theology movement. ${ }^{213}$

\footnotetext{
$211 \mathrm{Ibid} ., 29$. Alliance of Progress was a program launched by the Kennedy administration, whose "stated goals were to promote development and contain communism, and few then realized the ambiguities contained in that statement. Only later was it learned that development, as practiced, benefited the rich at the expense of the poor, and that containment of communism was often simplistically equated with protecting an unjust and un-Christian status quo." (Ibid., 284)

212 Dussel, La Iglesia Latinoamericana de Sucre a Santo Domingo 1972-1992 , 93.

${ }^{213}$ Smith, The Emergence of Liberation Theology, 170.
} 


\section{Expansion of Liberation Theology}

Nonetheless, before religious opposition developed, there was initial national and continental support to implement new pastoral strategies in light of the commitment to the poor. In this regard, as Smith pointed out, "with this combination of support [national and continental], temporary as it may have been, the political opportunity available to the liberation theology movement could hardly have been greater." ${ }^{214}$ Henceforth, after 1968, the Liberation Theology movement strengthened by integrating into previous Catholic movements, such as "national priest groups, Catholic Action movements, and radical pastoral workers," ${ }^{215}$ which reunited in the emergent current. Soon, CELAM developed training courses and seminars across the region, having as facilitators theologians such as Enrique Dussel, Gustavo Gutierrez, Jose Marins, Segundo Galilea, Jose Comblin and Juan Luis Segundo among others. In addition, the official Church organization established a training program to propagate Base Ecclesial Communities (BECs), which Medellin identified as the "initial cell[s] for building the church and the 'focal point for evangelization." ${ }^{216}$ For this task, Brazilian Father Jose Marins and Colombian Priest Edgar Beltran were in charge of travelling across the region, providing the BECs' ideas and methodology. ${ }^{217}$ Likewise, progressive bishops Leonidas Proaño

\footnotetext{
214 Ibid., 167.

215 Ibid., 170.

${ }^{216}$ Berryman, Liberation Theology, 67.

217 Ibid., 67.
} 
from Ecuador and Panamanian Marcos McGrath led the educational programs in the region, through the Pastoral Institute of Latin America (IPLA) in Quito, Ecuador, the Liturgical Institute of Medellin, Colombia and the Catechetical Institute of Santiago in Chile. This educational network, sponsored by CELAM, was an instrumental key for the expansion of Liberation Theology. It is said that by the late 1960 s

[a]nd over a period of five years, Roman Catholics all over Latin America were being exposed to the message of liberation theology .... . Through the retraining seminars for priests and sisters, the social education conferences for bishops, the work of Marins and Beltran in promoting BECs, and the itinerant programs of IPLA, the membership of the liberation theology movement was rapidly expanding. ${ }^{218}$

After this successful expansion, the temporary period of grace for Liberation Theology was soon curtailed and, in 1972, at the meeting of CELAM in Sucre, Bolivia, conservative bishops organized a determined opposition against the progressive clerics.

\section{Opposition to Liberation Theology and Church Divisions}

During CELAM elections in 1972, conservative and moderate bishops replaced the bishops linked to the Liberation Theology movement. Colombian Bishop Alfonso Lopez Trujillo, the elected secretary of the CELAM, "immediately purged the organization's staff of anyone with ties to liberation theology, including

\footnotetext{
${ }^{218}$ Smith, The Emergence of Liberation Theology, 172.
} 
such distinguished theologians as Enrique Dussel." ${ }^{219}$ Lopez Trujillo also closed down the pastoral institutes mentioned earlier and left just one center in Colombia, where the CELAM headquarters was, so it could be easily controlled. Moreover, the impetus to oust Liberation Theology from the Latin American organization, made the board replace progressive theologian-teachers with conservative instructors. Basically, it was a battle of Catholics against Catholics, the face of religious repression within the Church.

A moderate sector of the Catholic Church which four years before had backed the progressives was feeling unsettled by the radical changes and rumors of Rome's uneasiness over the pace of changes, and so was now backing the Lopez Trujillo's conservative wing. A considerable group of conservative Latin American bishops stood by the prelate, who, in addition, obtained aid from German bishops, through the collaboration of the Belgian Jesuit Roger Vekemans. This cooperation and the anti-Liberation Theology duumvirate Lopez Trujillo-Vekemans, will be elaborated later in this research.

Backtracking to the changes within the Catholic Church, Lernoux explained how the moderates became spooked:

[t]he religious rebellion gave the bishops a sharp jolt, and, under the influence of the conservatives among them (particularly the Colombians, who had raised the lone dissenting voice at Medellin), they began to worry about what they had wrought. The idea that Marxist analysis had been used by CELAM theologians and sociologists to reach some Medellin conclusions was particularly galling - and confusing. ${ }^{220}$

\footnotetext{
219 John L. Allen Jr., "These Paths Lead to Rome. National Catholic Reporter.

220 Lernoux, Cry of the People, 44.
} 
In this confused environment within the Church related to the use of Marxist analysis, CELAM's leader, Lopez Trujillo, published in 1975 his book Liberación o Revolución?, which was translated into English in 1977 as Liberation or Revolution?. His book represented a public denounciation of Liberation Theology, and a tool to spread his campaign against the movement both within the region and outside Latin America. In Lopez Trujillo's publication it is possible to identify, on one hand, the anti-Liberation Theology analysis when the prelate accused the movement of presenting only an ambiguous and fashionable proposal of liberation. In this line, his work revealed that Lopez Trujillo was apprehensive of Liberation Theology when he hoped that it:

does not imprison some people when making an interpretation of the Gospel of the Church, of theological reflection, comparable to the manner in which an octopus imprisons its victim with its tentacles softly and flexibly and finally in a viselike [sic] grip. ${ }^{221}$

On the other hand, I perceive that Lopez Trujillo's work, even though it rejects the movement because of its involvement in politics and Marxist analysis, it also exposes some contradictory Church positions. For instance, Lopez Trujillo accuses progressive priests of getting involved in politics, but at the same time, he says that politics has two connotations, "one is the meaning of politics, as related to the common well-being with all the requirements of favorable circumstances for justice; and the other... . which is related to power or

\footnotetext{
${ }^{221}$ Alfonso Lopez Trujillo, Liberation or Revolution? An Examination of the Priest's Role in the Socieconomic Class Struggle in Latin America (Huntington, IN: Our Sunday Visitor,Inc, 1977), 75.
} 
authority." ${ }^{222 H a v i n g ~ h i s ~ d e f i n i t i o n ~ o f ~ p o l i t i c s, ~ I ~ h a v e ~ s e e n ~ t h a t ~ L i b e r a t i o n ~ T h e o l o g y ~}$ proposed a religious project from the former concept, to pursue social justice and common well-being inspired by the Gospel. But, Lopez Trujillo, in turn, supported the latter concept when he says that

it is obvious that the neutrality of the Church concerning a wide conception of politics, as related to the common good, cannot be other than its neutrality facing a more strict sense of the term, referred to its specific goal: power. ${ }^{223}$

Having this statement, it seems to me, that Lopez Trujillo critiqued Liberation Theology to get involved in politics, but he also brings up a political role of the Church. He favored neutrality and power over supporting changes to pursue social justice, when he says that the Church should not "abandon its neutrality and become a promoter of new systems." ${ }^{224}$ In this sense, neutrality and power could lead the Church to support some existing Latin American governments despite the injustice they preside over. For instance, similar to Lopez Trujillo's stand, there were other prelates who took conservative and ultraconservative stands, even backing military regimes. For example, early in 1973 , the Chilean Church's neutrality turned into cooperation with the Pinochet military coup against Allende due to the absence of official Church pronouncements, as Fernandez remarks. ${ }^{225}$ The author cites Father Joan Alsina, assassinated by the

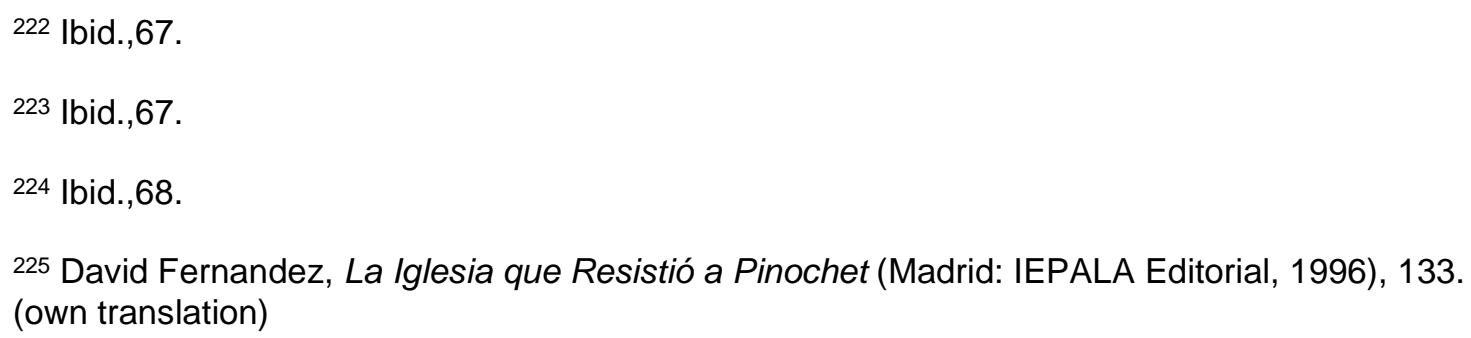


military coup, who rejected the Church's claim of neutrality, saying that equilibrium only works during peace times. ${ }^{226}$ Similar, was the case of Chilean Bishop (Cardinal as of 1988) Jorge Medina Estévez, who was a strong Pinochet supporter. During the transition from Pinochet's regime to a democratic system, the Cardinal said on Aug 3, 1990, "'[t]he fact that democracy exists does not automatically mean that God would want it to be put into practice."'227 Later, in 1999, facing the possible extradition of former Chilean dictator General Augusto Pinochet, Cardinal Medina declared that "I've prayed and prayed for Senator Pinochet as I pray for all people who have suffered;"228despite clear and wellknown evidence that during the 17 years of Pinochet's regime there were thousands of murders and disappearances. Medina Estevez was one of the enemies of Liberation Theology, as well as Italian Cardinal Angelo Sodano, who served as papal nuncio in Chile and supported the Pinochet dictatorship. Sodano was responsible for organizing a successful religious repression in the church through its team of conservative bishops including:

Antonio Moreno of Concepción, who forbade priests and nuns to take part in public protests against Pinochet, even if their role was simply to lead prayers. Moreno also led an investigation into a seminary accused of allowing its students to take part in protests .... [And] Pablo Lizama of Melipilla, a former police chaplain, who said his pastoral concern was for military personnel alienated from the church because of its criticism of human rights abuses. ${ }^{229}$

\footnotetext{
226 Ibid., 133.

227 John L. Allen Jr., "These Paths lead to Rome”, National Catholic Reporter.

228 Ibid.

229 Ibid.
} 
Another example of ultra-conservativism was the Argentinean hierarchy, where the majority supported the military regime and its brutal repression (19761983). As Finchelstein reveals, only four clerics of more than 80 members of the Episcopal Conference publicly denounced the illegal repression: "clerical fascism was an active part of the dictatorial repression."230 Finchelstein cites Nobel Prize winner Adolfo Pérez Esquivel: "'the Archbishop of Paraná province, Monsignor Adolfo Tortolo...justified torture, except the use of electric shocks,' which he deemed a waste of electricity."231Tortolo believed that communism was a virus, and repression would purify the Church and Argentinean society. As a result, the bishop, who was the head of the Episcopal Conference by that time, "kept his diocese $(\ldots)$ like a fortress that protected itself against the changes emanating out of the Council."232 On this idea of purifying the Church, Morello for his part, presents an interesting point that explains why in Argentina Catholics tortured Catholics. He mentions that during the interrogations of Vicar Esteban Inestal, and two laypeople, directors of the Rural Movement, the soldiers told them that John XXIII and Paul VI were the ruin of the Church, and that the Church of La Rioja [province of Argentina] was separated from the Universal Church. ... In the military's thinking, these two pontiffs had betrayed the Catholic faith. ${ }^{23}$

\footnotetext{
${ }^{230}$ Federico Finchelstein, The Ideological Origins of the Dirty War. Fascism, Populism, and Dictatorship in Twentieth Century Argentina (Oxford, New York: Oxford University Press, 2014), 130.

231 Ibid., 130.

232 Klaiber, S.J., The Church, Dictatorships, and Democracy in Latin America, 78.

${ }^{233}$ Morello, SJ, The Catholic Church and Argentina's Dirty Wa , 70.
} 
Dussel noted the additional conflict over the Latin American Bible and the Argentinean Episcopate's stand on it. The ultra conservative, Monsignor Idelfonso Sandierra, stated that the Latin American Bible edition included plenty of Marxism and subversive principles. The government supported him and sanctioned the Christian publishing companies, Ediciones Paulinas and Editorial Claretiana. ${ }^{234}$

Thus, it is not difficult to understand why, particularly in Argentina, the repression against progressive priests, religious members and Liberation Theology followers was particularly fierce.

In like manner, in Brazil, the bishops aligned with the military regime were Dom Castro Mayer, Archbishop Sigaud, ${ }^{235}$ and Cardinal Rossi, who constantly celebrated masses praising the 1964 military coup, as Klaiber exposes. ${ }^{236}$ In Uruguay as well, the Catholic hierarchy supported the military, such as Father Antonio Corzo, an anticommunist militant, and Jesuit Bishop Carlos Mullin, who was a close friend of the dictator Juan Maria Bordaberry. ${ }^{237}$ According to Morello, this kind of Catholicism was focused on preserving the hierarchical structure of the institution and its power, rather than pursuing pastoral work among the believers. ${ }^{238}$

\footnotetext{
${ }^{234}$ Dussel, La Iglesia Latinoamericana de Sucre a Santo Domingo 1972-1992, 78.

235 Ibid., 442.

236 Klaiber, S.J., The Church, Dictatorships, and Democracy in Latin America, 26.

237 Ibid., 113-155.

${ }^{238}$ Morello, SJ, The Catholic Church and Argentina's Dirty War, 182.
} 
With this in mind, it is important to understand the hostile environment within the Catholic Church, with a leadership turning to the conservative wing. As a result, there were ideological issues that were dividing the Latin American Church, leading to a lack of unanimity and mainly two Church's stands as Lernoux suggests,

If it [the Church] is a servant of the people - and the majority of the people in Latin America are poor - it must take the side of the poor and be poor itself. But if it is a representative of power, concerned primarily with institutional survival, it must help preserve what prevails: any talk of a people's socialism or an alternate economic system threatens existing structures. ${ }^{239}$

Considering these contrary positions, it is possible to straightforwardly comprehend the confrontation within the Church, and the opposition against Liberation Theology. Moreover, I would say that each sector of the Catholic Church, from its own perspective, defended its vision. In other words, and in order to better understand some Church currents, there is the ultra-conservative group linked to the military that sought to maintain its power and its hierarchal structure. Then, there is a group of conservatives and moderates aligned with social action, as for example the Church that promoted the General Catholic Action, but who were unwilling to directly confront the state or economic elites. And then, there is the Church of the poor, the one committed to the most needy, fostered by Pope Paul VI and repressed by Pope John Paul II.

Once conservative Lopez Trujillo assumed his role at CELAM, a crusade against liberationists became distinctive of the 1970s -1990s in Latin America,

${ }^{239}$ Lernoux, Cry of the People, 413. 
with the Vatican's support. The Vatican, even though it had delivered a message of human dignity and commitment to the poor, also had to defend its hierarchical structure, and save the Church from Communism. For this reason, the Vatican's rejection against progressive religious strengthened.

In 1979, at the third General Conference of the Latin American Bishops held in Puebla, Mexico, twenty-two liberation theologians ... were not admitted to the heavily guarded seminary ... but they were in direct contact with the progressives within, and were able to react immediately to all developments with position papers that the progressives circulated within the meeting. ${ }^{240}$

The CELAM hierarchy's rejection of the liberation theologians was not an isolated occurance. Sigmund mentions that Pope John Paul II on the plane to Puebla's meeting told to the New York Times reporter,

Liberation theology is a true theology. But perhaps it is also a false theology because if it starts to politicize theology, apply doctrines of political systems, ways of analysis which are not Christians, then this is no longer theology ...Theology of liberation but which one? 241

As Berryman affirms, John Paul II and his Polish perspective about Marxism inevitably put him in conflict with Liberation Theology, which he linked to communism. Besides, having German Cardinal Joseph Ratzinger, conservative and anti-communist, as Prefect of the Congregation of the Faith, the Vatican sought to delegitimize the liberationist movement and restore hierarchical

\footnotetext{
240 Paul E. Sigmund, Liberation Theology at the Crossroads: Democracy Or Revolution? (New York: Oxford University Press, 1990),100.

241 Ibid., 100.
} 
discipline. ${ }^{242}$ In this same perspective, Mainwaring also speaks about how the Brazilian nuncio imposed his authority to trump local suggestions regarding the appointing of Bishops for the archdioceses of Porto Alegre and Brasilia in Brazil. ${ }^{243}$ For instance, in 1981, Dom Claudio Collings was assigned to the Porto Alegre jurisdiction, over the prominent and famous progressive Bishop Ivo Lorscheiter, who had been played key roles in the CNBB since the early 1970 s. In the same token, in 1984, the Vatican appointed conservative Dom Clovis Frainer as the new archbishop of Brazilia. And as the author points out, referring to the conservative replacements, they were needed to dismantle the existing ecclesial network addressing some of the following actions, "firing several paid lay leaders, transferring a large number of clergy out of the diocese ... and prohibiting involvement in opposition political activity."244

During John Paul II's papacy, the conservative ecclesial model of the church strengthened. ${ }^{245}$ Moreover, in his quest to restore the hierarchical structure, the Pope particularly favored conservative groups characterized by having sectarian visions of Catholicism, vertical structure and being theologically reactionary such as the "Opus Dei, Communion and Liberation, the Neo-

\footnotetext{
242 Berryman, Liberation Theology, 109.

243 Mainwaring, The Catholic church and Politics in Brazil, 1916-1985, 99-249.

244 Ibid., 249.

245 Manuel A. Vásquez, The Brazilian Popular Church and the Crisis of Modernity (Cambridge, New York: Cambridge University Press, 1998), 101.
} 
Catechuminate and the Legionaries of Christ." ${ }^{246}$ It is important to note, that John Paul II made Opus Dei a personal prelature, which is a special status where the society was answerable to no one within the Roman Catholic Churches except the Pope . . . . No local bishop could discipline or sanction Opus Dei. Overnight Opus Dei became in effect a global movement without specific diocese. ${ }^{247}$

This special recognition to Opus Dei influenced also CELAM leaders. Some moderate clerics thought that by appointing bishops from the organization, they would counteract Liberation Theology, which the testimony of a Peruvian Carmelite priest denies, "[t]hey [CELAM's leaders] can't stop liberation theology; it's too late. They can make all the bishops Opus Dei, but we're the ones with the people and we're not going to change."248 Indeed, Dussel maintains that Lopez Trujillo, secretary of CELAM, worked with Opus Dei in his anti-Liberation Theology campaign. The religious group collaborated in the organization of the Los Andes meeting in 1985 in Chile, ${ }^{249}$ where the clerics issued the Andes Statement. The Andes Statement "denounced liberation theology as a Marxist perversion of the faith, claiming that it advocated a conflict between the 'popular church' and the 'hierarchical church."'250

\footnotetext{
${ }^{246}$ Paul Collins, "Paul Collins' Explanation of his Resignation from the Priesthood," National Catholic Reporter, March 9, 2001, accessed January 17, 2016, http://natcath.org/NCR Online/documents/CollinsREASONS.htm.
}

\footnotetext{
247 David Yallop, The Power and the Glory: Inside the Dark Heart of John Paul II's Vatican (New York: Carrol \& Graf Publishers, 2007), 147.

248 Smith, The Emergence of Liberation Theology, 203.

249 José Comblin, "The Church and Defense of Human Rights," in Dussel, ed., The Church in Latin America 1492-1992, 449.

250 John L. Allen Jr., "The Vatican's Enforcer”, National Catholic Reporter.
} 
Parallel in time was the Vatican's silencing of one of the major proponents of the Liberation Theology, Brazilian Franciscan Priest Leonardo Boff in 1985, because of the publication of his book Church: Charism and Power ${ }^{251}$ where the theologian criticized the Catholic Church structure. He exposed the necessity not only to spread proclamations about human dignity, but also to put them in practice, beginning within the Church. The book's chapter, The Violation of Human Rights in the Church, clearly describes his concerns about practices in the Church, and the contradictions between theory and praxis. In his words,

The purpose of this reflection is to foster a greater and more effective authenticity in the commitment of the local churches to human rights; the contradiction in terms of theory and practice is not found within these churches themselves but in their collision with authority. The prophetic power of these churches must not be weakened. 252

In this statement it is possible to perceive the hierarchical controversy between the local churches and authority, the inconsistency between theory and practice within the Church, and a concern with power. The fact is that because of his book, in May 1985, Cardinal Joseph Ratzinger, the head of the Vatican's Sacred Congregation for the Doctrine of the Faith, sentenced Boff to be silenced for one year. Boff accepted the suspension, and retired to a Franciscan monastery in Brazil. ${ }^{253}$ In an interview published in 2013, Boff remembers that because Roma didn't like his book, he was called to go to the Vatican, where he

\footnotetext{
251 Leonardo Boff, Church: Charism and Power. Liberation Theology and the Institutional Church (Eugene, OR: Wipf \& Stock, 1985)

252 Ibid., 33.

253 John L. Allen Jr., "The Vatican's Enforcer”, National Catholic Reporter.
} 
was seated in the same chair that in which Galileo Galilei and Giordano Bruno were seated during the Inquisition's times. He added, when he was asked why he and Liberation Theology were attacked, he said that because Liberation Theology asked for changes within the Church and in the society, and that was considered Marxist discourse. He continued, that the Catholic hierarchy has both accused them of being allied with Marxists and charged that Liberation Theology was the Trojan horse through which Marxism will infiltrate the Church. In addition, Boff remarked that the traditional hierarchy rejects the issue of change, that it should be poor, participative and allow more presence of laity and women. Boff concluded that there are two Church models -- not two Churches -- presenting two ways of living Jesus's heritage. One model comes from power, dialoguing with power, establishing with power, but paying a high cost. From the alliance with power, the Church is not able to reach the poor and evangelize them; there are only charities and alms. The second Church model comes from the poor with the awareness of being part of Jesus's heritage. This part wants a different world and a different, inclusive Church, where Liberation Theology represented the way to transform the Gospel and the Social Doctrine into vehicles towards social justice and the liberation of the poor. ${ }^{254}$

I would say that the Vatican's attack against Brazilian Franciscan Father Leonardo Boff reveals that the Church's opposition was based more on the institution's hierarchy and interests rather than on faith or theology. As a matter

\footnotetext{
254 José Luis Velicio, "Leonardo Boff: Teología de la Liberación, posted February 7, 2013, accessed January 15, 2016, https://www.youtube.com/watch?v=ke4CJma8G6U (own translation)
} 
of fact, in 1984, Boff pointed out in an interview that he felt the sanction revealed more the Institution's [the Vatican] authority and power, rather than the truth. The theologian remarked that the Church is not scared of the theologians but of the Church of the base [CEBs], which is a new way of being church. The Church of the base represents a community where archbishops descend to the poor. By the mid 1980s, he said there were 150000 base communities in Brazil. And concerning his supposed connection with Marxist ideology, Boff affirms that Marxist analysis was a tool to express the historical processes that took more than $80 \%$ of the Latin American population into extreme poverty. Marxism provided concepts that liberation theologians used in their work, and that is the only possible link of Liberation Theology with Marxism. ${ }^{255}$

Leonardo Boff's suggestions about the Vatican's authority and stand against Liberation Theology were not far from reality. In fact, in 1984, Cardinal Ratzinger, as the Prefect of Congregation of the Doctrine of the Faith, issued the Instruction on Certain Aspects of Theology of Liberation, which was a document that condemned in strong language the religious movement. In the text, Ratzinger argues the ambiguity of the Liberation Theology's message and adds that it "perverts" the concept of the poor as well the function of the Church. ${ }^{256}$ Likewise, the Cardinal claimed that the movement incites violence to

\footnotetext{
255 Birgit Kraatz and Manfred Mueller, "No Soy un Hereje" (Lecturas Dominicales, FIU Green Library, Bidegain and Uran Collection, Box 4A, Folder B), 6. (own translation)

${ }^{256}$ Congregation of the Doctrine of the Faith, "Instruction of Certain Aspects of the Theology of Liberation", August 6, 1984. Accessed January 14, 2016, http://www.vatican.va/roman_curia/congregations/cfaith/documents/rc_con_cfaith_doc_19840806 _theology-liberation_en.htmI, IX-10.
} 
eradicate oppressive conditions, ${ }^{257}$ is a negation of the faith, ${ }^{258}$ and is corrupted by the use of Marxist concepts. ${ }^{259}$ Facing this attack, an important reaction from Latin American theologians and sectors of the Catholic Church, specifically from Brazil, pushed the Vatican to reconsider the issue. ${ }^{260}$ Thus, in 1986, a new Instruction called Christian Freedom and Liberation was released, accepting all biblical interpretations of Liberation Theology. It accepted the theology of the movement but not the politics. That is why the appointments continued to be reactionary. For instance, after Dom Helder Camara, precursor of Liberation Theology, resigned as bishop of his diocese in 1985, the Vatican assigned as his successor José Cardoso Sobrinho to dismantle the church model created by Camara. ${ }^{261}$ According to Father Jose Comblin,

[t]he repression by the present archbishop was very heavy, very violent, very visible. He expelled 14 priests, those who were working on social problems. He dissolved the Pastoral Land Commission, he dissolved the Human Rights Commission, closed the regional seminary. He took a whole series of quite aggressive measures that provoked opposition. 262

Cardinal Joseph Ratzinger, as John L. Allen Jr. reviews, used his power to polarize the Church. That was the case, for example, of theologian nun Ivone

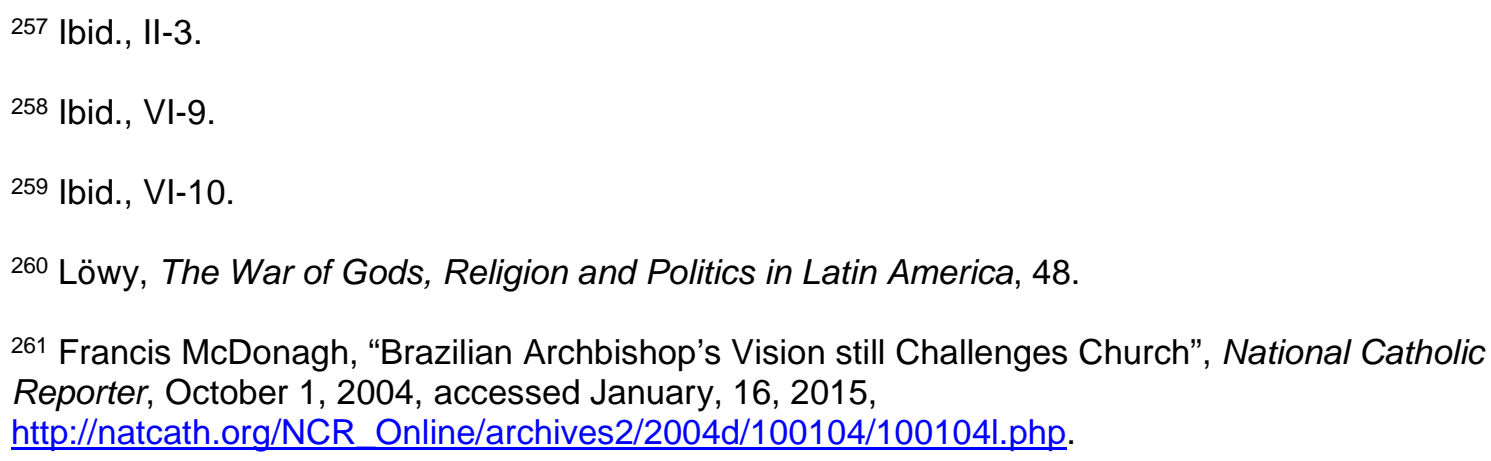


Gebara from Brazil, who was disciplined by Ratzinger because her works linked liberation theology with environmental concerns. It is said that she also was disciplined because she defended poor women who had abortions in order not to endanger existing children. Similarly, the Cardinal restricted Brazilian and progressive Bishop Dom Pedro Casaldiga forbidding speaking trips outside the borders of his diocese. ${ }^{263}$ In addition, by 1991, the Vatican under Ratzinger was ensuring the supremacy of its own authority by taking control of the naming of CELAM's board, contrary to the past when its members made their own selection. Likewise, in the same year, Roman Curial intervention reached the Latin American Confederation of Religious (CLAR) and would have selected their officers, but the meeting was suspended when the members refused the Vatican's imposition. ${ }^{264}$

\section{Religious Repression Supported by External Funds}

Belgian Jesuit Roger Vekemans, a strongly anti-liberation theology priest, received a large amount of funds from the CIA, USAID and the West German bishops in the early 1960 s to promote an anti-communist campaign in Chile. Equally, Vekemans conducted the Centro Bellarmino in Santiago, ${ }^{265}$ and was later accused by the CIA of misspending more than $\$ 400,000$. But the local U.S.

\footnotetext{
263 John L. Allen Jr., "The Vatican's Enforcer", National Catholic Reporter.

${ }^{264}$ Enrique Dussel, "From the Second Vatican Council to Present Day," in Dussel, ed., The Church in Latin America 1492-1992, 180.

265 Patricia Hynds, "The Ideological Struggle within the Catholic Church in Nicaragua," Covert Action, No. 18, Winter 1983, p. 17. Accessed June 9, 2014. CIA-RDP90-00845R0001001800044. CIA Records Search Tool (CREST), National Archives and Records Administration, College Park, MD.
} 
embassy avoided giving Vekemans a negative image because that would fortify pro-communist groups.

As Lernoux mentions, Vekemans' trajectory in Latin America began early in the 1960s, when the Jesuit priest was considered the embodiment of the Church reformer. Vekemans was a polyglot, eloquent and talented in diplomatic relations; hence he created a network of important contributors for his anticommunist religious programs. According to his friend, Jesuit James Vizzard, in 1961, Vekemans also got support also from the Kennedys. After a meeting with John and Robert Kennedy, he boasted: "I got $\$ 10$ millions bucks today- $\$ 5$ million covert from the CIA and $\$ 5$ [million] overt from USAID." ${ }^{266}$ Based on the end justifies the means' principle, he had no problem using the CIA's money to support reactionary Chilean organizations such as the Union of Christian Peasants, the Institute for Union and Christian Training, and the National Association of Farm Workers, among others. He said "I'd take money from the devil himself if it were necessary to stop the communists."267

It is important to point out that Vekemans, with important connections in Europe, played an important role in the transnational religious crusade against Liberation Theology in the region. As Dussel confirms, Vekemans was the driving force behind the anti-Liberation Theology campaign. His campaign encompassed seminars and courses in CEDIAL (Center for the Study of Development and Integration in Latin America), which he founded in 1971 in Bogota, the monthly

\footnotetext{
${ }^{266}$ Lernoux, Cry of the People, 26.

267 Ibid., 27.
} 
publication of the Tierra Nueva magazine, and the organization of congresses to combat Liberation Theology. ${ }^{268}$

Having left Chile after the 1970 election of Allende, the Jesuit priest established himself in Bogota and closely worked with the Liberation Theology's archenemy Bishop Alfonso Lopez Trujillo, who had been the general secretary of the Latin American Episcopal Conference (CELAM) since 1972, as mentioned before. Vekemans received $\$ 200,000$ from the De Rance Foundation, a very conservative American Catholic institution considered "the largest religiously oriented foundation," 269 for his anti-liberation theology book, Teología de la Liberación y Cristianos por el Socialismo (1976). ${ }^{270}$ Also, he was leading the International Institute of the Heart of Jesus, which was one of the major beneficiaries of the De Rance's financial assistance..$^{271}$

\section{Social Repression}

In the presence of Church schisms, at the same time, it has been said that one of the CIA's objectives had been to promote dissent and division within the Catholic Church. As Patricia Hynds maintained in a declassified CIA article, the U.S. government has a long history of political manipulation of religion. She mentions that, as early as 1969, Nelson Rockefeller warned about the danger of

\footnotetext{
268 José Comblin, "The Church and Defense of Human Rights," in Dussel,ed., The Church in Latin America 1492-1992, 449.

269 Hynds, "The Ideological Struggle within the Catholic Church in Nicaragua", Covert Action.

270 John H. Sinclair, "Historical Protestantism" in Sigmund, ed., Religious Freedom and Evangelization in Latin America, 48.

271 Ibid.
} 
the Medellin documents and their preferential option of the poor. He considered that they exposed the Latin American Church to communist penetration. ${ }^{272}$ Of the two different projects in the region, the anti-communist crusade and the preferential option of the poor, for the U.S. government and the U.S. elite, there was only one: the anti-communist fight that saw Liberation Theology as a subversive agent. For this reason, the CIA utilized U.S. Christian missionaries, both Catholics and Protestants, who, acting in accord with patriotic duty, served as informants. Besides, Hynds revealed that the CIA's $\$ 2.6$ billions had been used by Vekemans and other church-related groups to successfully support the 1964 presidential campaign of Eduardo Frei in Chile.

In Chile, the U.S. CIA office also aided the paramilitary organization Fatherland and Liberty, which functioned before and after Allende's election (1970). Likewise, not only in Chile, but also in other Latin American countries the CIA office funded the "right-wing Tradition, Family and Property, which played a role in the overthrow of both Allende in Chile and Goulart in Brazil." ${ }^{273}$ Similarly, in 1975, the U.S. organization backed up the Banzer Plan, which had a clear objective: "to sharpen internal divisions within the Church; to smear and harass progressive Bolivian Church leaders; and to arrest or expel foreign nuns and priests." ${ }^{274}$ Soon, as I mentioned before, other Latin American nations adopted the Banzer Plan, which became a mechanism that repressed and torture many

\footnotetext{
272 Ibid.

273 Ibid.

274 Ibid.
} 
Uruguayan priests in the 1970 s, and sparked tens of murders of religious members in Bolivia and El Salvador. ${ }^{275}$

Supporting Hynds' information are the statements made by Edward Korry, former U.S. Ambassador to Chile from 1967-1971, during administrations of presidents Johnson and Nixon. In his article, The Sell-Out of Chile and The American Tax Payer, ${ }^{276}$ Korry disclosed relevant information about the U.S. strategy against not only Marxism --which was linked to Liberation Theology -but also laicism:

The Kennedys utilized every means - illegal and unconstitutional as well as legitimate - to defeat Frei's Marxist opponent, Salvador Allende. Through the $\mathrm{CIA}$ and other federal agencies, tens of millions of public dollars were spent on Frei's election. So overcome were the Kennedys by their fear of Castro that they even responded with public money to appeal from foreign Jesuits for federal help to combat not only "Marxism" but also "laicism" (a theological term for the widespread Free Masonry movement in Chile) and "Protestantism" (a reference to the American Pentecostal missionaries then swarming across South America). ${ }^{277}$

Korry's article linked the U.S. government to U.S. elite groups in the anticommunist battle in that, during a meeting in 1963, President Kennedy:

persuaded him [David Rockefeller] to organize American big business for the anti-Castro crusade. The banker recruited thirty-seven leading multinationals, such as ITT, [International Telephone \& Telegraph] to form the Business Group for Latin America .... Then the Attorney General Bobby Kennedy ... . systematically integrated members of the same Business

\footnotetext{
275 Pernas, "En dictadura y en democracia."

276 Edward Korry, "The Sell-Out of Chile and The American Tax Payer," Penthouse, March 1978. Accessed June 9, 2014. CIA-RDP09t00207r001000030065-1. CIA Records Search Tool (CREST), National Archives and Records Administration, College Park, MD, 72.

277 Ibid., 72.
} 
Group into CIA programs. As an inducement to Rockefeller, JFK pledged that he would satisfy his request for no-loss guarantees on any future investments in Latin America. ${ }^{278}$

This statement clearly describes the relationship between the U.S. government and the U.S. elites, establishing their anti-communist strategy and attempts to ensure their economic interests in the region.

\section{Protestantism and Pentecostalism}

It has been said that the spread of the Protestant sects has been a "U.S. conspiracy against liberation theology, and more generally against all social movements for the emancipation of the poor." 279 Indeed, for example, Stein, citing the 1969 Rockefeller Report, mentions that there are many Catholic religious members from El Salvador who affirm that the fast proliferation of the Protestants was due to a U.S. government plot, citing also the 1969 Rockefeller Report. Some assure that "foreign missionaries were 'buying' the faith of desperate poor people."280 I agree with these statements, since I found an official document from the Department of State, dated 1987, demonstrating that Liberation Theology was a threat affecting U.S. affairs and that a strategy was needed "to reduce the damage to U.S. interests that liberation theology continues to produce by inciting anti-Americanism and promulgating hostility toward

\footnotetext{
278 Ibid.

279 Löwy, The War of Gods, Religion and Politics in Latin America,113.

${ }^{280}$ Andrew J. Stein, "El Salvador" in Sigmund, ed., Religious Freedom and Evangelization in Latin America,125.
} 
capitalism." ${ }^{281}$ Certainly, one strategy could be through the use of religion; thus, I believe that the U.S. government supported other religious groups to counteract the liberationist movement. In this vein, and since " the USA [was considered] a bastion of godliness and a missionary nation,"282a group of evangelicals were willing to serve the Reagan administration and his foreign policy in Central America. For instance, Colonel Oliver North provided political and military aid with an important participation of evangelicals for the contras during the civil war in Nicaragua. ${ }^{283}$ Colonel North also recruited anti-communist evangelicals to build a politico-religious force that became a "private support network". ${ }^{284}$ This network received funds from:

Pat Robertson's Christian Broadcasting Network, which organized an "Operation Blessing", spending some two millions dollars a year (the well-known tele-evangelist went personally to Honduras to review contra troops); Friends of the Americas, which received a humanitarian award from President Reagan in 1985; the Gospel Crusade, the Christian Emergency Relief Team, Trans World Missions, and other groups of the religious Right, most of them invited, coordinated and briefed by Colonel North. ${ }^{285}$

Besides the Colonel North case, there were many prosperous U.S. evangelical organizations that, in order to captivate the poor, made huge

\footnotetext{
281 U.S. Information Agency,"Liberation Theology and Anti-Americanism: The Challenge to U.S. interests in Latin America,", June 4, 1987. General Records 0306, Research Memoranda 19631999, Entry 64, M-9-17-1986 thru M-3-24-1988, Box 43. National Archives and Records Administration, College Park, MD,1.

282 Löwy, The War of Gods, Religion and Politics in Latin America, 113.

283Ibid., 113.

284 Ibid., 113.

285 Ibid., 114.
} 
donations in charity, social programs, church buildings and disaster relief among others. Similarly, evangelical groups such as the World Vision, through its considerable financing capability, was able to disturb the Catholic base communities, important cells of the Liberation Theology movement. To better understand this World Vision's opposition and its impact in the Catholic believer is through the testimony of Ana María Guacho from the Quechua indigenous community of Ecuador. Guacho is the leader of the Indian Movement of Chimborazo, which was founded by the Ecuadorian liberationist Monsignor Leonidas Proaño, known as the Bishop of the Indias. The indigenous leader affirmed that “'organizing people isn't easy, when World Vision offers money and we offer consciousness-raising."'286Her words speak by themselves. Money puts her at a disadvantage in the context of the BECs, since these did not provide money.

In the same token, and having mentioned the Reagan administration, it is important to point out that according to Kickham, the President belonged to the Full Gospel Business Men's Fellowship International (FGBMFI). This organization is a right-wing Pentecostal association of business and military men created in 1952. Their members believe that they are living in the last days, and that the organization has been chosen "to organize the final harvest, the prelude to the Second Coming of Jesus Christ." 287 The FGBMFI has had a strong

\footnotetext{
286 Ibid, 114.

${ }^{287}$ Larry Kickham, “The Theology of Nuclear War: The Full Gospel Business Men's Fellowship International (FGBMFI)". Covert Action, No. 27, Spring 1987. Accessed June 9, 2014. CIA
} 
presence in zones that have U.S. important interests around the world during the 1980's. In Guatemala for example, Full Gospel member John Carrette, former Army officer in Vietnam, supported and aided the also FGBMFI member General Rios Montt, who became president through an army coup in 1982. In 1986, the organization programmed airlifts for El Salvador and Guatemala, among other countries. ${ }^{288}$

President Reagan was a dispensationalist, which refers to the Biblical prophecies interpretation and the signs of the times. Reagan believed he had a commitment to organize and manage the last days and the Second Coming of Christ. In a conversation with Jerry Falwell during Reagan's presidential campaign, Falwell tells us about Reagan's beliefs:

He told me . . Jerry, I sometimes believe we're heading very fast for Armageddon right now . . . . I am not a fatalist. I believe in human responsibility. I believe that God will respect us for making all-out efforts toward world peace, and that is where my commitment lies. ${ }^{289}$

This statement tells us about Reagan's religious responsibility in his political functions. He had to work for world peace to follow God's commands, and it is important to remember that under the Cold War context the way to pursue peace was fighting against the communism.

RDP90-00845R000100170002-7, CIA Records Search Tool (CREST), National Archives and Records Administration, College Park, MD, 15.

288 Ibid.,17.

${ }^{289}$ Kickham, "The Theology of Nuclear War. Covert Action. 


\section{Conclusion}

In this chapter I have explained the impact of the Second Vatican Council teachings and Medellin documents on the developing of Liberation Theology. The successful expansion of the progressive religious movement across Latin America provoked the emergence of strong religious opposition, as a result of the divisions within the Catholic Church. It has been illustrated how conservative Catholic leaders as Bishop Alfonzo Lopez Trujillo, secretary of CELAM, and Jesuit Roger Vekemans led an anti-Liberation Theology crusade that spread throughout the region to counteract the liberationist movement. Bishop Lopez Trujillo and Vekemans received funds from the CIA and German Bishops among others external collaborators, to support the anti- Liberation Theology cause. Likewise, I have analyzed the powerful opposition from the Vatican, specifically during John Paul II's papacy, having Cardinal Joseph Ratzinger as the Prefect of the Congregation of Faith. In order to counteract Liberation Theology, Pope John Paul II supported conservative groups such as the Opus Dei, replaced progressive bishops and priests with conservative ones, and stopped sending priests to pastoral religious movements such as Catholic Action and BECs. Moreover, John Paul II and Ratzinger banned priests promoters of Liberation Theology, as was the case of Brazilian theologian Leonardo Boff among others. To conclude the chapter, I explained how social opposition against Liberation Theology worked and its influence in the spread of Protestant and Pentecostals groups, particularly in Central America, with the support of the CIA and U.S. Protestant groups. 


\section{Chapter 4}

Opposition to Liberation Theology and Religious Transformation

In previous chapters I have reviewed political, religious and social opposition against Liberation Theology, its proponents, and its Catholic followers. In this chapter I will present how Liberation Theology's repression has led to religious transformation within Christianity in Latin America. For this purpose, I will examine the experiences of individuals and communities who were subjects of different forms of repression -- political, religious or social -- and the religious changes that occurred as a result of such constraint. The opposition to Liberation Theology, instead of extinguishing it, sometimes strengthened it and in other cases changed its form. I found that there is not a unique transformation indeed, religious responses varied.

\section{Changes in the Latin American Catholic Church Following the Repression of Liberation Theology}

After the mid-1980s and early 1990s, the final vindication of the scriptural message of Liberation Theology began with the Vatican second Instruction. Instruction of Christian Freedom and Liberation (1986) accepted Liberation Theology's biblical interpretations, including the central preferential option for the poor, even though in practice, the Vatican discipline against theologians and progressive priests continued as I explained in chapter 3. Finally, in John Paul Il's Letter to the Episcopal Conference of Brazil (April 9, 1986), the Pope 
declared that Liberation Theology was "useful and necessary," 290 as clearly has been demonstrated by the current Pope Francis.

Latin America was gradually experiencing the return of democracy following the intolerable levels of violence under the military regimes, but that democracy was far short of addressing many of the concerns of the poor. Therefore, many issues, such as land reform, education, health care, even the extension of basic utilities to the poor, remained. Some of the worst excesses of capitalism still exist.

In turn, the church remains divided, and is thus unable to take on a strong pastoral. Many Catholics have left the church for different reasons. Some for safety from persecution, and many converted to Pentecostalism, which was a global trend, helped in Central America by American funding - both private and governmental -- of Pentecostals missions. In the same vein, many were disillusioned with religion in general and have turned to secularism, while many others viewed the church as out of touch with modernity, not democratic, as excluding women from ordination/office, and not accepting indigenous cultures, either Indian or African, and their worship's traditions. But some have been in effect, purified by the fire of repression, and become heroes, martyrs, examples of faith and courage who will inspire others. Of course, the same suffering that elevates some spirits to heroism, destroys the very soul of others. Let us review some examples of these religious changes in Latin America.

290 Christopher Blosser, "Towards a Proper Appreciation of Liberation Theology, Some Resources from Pope John Paul II," The American Catholic, December 22, 2009, accessed February 19, 2016, http://the-american-catholic.com/2009/12/22/towards-a-proper-appreciationof-liberation-theology-some-resources-from-pope-john-paul-ii/. 


\section{The Church as a Refuge}

After the Brazilian coup in 1964, when repression intensified against anyone who differed from the regime, the progressive Catholic Church harbored not only Catholics, but also those Christians from different organizations who were being persecuted. Following the politics of the National Security Doctrine as I mentioned in chapters one and two, the military regime eliminated trade, student, and union organizations, censored the press, closed the National Congress, and restricted private and public institutions, as well as the Catholic Church. And even though the government suppressed Catholic radio stations and newspapers, and jailed, tortured and killed religious members, the Church was the unique institution that remained denouncing human rights violations. For this reason, Smith adds, citing Jether Pereira Ramalho:

Repression was generalized in society, so the Catholic Church became a refuge. Political parties and trade unions were abolished. The press was censored. The only institution that had the moral position to fight was the Catholic Church. It became the only space for many people. Later, after the amnesty in Brazil, people moved back into trade unions; but then they were influenced by their time in the Church. 291

In this statement I can perceive, that because of the brutal and illegal repression experienced by Brazilian citizens -- Christian and non- Christians -- a sector of the Church took a stand, and served as refuge for those who were oppressed. It was common to find in penal actions, the repeated justification for the persecution against religious members such as:

291 Smith, The Emergence of Liberation Theology, 193. 
is being verified that they are evangelizing in the light of Marxism or teaching socialism in the light of the Gospel, instead of teaching love toward the Nation, respect toward laws and authorities as it behooves the Church as a recognized, immaculate and eternal institution. ${ }^{292}$

During the military regime (1964-1985), even though the Brazilian court admitted these were not crimes, the fact is that religious and non-religious members suffered torture, imprisonment, persecution and many were murdered in hands of the government's security agents.

Under these circumstances, where the Church became a refuge of the oppressed, I could identify three religious responses. As refugees of the Church, one response is from the Catholics and the second is from the non-Catholics. Then, there is the response from the Church itself. First of all, from the victims' perspective, I believe they found moral support and protection as a way of survival in the Church. They could have chosen a different option knowing that the Church was also considered subversive, a risky place; but even so, they selected to be with the Church. For Catholic victims, in spite the variation in individual religious experiences, the Church's support must have strengthened their faith. This could be possible, as Smith points out from a sociological perspective, because in religious meaning-systems, the experiences of human life have meaning and are not simply mundane, but rather are oriented to the sacred. Thus, as in this case, religion provided a system of beliefs that oriented

292 Catholic Church Archdiocese of Sao Paulo and Joan Dassin, Torture in Brazil: A Shocking Report on the Pervasive Use of Torture by Brazilian Military Governments, 1964-1979 (Austin, TX: First University of Texas Press, Institute of Latin American Studies, University of Texas, 1998), 126. 
people during struggling and suffering circumstances. ${ }^{293}$ In other words, followers perceive that through religion it is possible to overcome earthly circumstances and transcend them from a religious perspective, strengthening their faith.

In turn, for other Christians, it represented an experience to be exposed to different ideas and religious perspectives. That is to say, a situation where diverse systems of thoughts and beliefs intertwine in a dynamic process permeable to new religious ideas. ${ }^{294}$ This confirms the last line of Pereira Ramalho's citation, when it states, ". . . but then they were influenced by their time in the Church." ${ }^{295}$ It suggests to us, that after their experience with the Church, they were not the same; they had obtained different insights. On the other hand, the Church, with some exceptions, took a stand giving them religious and moral response of solidarity and support facing the crisis. I would say that both, the victims and the Church, encountered each other not only to receive and give protection respectively, but also, under repressive circumstances, to look for unity and an opportunity to live. This may be related to Segato's observation, when she says that under social tensions, "selecting companions, making alliances, and seeking identity with a contracted groups of others, while building up, in symbolic terms, an opposition to the social identity of those who are not

\footnotetext{
${ }^{293}$ Christian Smith "Correcting a Curious Neglect, or Bringing Religion Back In," in Smith, ed., Disruptive Religion, 6.

294 Rita Laura Segato, "Religions in Transition: Changing Religious Adhesions in a Merging World," in Jan-Åke Alvarsson and Rita Laura Segato, ed., Religions in Transition: Mobility, Merging \& Globalization in the Emergence of Contemporary Religious Adhesions (Stockholm, Elanders Gotab, 2003), 10-11.

295 Smith, The Emergence of Liberation Theology, 193.
} 
part of it," ${ }^{296}$ is part of choosing beliefs. In this case, I believe that victims of the repression were not looking specifically for a new belief when they joined the Church, but the progressive Catholic Church was the available option, through which they would seek for alliances to overcome the extreme situation and build up opposition against the repressive identity of the government. In other words,

religion could use its relatively privileged position to help keep alive a remnant of autonomy in civil society, to sustain the voice of resistance and to prepare the grounds for a broader social-movement opposition once the authoritarian regime begins to relent. ${ }^{297}$

As I have mentioned before, the Church as a refuge, became the voice of the voiceless, an open space to religious interaction in the mid of the crisis, as the Brazilian Archdiocese of Sao Paulo led by Archbishop Paulo Evaristo Arns and the Archdiocese of Santiago de Chile, with Cardinal Raúl Silva Henríquez.

Nonetheless, contrary to the Church as a Refuge, there were church leaders that took stands supporting the regime or at least were silent about the killings, which I will tackle later in the Inquisitorial Church section.

\section{Religious Transformation within the Catholic Church}

The Church, having simultaneous conservative and progressive trends, also experienced some transformations. It is said, and with some exceptions, that:

\footnotetext{
${ }^{296}$ Rita Laura Segato, "Religions in Transition: Changing Religious Adhesions in a Merging World," in Jan-Åke Alvarsson and Rita Laura Segato, ed., Religions in Transition, 21.

297 Christian Smith "Correcting a Curious Neglect, or Bringing Religion Back In," in Smith, ed., Disruptive Religion, 21.
} 
When moderate bishops experienced the brutal repression of the Church by military and government powers, many of them shifted their support back to the liberation theology movement .... The bishops ... urged secular leaders to make more radical changes . . 298

Supporting this statement, there is another perspective, relating to the clerics' military attacks. That refers to the regime's offensives against two of the most famous leaders of the Catholic Church in Latin America, Dom Helder Camara from Brazil and Chilean Cardinal Silva, "[b]y attacking the political center of the Church, the military forced the moderates back into the ranks of the progressives." 299 In the event that political opposition forced conservative religious members to join the progressive wing, it could have represented an opportunity of religious transformation. To put in another way, conservative prelates who had taken a neutral stance facing regimes' human right violations, but later assumed denouncing attitudes of the military's abuses, must have experienced religious shifts. This is the case for example, of Salvadoran Archbishop Oscar Romero, who was very traditional and conservative, until Father Rutilio Grande was killed in 1977. Then, Romero became a tiger against the killers that would kill even a priest. Only then did he take up the cause of the peasants and fought for social justice. As I mentioned in chapter 2, Romero was assassinated in 1989 because he denounced government's human rights violations. Romero was beatified in May 2015 by Pope Francis.

\footnotetext{
298 Smith, The Emergence of Liberation Theology, 198.

299 Lernoux, Cry of the People, 46.
} 
I consider this religious change, as a transition from being passive Christians, allowing or even participating in repression against other Christians, to Christians defending Christians. And I am not referring here to changes in political stands, rather, to transformations within the religious spheres as a result of political repression.

Another key point that is important to understand, is that the Latin American progressive Church represented a challenge for the conservative wing and the Vatican hierarchy. As Drogus points out, regardless of the fact that, "Both liberation theology and the CEBs have connections with earlier Catholic social thought (e.g., Leo XIII's 1891 encyclical Rerum Novarum) and lay organizations (Catholic Action in the 1930s)," ${ }^{300}$ different elements of those movements were seized upon by the progressives and conservatives in Latin America, which created tensions with the Vatican hierarchy. The author explains:

the enormous social, political, and religious tumult in Brazil in the 1950 s and 1960s, along with the changes wrought by the Second Vatican Council, combined to ensure that liberationist church evolved in quiet a new direction. Where the preconciliar church had stressed religious authority, personal charity, and elite political action, the liberationist church came to espouse decentralized authority, social justice, and the poor as political actors. ${ }^{301}$

To put it differently, Mainwaring remarks that Popes John XXIII and Paul VI promoted national church autonomy which was a fundamental factor for the Brazilian Church, taking into account its evolution during the 1960s and 1970s.

\footnotetext{
300 Drogus, Women, Religion and Social Change in Brazil's Popular Church, 29.

301 Ibid., 29.
} 
Notwithstanding, Pope John Paul II perceived this autonomy as a threat being aware of the way the Church grew and developed in Brazil and other Latin American nations. ${ }^{302}$ The autonomy of the national Church was a menace because it threatened the monarchical Church structure, as Boff mentioned. ${ }^{303}$ He referred to the authoritarian and absolutist Church where the power is concentrated in few hands, the institution that holds the unique truth. Boff considers this an arrogant attitude that has distanced the Church from modern ideas, democracy and participation. Moreover, Boff remarked his concern about the monosexuality of the Church, ${ }^{304}$ because this condition has not only restricted women's participation, but also it has left aside, and without proper recognition, women's remarkable contribution to the Church through their pastoral work in the CEBs. ${ }^{305}$ Actually, Löwy emphasizes for instance, that more than $60 \%$ (by the 1980s) of the Sao Paulo's (Brazil) CEBs organizations were headed by women. ${ }^{306}$

On the other hand, Vatican's efforts to restore conservativism and centralize authority as in the past, were consolidated during John Paul II's

\footnotetext{
302 Mainwaring, The Catholic church and Politics in Brazil, 1916-1985, 19.

303 Tito González, "Aristegui Marcial Maciel, La Crisis Ideológica De La Iglesia Católica, Entrevista a Leonardo Boff," posted May 31, 2012, accessed January 15, 2016, https://www.youtube.com/watch?v=teTgCApKhxo. (own translation)

304 Ibid.

305 José Luis Velicio, "Leonardo Boff: Teología de la Liberación," posted February 7, 2013, accessed January 15, 2016, https://www.youtube.com/watch?v=ke4CJma8G6U . (own translation)

${ }^{306}$ Löwy, The War of God, 49.
} 
papacy (1979-2005). It is said that even in the Vatican itself existed the premise that,

the only solution for the church is to withdraw to a kind of sectarian ghetto,.[sic] maintaining a surviving remnant of "true believers." Some maintain the church has to become smaller in order to remain faithful. This draws upon a tradition within Catholicism that is based on a sense of the church as a source of absolute truth that acts as a kind of perimeter for believers. There is freedom within its boundaries, but outside of it is the dangerous relativity of the 'world' in our case postmodern secularism, or various forms of totalitarianism. ${ }^{307}$

With this premise in mind, it is not coincidental, as I mentioned in Chapter 3, how traditional Catholic organizations such as Opus Dei and Tradition, Family and Property (TFP) played a key role against progressive religious members of the Church. During the pontificate of John Paul II, the Pope not only empowered the right-wing organization Opus Dei, and gave it the personal prelature, but also supported through his reactionary team of bishops, Tradition, Family and Property (TFP) and the Fatima cult. The latter is a movement characterized as a radical Catholic-anti-communist movement with apocalyptic concerns. The Fatimists group, according to CIA records,

calls for political activism with an arch-conservative bent. The most significant political force directly linked to Fatimists is The Society for the Defense of Tradition, Family, and Property (TFP). ${ }^{308}$

\footnotetext{
307 Fr. Paul Collins, "A Reforming Church with an Unreformed Leadership", National Catholic Reporter, August 13, 1999, accessed January 31, 2016, http://natcath.org/NCR Online/documents/Collins.htm.

308 Walter Sampson, "Fatima," Covert Action, No., 27, Spring 1987. Accessed February 2, 2016. CIA-RDP90-00845R000100170002-7. CIA Records Search Tool (CREST), National Archives and Records Administration, College Park, MD, 47.
} 
Moreover, the cult constituted another strong support for the Vatican's stand against Liberation Theology, since

over the years [by 1987] it has changed and conformed to the interests of different rightists. As the proponents of liberation theology challenge the economic structures that perpetuate poverty, Fatima will no doubt continue to play an important part in the Catholic Right's attempts to stifle progressive change in the church. ${ }^{309}$

Besides Fatimists' radical commitment, and in the light of religious changes, I have to recall Opus Dei's traditional and sectarian customs. Opus Dei holds a strict hierarchy where members are linked to the elites, and must have physical good looks, high social status, professional education, or be comparable in wealth. It has been said that members were encouraged to practice rigorous methods following its religious radicalism such as "mortification of the flesh, ranging from cold showers to self-flagellation." ${ }^{310}$ Similarly, TFP functioned as a Catholic medieval force in the twentieth century, holding a medieval lion as its insignia. Their members belonged to the wealthy classes, and tended to be nationalists as well as xenophobics. During the dictatorships in Chile and Brazil, for example, trained TFP members worked together with the CIA in the persecution of the progressive Catholic Church. ${ }^{311}$

\footnotetext{
309 Ibid.,49.

${ }^{310}$ Fred Landis, "Opus Dei: Secret Order Vies for Power," Covert Action, Nbr. 18, Winter 1983. Accessed June 12, 2015, CIA-RDP90-00845R000100180004-4. CIA Records Search Tool (CREST), National Archives and Records Administration, College Park, MD, 11.

${ }^{311}$ Lernoux, Cry of the People, 294-295.
} 
As shown above, the Vatican's support for these radical and ultraconservative rightwing Catholic groups revealed the nature of the Church led by John Paull II, and its clear objective. The goal was to change the progressive Church, replace it by restoring traditional hierarchical structures and centralizing power and control. These changes directly impacted the Church of the post - II Vatican Council and Medellin: the Church that grew up committed to the poor. As I cited in Chapter 3, Boff stated very clearly in an interview that the Church was not afraid of the theologians but of the Church of the base [CEBs]. The church of base is a new way of being church; it is a community where Archbishops descend, go down to the poor and the poor ascend to the Archbishops. ${ }^{312}$ It means that the Church of the base promoted a close encounter of ordinary members, not only with religious leaders, but also among themselves and with their faith through the Gospel. And, as it was mentioned in the Introduction, the liberationist Church, through the BECs, "came to espouse decentralized authority [and] social justice." ${ }^{313}$ Religious leaders and members of the communities worked together, shared the same reality, and looked for better life conditions through the Christian faith. Constant pastoral education and the study of the Gospel were vehicles to understand and overcome unjust situations. Far from hierarchical structures, BEC's concerns were the extreme conditions of poverty, the lack of basic public services and the different forms of violence in which they were immersed.

\footnotetext{
312 Birgit Kraatz and Manfred Mueller. "No Soy un Hereje" (Lecturas Dominicales, FIU Green Library, Bidegain and Uran Collection, Box 4A, Folder B), 6. (own translation)

313 Drogus, Women, Religion and Social Change in Brazil's Popular Church, 29.
} 
Understanding these contrary positions, on one hand the restoration promoted by John Paul II, versus the Church of the base on the other hand, it is not difficult to identify contradictions within the Catholic communities. These controversies within the Roman Curia impacted the religiosity of Catholic believers, particularly in Latin America.

In this regard, according to the Pew Research Center, since the 1970s, changes began among the religious landscape in the region. In the report Religion in Latin America, Pew's study reveals religious transitions and mobilization within the Christian communities. It says that from 1900 to 1960 s, $90 \%$ of the adult population identified themselves as Catholics. By 2014,

the Pew Research survey shows, $69 \%$ of adults across the region identify as Catholic. In nearly every country surveyed, the Catholic Church has experienced net losses from religious switching, as many Latin Americans have joined evangelical Protestant churches or rejected organized religion altogether. ${ }^{314}$

The study also shows, additional information:

Across Latin America, more than half of those who have switched from the Catholic Church to Protestantism say their new church reached out to them (median of 58\%). And the survey finds that Protestants in the region are much more likely than Catholics to report sharing their faith with people outside their own religious group.

The study of the Pew Research Center provides us with a tendency within Christianity that responds to a variety of reasons. For instance, according to the

\footnotetext{
${ }^{314}$ Pew Research Center, "Religion in Latin America: Widespread Change in a Historically Catholic Region," November 13, 2014, accessed January 31, 2016, http://www.pewforum.org/2014/11/13/religion-in-latin-america/.
} 
study, participants converted to Protestantism for the following reasons, among others:

Seeking personal connection with God (median 81\%)

Enjoy style of worship at new church (median 69\%)

Wanted greater emphasis on morality (median 60\%)

Found church that helps members more (median 59)

Outreach by new church (median 58 ) ${ }^{315}$

I understand from this information, that there is a tendency of some Christians to not fulfill their religious motivations in the Catholic Church; instead, they choose to convert to Protestantism. I believe one of the reasons of these conversions is because of the restoration of the Catholic traditional hierarchical structure and power, which counteracted the Church of the base (BECs), and diminished motivation of the followers. In fact, according to Thomas Reese, from the National Catholic Reporter, the reason for the Catholic exodus "it has little to do with theology and more to do with a desire for emotionally charged worship services and a sense of community, which are absent from most Catholic parishes." ${ }^{316}$ Following Reese's idea for instance, Charismatic movements have become popular since they develop emotionally charged worship services, which is opposite to Catholic masses. For his part, Dussel adds that "Ratzinger restoration, pushed people into the arms of sects of Pentecostalism groups."317|

\footnotetext{
315 Pew, "Religion in Latin America."

316 Thomas Reese, "The Catholic Story, Conservative vs. Progressive", National Catholic Reporter, January 7,2016, accessed January 13, 2016, http://ncronline.org/blogs/faith-andjustice/catholic-story-conservative-vs-progressive.

${ }^{317}$ Enrique Dussel, "From the Second Vatican Council to Present Day," in Dussel, ed., The Church in Latin America 1492-1992, 180.
} 
think Dussel's words expresses another reason regarding conversions to Pentecostalism which is the fact that anyone in the community can become a pastor in a short time, contrary to Catholic priesthood that takes years of study. Pentecostals have also a horizontal and non-hierarchical structure, which provides followers not only a sense of equality, but also promotes companionship and support within the community.

Having in mind the conservative Vatican's characteristics that I have mentioned, and in order to explore different forms of religious transformation as a result of religious repression, let me recall Vatican opposition against Liberation Theology. The ban against former Franciscan Leonardo Boff as well as other cases of the Roman Curia's sanctions will be reviewed in the next section.

\section{The Inquisitorial Church}

Changes in the Vatican's discourse from the visionary and progressive Popes John XXIII and Paul VI, to the conservative John Paul II placed the Church in a controversy. As Kepel well points out:

Liberation Theology was not the only manifestation of the "progressivist mentality" to shake the Church between the end of the council [1965] and the death of Paul VI in 1978. But it represented fairly coherent intellectual construct and appeared to have won over many of the faithful, so that the hierarchy regarded it as the outstanding embodiment of the "Marxist danger" of making the Church into a tool, of tainting its message with left-wing sentiment. This is why the burgeoning re-Christianization movements were to define 
themselves politically and socially by their opposition to that theology. ${ }^{318}$

In an interview, Leonardo Boff remembers that when he was forbidden by the Congregation of the Doctrine of the Faith to travel and speak, he felt that humility was not the same as humiliation, which he considered a kind of oppression. So, he felt he had to follow his truth, the Gospel's truth. The Theology of Liberation is opposed to repression, so if there is repression he had to seek his liberation. Thus, in 1992, he left the priesthood, because as he said, I prefer to change the trench, but not the battle; which is, his battle for the poor. ${ }^{319}$ In fact, since then, Boff by himself, has taken Liberation Theology's message through conferences into different countries, interviews and writings. He has kept working on Liberation Theology and adapting it to the contemporary times. Certainly, the Vatican repression against Boff, took him to leave priesthood, which is a deep religious transformation. In fact, because his controversial case was publicly known, the Catholic hierarchy was highly criticized by other Christians. The National Catholic Reporter recalls, referring to Cardinal Joseph Ratzinger, that "many Catholics with long memories have images in their minds of "God's Rottweiler." 320

\footnotetext{
318 Gilles Kepel, The Revenge of God (University Park, PA: The Pennsylvania State University Press, 1994), 53.

${ }^{319}$ González, "Aristegui Marcial Maciel, La Crisis Ideológica De La Iglesia Católica, Entrevista a Leonardo Boff."

320 Zoe Ryan, "'God's Rottweiler' Silenced Many as Head of Doctrinal Congregation", National Catholic Reporter, February 7, 2013, accessed January 31, 2016, http://ncronline.org/news/vatican/gods-rottweiler-silenced-many-head-doctrinal-congregation.
} 
Besides Boff's case, and as I mentioned in Chapter 3, Ratzinger's discipline imposed on Sister Ivone Gebara and Bishop Dom Casaldaliga of Brazil for example, disrupted their pastoral work, affecting also the believers in their religious jurisdictions. In this regard, John Paul II replaced progressive with conservative religious leaders in "nine of Brazil's thirty-six archdioceses." ${ }^{321}$ Brazilian Catholics were also scandalized by the support of some religious leaders gave to the regime's torture, murder, kidnapping and persecution, similar to the Argentinian case, as it was mentioned in chapter three. This transformed those clerics into a kind of participant in torture, which disillusioned many Catholics. These Catholics may still be believers, but not members of the Church. This disillusion also left many open to other religions, not only Pentecostalism, but other non-Christian religions.

Another example was the expulsion from his religious order of Nicaraguan priest Ernesto Cardenal because of his involvement in politics. Regarding this case, Leonardo Boff insisted in an interview that the conflict between John Paul II and Cardenal was a confrontation between authority and poetry -- mystic poetry that came from the poorest and most miserable places. Boff added that Ernesto Cardenal's participation in a government's ministry was to serve people and to ethically pursue their well-being. He saw that Cardenal was not a bureaucratic governmental minister, but rather a servant of the people. ${ }^{322}$ Berryman confirms

\footnotetext{
${ }^{321}$ Smith, The Emergence of Liberation Theology, 223.

322 Canal de HDTVLAT, "Teología de la Liberación", posted May 25,2008, accessed January 15, 2016, https://www.youtube.com/watch?v=4wMGt2-80E8.
} 
that the Vatican pressured, not only Ernesto Cardenal and his brother, the Jesuit Fernando Cardenal, but also Foreign Minister Miguel D'Escoto, a Maryknoll priest, to leave the priesthood. ${ }^{323}$

On the other hand, it is said that "the shortage of clergy had worked to perpetuate the momentum of the liberation theology movement." ${ }^{324}$ Nevertheless, hierarchical controversies and power pushed priests to abandon the priesthood. In this vein, Colombian conservative Bishop and arch-enemy of Liberation Theology Alfonso Lopez Trujillo, maintained that priests were leaving the ministry because they had been eroding and disturbing, ecclesial homogeneity. ${ }^{325}$ This statement clearly shows that priests leaving the Church were against of the ecclesial homogeneity imposed by hierarchical structures in order to maintain control and power. These controversies within the Church could have prepared the soil for the avalanche of Catholic Charismatic movements during the 1980s. Comblin compares the rapid growth of these movements to Protestant Pentecostalism. The author affirms that Charismatic Renewal,

has an efficient infrastructure, and claims the unconditional support of its faithful. It is constant in its professions of loyalty to the hierarchy, but at the same time is difficult to integrate into diocesan pastoral plans unless the movement itself is the basis of pastoral work. ${ }^{326}$

\footnotetext{
${ }^{323}$ Berryman, Liberation Theology, 108.

${ }^{324}$ Smith, The Emergence of Liberation Theology, 203.

${ }^{325}$ Lopez Trujillo, Liberation or Revolution?,63.

${ }^{326}$ José Comblin, "The Church and Defense of Human Rights," in Dussel, ed., The Church in Latin America 1492-1992, 452.
} 
It seems that Vatican's concerns on restoring the conservative structure of the Church, its power and control, have promoted Catholics' quest for new or different religious experiences. As I have mentioned, some Catholics did not find support within the new Catholic Church's strategy. In fact, Maceoin confirms, referring to Comblin's book, Called for Freedom, The Changing Context of Liberation Theology (1998), that the Church was trying to restore late medieval Christendom created in the

Council of Trent and 16th-century scholasticism. What this means is that the church has painted itself into a corner where it can be of no help to a humanity that desperately needs it. It has no message of hope for the vast and growing human masses that are being rendered superfluous worldwide by neoliberalism. Comblin sees no quick reverse of this new form of apartheid in which the wealthy are physically removing themselves in gated communities from contact with the rest of us. ${ }^{327}$

\section{The Church as Dangerous Place}

In some areas of Central America during the 1970s-1990s, to be a Catholic was dangerous because it was to be seen as a guerrilla sympathizer. For this reason, the brutal repression against Catholics committed to the poor occurred, bringing some changes to Christianity. For example, in Guatemala and El Salvador evangelical churches became a refuge from the violence, so they experienced an increasing rate of conversions. Evangelical churches were considered "apolitical and/or supportive of the military and their counter-

\footnotetext{
${ }^{327}$ Gary Maceoin, "Gospel of Liberation More Urgent than Ever," National Catholic Reporter, September 4, 1998, accessed February 1, 2016, http://natcath.org/NCR Online/archives2/1998c/090498/090498w.htm.
} 
insurgency policies (which, of course, is not considered by the authorities as being 'political')." ${ }^{328}$ In this case, opposition to the progressive Catholic Church linked to Liberation Theology promoted the conversion of Catholics to evangelical Protestantism as a survival option. The risk of being persecuted because of religious affiliation was a fact, as Salvadoran Jesuit Rutilio Grande said a month before he was murdered, "Nowadays it is dangerous ... and practically illegal to be an authentic Christian in Latin America." ${ }^{329}$ Religious changes in this case occurs, when

people change their old religious affiliations for alternative ones that have become available through missionary work or other situation of cultural contact. In this process, the incoming creeds will suffer transformations in the new cultural soil through a variety of processes of absorption that normally follow the encounter of two organized set of beliefs. ${ }^{330}$

\section{Military Repression to Radicalize the Popular Church}

In contrast to this religious conversion seeking to escape from violence, Erickson says that the repression of the military regimes of El Salvador and Nicaragua "strengthened and radicalized members of the popular church." 331 This is possible when the church has empowered the poor, and given them the

\footnotetext{
${ }^{328}$ Löwy, The War of Gods, 115.

${ }^{329}$ Lernoux, Cry of the People, 13.

${ }^{330}$ Rita Laura Segato, "Religions in Transition: Changing Religious Adhesions in a Merging World," in Jan-Åke Alvarsson and Rita Laura Segato, ed., Religions in Transition, 11.

331 Sharon Erickson Nepstad, "Popular Religion, Protest, and Revolt," in Smith, ed., Disruptive Religion: The Force of Faith in Social-Movement Activism (New York, London: Routledge, 1996), 117.
} 
hope to change their conditions. The author remarks that the regimes' repression worsened the life conditions of the poor, so members of the popular church believed that by staying and radicalizing their activities in the Christian Communities they would accomplish social justice. Radicalization represented the force for social change as an expression of their religious faith. This radicalization may have eventually led to take revolutionary and political paths, as was the case of some members of the communities of Solentiname in Nicaragua, and Suchitoto in El Salvador in the 1970s. ${ }^{332}$ But in other cases, Catholics radicalized their commitment through the conviction that change is possible through faith. In fact,

studies support the thesis of the theology of liberation that when small groups of poor people achieve a reasonable level of solidarity with the support of an institutional power such as the Church, they can effect radical change from within the community. ${ }^{333}$

Or in Boff's words, Liberation Theology provides Christianity with a liberationist perspective and a symbolic capital, through which Christianity may promote a process of social mobilization and change through faith. ${ }^{334}$

\section{Prison - Repression to strengthen Christianity}

Carlos Alberto Libânio Christo, better known as Frei Betto, is a Brazilian Dominican priest, a promoter of Liberation Theology who suffered political

\footnotetext{
332 Ibid., 118-120.

333 Lernoux, Cry of the People, 406.

334 José Luis Velicio, "Leonardo Boff: Teología de la Liberación," posted February 7, 2013, accessed January 15, 2016, https://www.youtube.com/watch?v=ke4CJma8G6U .
} 
repression. He was in jail for four years in the 1970s, and he sustains that prison gave him the opportunity to go deeper into his Christian life. During prison, he organized a kind of Base Ecclesial Community (BEC) within the penal institution, where he developed religious and educational courses. For instance, he set up theater classes, Biblical reading groups, drawing and high school courses and established a Library. Frei Betto considered that educational programs provided in the CEBs led people to change their conditions. He worked with around eighty prisoners, who, with some exceptions, were able to build up a new life consciousness. He adds that thanks to the Brazilian Generals he became a professional writer. ${ }^{335}$ Under these circumstances, it is important to realize that religious transformation occurred not only for Frei Betto, but also for those prisoners who were exposed to his religious teachings. I would say that Frei Betto developed a missionary work in jail implementing his educational and pastoral work. On the other hand, I also understand that Frei Betto experienced a religious transformation living his priesthood outside the Catholic hierarchical structure, when he said that his Christianity was fortified during his time in jail. And it is important to recall that conservative Brazilian Bishops gave their back to Frei Betto and the other Dominican Priest, Frei Tito, and praised their prison sentences because of their links with "communists."336

\footnotetext{
${ }^{335}$ E.D.H Cuba, "Entrevista a Frei Betto por Esther Pérez, El socialismo es una exigencia de mi fe cristiana, pero también es la única esperanza que tengo de una humanidad verdaderamente humana," posted December 12,2012, accessed January 18, 2016, https://www.youtube.com/watch?v=hA85m4M4IrM.
}

${ }^{336}$ Serbin, Secret Dialogues, 131-132. 
Frei Betto's colleague, Frei Tito, had a different fate. Beginning in 1963, he participated in Catholic Action and was a promoter of Liberation Theology. Frei Tito suffered tremendously in prison because of the brutal repression and torture inflicted on him. After jail, he was sent to Europe to a Dominican monastery, but his mind was hounded by his tortures, and he committed suicide in $1974 .{ }^{337}$ Frei Tito's remains were returned to Brazil, where in an emotive event Cardinal Paulo Evaristo Arns said, that Frei Tito did not kill himself, he looked for the unity that he had not found on this side of death. ${ }^{338}$ The words of Cardinal Arns -- advocate of Liberation Theology -- refer clearly to the divisions within the Brazilian Catholic Church, which led to Frei Tito's and Betto's kismets. Indeed, it seems clear that divisions within the Church and subsequent religious repression promoted changes in both Frei Tito's and Frei Betto's religiosity, by leaving them alone in their calvary.

337 Ibid.

${ }^{338}$ E.D.H Cuba, "Entrevista a Frei Betto por Esther Pérez, El socialismo es una exigencia de mi fe cristiana, pero también es la única esperanza que tengo de una humanidad verdaderamente humana," posted December 12,2012, accessed January 18, 2016, https://www.youtube.com/watch?v=hA85m4M4IrM . 


\section{Conclusion}

Political, social and religious opposition to Liberation Theology led to Christian transformation in many ways, from assassination, persecution and imprisonment of clerical, religious and lay members of progressive Catholic groups, through Vatican censures of leading figures and replacement of progressive and moderate bishops with reactionary bishops, to the promotion and support of other religious groups to counteract the liberationist Catholic movement. In the Cold War context, this was possible, even necessary under the National Security Doctrine that linked Liberation Theology with communists; it represented a subversive element. But it is interesting that even though the National Security Doctrine justified the repression against Liberation Theology, nobody was able to prove that the liberationist movement was communist.

Besides, on the one hand, thanks to the rapid development of communications, urbanization and global trade, Liberation Theology spread across the region. But, on the other hand, among these Globalization features, advancements in military technology unleashed the repression against the religious movement across the region. Therefore, repression against Liberation Theology became a transnational practice in Latin American.

It is important to realize how a religious movement such as Liberation Theology signified a problem for national security and was identified as subversive because of its commitment with the poor. Its engagement for radical social change and the quest of liberation from extreme poverty made the religious movement a threat for conservative and right wing sectors in Latin 
America, which together with the U.S. anti-communist crusade repressed Liberation Theology with the support of local governments, elites, religious leaders and the Vatican.

National Security Doctrine saw the religious project as a political threat to the state, based as it was on a foundation of historic class-based injustice, so there was only one strategy to counter act that religious project, repression. The menace of Liberation Theology was that it promoted social movements to help people change their reality. Liberation Theology is not only the product of a reflection, but also proposes a praxis to transform the unjust reality. Thus, reflection and praxis work together, one feeds the other. This reflection and praxis promoted by Liberation Theology made it different from the ecclesial movements, because these religious groups were focused just in pastoral work and not in social change. Therefore, Liberation Theology, applying its See, Judge and Act methodology, encouraged social justice. Marginalized and oppressed people learned how to understand their reality and changed it. As soon as they began to participate in projects to generate changes in their communities in light of the Gospel, they shifted their identity from invisible and marginalized people to citizens who worked and claimed for their rights. And this was the most dangerous aspect of Liberation Theology, because in an environment where the region was conducted by authoritarian regimes, participation of the people in social change was against the status quo and could promote democracy, which by that time threatened the stability of the military regimes. 
Nonetheless, it was not enough to counteract Liberation Theology with political repression, prison, torture and even murder. The power of the Liberation Theology movement to motivate and energize bodies and souls explains why it was deemed necessary to join efforts to attack it from other fields, the social and religious spheres. It was a coordinated operation clearly planned not only to annihilate Liberation Theology, but also to divide the Church, to provoke a schism within one of the most powerful religious institutions, the Catholic Church. In this vein, this work has explained how the conservative sector of the Catholic Church and the Vatican during the John Paul II's papacy dismantled and undermined the progressive church of the Second Vatican Council. Moreover, after it had empowered the laity, which had filled the shortage of priests, and organized the Church, it discouraged them. This fact opened the space for believers and religious leaders to look for other religions.

The research also helped us to understand the lack of information on the opposition against Liberation Theology. Although there are many resources, both academic and popular, in English, it is possible that a great number of Latin American readers who remember the 1970s never heard about Liberation Theology, the participation of the Catholic Church in human rights defense, its commitment with the poor or the Base Ecclesial Communities. The reason is that the Latin American press was controlled. For security reasons information was restricted and in many Latin American countries the press was censored. Besides, powerful elite groups such as the Bilderberg Group, which has as a goal to establish a universal religion, controlled the many principal news media outlets 
in the world. ${ }^{339}$ Members of this group are important international politicians, financers, bankers, businessmen -- such as the Rockefellers -- heads of governments and journalists. It was not until 1985 that Liberation Theology was in the news in Latin America. Sociologist of religion Otto Maduro, remembered, that:

When [Leonardo] Boff was condemned, liberation theology became a hot thing everywhere in Latin America. Many Catholics had never heard of liberation theology until then. After, millions were exposed to the claims of liberation theology. Millions. ${ }^{340}$

This research has revealed the great impact of Liberation Theology in the twentieth century. It was considered the big victory that brought a theological change after two thousand years of the Catholic thought. Liberation Theology also inspired similar theologies in fields where oppression was present. Thus, soon emerged Black Theology, Feminist Theology, Ecology and Liberation and Indian Theology of Liberation.

In the final analysis, I can conclude that religious transformation occurred as a consequence of the opposition to Liberation Theology because repression pushed followers to experience their religiosity in different directions. There is causality, a cause-effect relationship between the repression against Liberation Theology and religious changes as the effect of such opposition. Thus, some had to look for refuge in distinct religious groups, others radicalized their Catholicism,

\footnotetext{
339 Daniel Estulin, The True Story of the Bilderberg Group, North American Union Edition (Chicago: Independent Publishers Group (IPG), 2009), 41,43.

${ }^{340}$ Smith, The Emergence of Liberation Theology, 193.
} 
some others left the priesthood and other believers decided to abandon the Catholic Church due to the hierarchical structure, power and control. 


\section{References}

Allen Jr., John L. "These paths lead to Rome: Six cardinals who got to the curia by supporting right-wing governments in Latin America, opposing liberation theology". National Catholic Reporter. June 2, 2000. Accessed January 7, 2016. http://natcath.org/NCR Online/archives2/2000b/060200/060200a.htm.

"The Vatican's Enforcer." National Catholic Reporter. April 16, 1999. Accessed January 15, 2016, http://natcath.org/NCR_Online/archives2/1999b/041699/041699a.htm

Alvarsson,Jan Åke and Rita Laura Segato. Religions in Transition: Mobility, Merging and Globalization in Contemporary Religious Adhesions. Uppsala: Uppsala University Library, 2003.

Azevedo, Marcelo de C. S.J., Basic Ecclesial Communities in Brazil: The Challenge of a New Way of Being Church. Washington D.C: Georgetown University Press, 1987.

Bahmann, Manfred K.A Preference for the Poor: Latin American Liberation Theology from a Protestant Perspective. Lanham, Md: University Press of America, 2005.

Batstone, David B. Liberation Theologies, Postmodernity, and the Americas. London ; New York: Routledge, 1997.

Berryman, Phillip. Liberation Theology: Essential Facts about the Revolutionary Religious Movement in Latin America and Beyond. New York: Pantheon Books, 1987.

Berryman, Phillip. Stubborn Hope: Religion, Politics, and Revolution in Central America. Maryknoll, N.Y: Orbis Books, 1994.

Bidegain, Ana María. Historia del Cristianismo en Colombia, Corrientes y Diversidad. Bogotá: Taurus, 2004.

Bidegaín, Ana María, Juan Diego Demera Vargas, and Instituto Colombiano para el Estudio de,las Religiones. Globalización y Diversidad Religiosa En Colombia. 1. ed. Bogotá: Universidad Nacional de Colombia, Facultad de Ciencias Humanas, 2005.

Bidegaín, Ana María and Helen Kellogg Institute for International Studies. From Catholic Action to Liberation Theology: The Historical Process of the Laity in 
Latin America in the Twentieth Century. Notre Dame, IN, USA: Helen Kellogg Institute for International Studies, University of Notre Dame, 1985.

Bidegain de Uran, Ana María. Nacionalismo, Militarismo y Dominación en América Latina. Bogotá: Facultad de Filosofía y Letras, Departamento de Historia, Edición Universidad de Los Andes, 1983.

Blosser, Christopher. "Towards a Proper Appreciation of Liberation Theology, Some Resources from Pope John Paul II." The American Catholic. December 22, 2009. Accessed February 19, 2016. http://the-americancatholic.com/2009/12/22/towards-a-proper-appreciation-of-liberationtheology-some-resources-from-pope-john-paul-ii/

Boff, Leonardo and John W. Diercksmeier, trans. Church, Charism and Power: Liberation Theology and the Institutional Church. New York: The Crossroad Publishing Company, 1985.

Church: Charism and Power. Liberation Theology and the Institutional Church.Eugene, OR: Wipf \& Stock, 1985

Bonnin, Juan E. Discurso Político y Discurso Religioso En América Latina: Leyendo Los Borradores De Medellín (1968). Buenos Aires: Santiago Arcos editor, 2013.

Bruneau, Thomas C. "Obstacles to Change in the Church: Lessons from Four Brazilian Dioceses." Journal of Interamerican Studies and World Affairs 15, no. 4 (1973): 395-414.

Budde, Michael L. The Two Churches: Catholicism and Capitalism in the WorldSystem. Durham, NC: Duke University Press, 1992.

Câmara, Hélder. Spiral of Violence. London: Sheed and Ward, 1971.

Canal de HDTVLAT. "Teología de la Liberación". Posted May 25,2008. Accessed January 15, 2016. https://www.youtube.com/watch?v=4wMGt2-80E8

Candelaria, Michael R. Popular Religion and Liberation: The Dilemma of Liberation Theology. Albany: State University of New York Press, 1990.

Catholic Church Archdiocese, of S. and Joan Dassin. Torture in Brazil: A Shocking Report on the Pervasive use of Torture by Brazilian Military Governments, 1964-1979. First University of Texas Press ed. ed. Austin, Tex: Institute of Latin American Studies, University of Texas, 1998. 
Chaouch, Malik Tahar. "La Teología De La Liberación En América Latina: Una Relectura Sociológica / Liberation Theology in Latin America: A Sociological Reinterpretation." Revista Mexicana De Sociología69, no. 3 (Jul. - Sep., 2007): 427-456.

Cleary, Edward L., and Timothy J. Steigenga. Resurgent Voices in Latin America Indigenous Peoples, Political Mobilization, and Religious Change. New Brunswick, N.J: Rutgers University Press, 2004.

Collins, Paul. "Paul Collins' Explanation of his Resignation from the Priesthood", National Catholic Reporter. March 9, 2001. Accessed January 17, 2016, http://natcath.org/NCR_Online/documents/CollinsREASONS.htm

Collins, Paul Fr. "A Reforming Church with an Unreformed Leadership." National Catholic Reporter. August 13, 1999. Accessed January 31, 2016, http://natcath.org/NCR_Online/documents/Collins.htm

Comblin, José. Doctrina De Seguridad Nacional. 1a ed. San José, Costa Rica: Editorial Nueva Década, 1988.

Congregación para la Doctrina de la Fe. "Instrucción Sobre Libertatis Conscientia, sobre Libertad Cristiana y Liberación." Vatican, March 22, 1986. Accessed October 13,2015.

http://www.vatican.va/roman_curia/congregations/cfaith/documents/rc_con_c faith_doc_19860322_freedom-liberation_sp.html

Congregation of the Doctrine of the Faith. "Instruction of Certain Aspects of the Theology of Liberation." Vatican, August 6,1984. Accessed October 13, 2015.

http://www.vatican.va/roman_curia/congregations/cfaith/documents/rc_con_c faith_doc_19840806_theology-liberation_en.html

Cook, Guillermo. New Face of the Church in Latin America: Between Tradition and Change. Maryknoll, N.Y: Orbis Books, 1994.

Cousineau, Madeleine. Religion in a Changing World: Comparative Studies in Sociology. Westport, Conn: Praeger, 1998.

Da Silveira, Consul in Recife, to Secretary of State, Washington, Telegram, September 8, 1972. General Records 59, Subject Numeric Files 1970-73, SOC 6-2 BRAZ to SOC 14 BRAZ, Box 3054, National Archives and Records Administration, College Park, MD.

Dorr, Donal. Option for the Poor: A Hundred Years of Vatican Social Teaching. Rev. ed. Maryknoll, N.Y: Orbis Books, 1992. 
Drogus, Carol Ann and Helen Kellogg Institute for International Studies. Women, Religion, and Social Change in Brazil's Popular Church. Notre Dame, ID: University of Notre Dame Press, 1997.

Dussel, Enrique. La Iglesia Latinoamericana de Sucre a Santo Domingo (19721992). Asunción: CEHILA-CONFERPAR, 1993.

Enrique Dussel, ed. and CEHILA, Commission for the Study of Church History in Latin America. The Church in Latin America, 1492-1992. Tunbridge Wells, Kent England]: Maryknoll, N.Y: Burns \& Oates; Orbis Books, 1992.

E.D.H Cuba. "Entrevista a Frei Betto por Esther Pérez. El socialismo es una exigencia de mi fe cristiana, pero también es la única esperanza que tengo de una humanidad verdaderamente humana." Posted December 12,2012. Accessed January 18, 2016.https://www.youtube.com/watch?v=hA85m4M4IrM

Estulin, Daniel. The True Story of the Bilderberg Group. 2nd ed. (North American Union) ed. Walterville, OR: TrineDay, 2009.

Fernández, David. La "Iglesia" Que Resistió a Pinochet: Historia, Desde La Fuente Oral, Del Chile Que no Puede Olvidarse. Madrid: IEPALA, 1996.

Finchelstein, Federico. The Ideological Origins of the Dirty War: Fascism, Populism, and Dictatorship in Twentieth Century Argentina. Oxford, New York: Oxford University Press, 2014.

González, Ondina E. and Justo L. González. Christianity in Latin America: A History. Cambridge; New York: Cambridge University Press, 2008.

González, Tito. "Aristegui Marcial Maciel, La Crisis Ideológica De La Iglesia Católica, Entrevista a Leonardo Boff." Posted May 31, 2012. Accessed January 15, 2016, https://www.youtube.com/watch?v=teTgCApKhxo

Green, James Naylor. We Cannot Remain Silent: Opposition to the Brazilian Military Dictatorship in the United States. Durham, NC: Duke University Press, 2010.

Guio, José María. "The Latin American Church in the Wojtyla's era New Evangelization or Neo-Integralism." Kellogg Institute 159 (1991):3. Accessed January 20, 2016.

http://kellogg.nd.edu/publications/workingpapers/WPS/159.pdf 
Guralnik, David B. and Victoria Neufeldt, eds., Webster's New World Dictionary of American English, Third College Edition. Cleveland, New York: Simon \&Schuster, Inc, 1988.

Gutiérrez, Gustavo. The Truth Shall Make You Free: Confrontations. Maryknoll, N.Y: Orbis Books, 1990.

Gutiérrez, Gustavo and Richard Shaull, Liberation and Change. Atlanta: John Knox Press, 1977.

Hynds, Patricia. "The Ideological Struggle within the Catholic Church in Nicaragua", Covert Action, No. 18, Winter 1983, P. 17. Accessed June 9, 2014. CIA-RDP90-00845R000100180004-4. CIA Records Search Tool (CREST), National Archives and Records Administration, College Park, MD.

Jones, Arthur. "Documents reveal nuncio's cautious human rights stance", National Catholic Reporter. August 30, 2002. Accessed January 8, 2016. http://natcath.org/NCR Online/archives2/2002c/083002/083002m.htm

Jones, Arthur and NCR Staff. "A Look at Declassified State Department Documents." National Catholic Reporter. September 23, 1994. Accessed December 15,2015. http://natcath.org/NCR Online/archives2/1994c/092394/092394v.htm

Karuze, Charles A. "For U.S. Priest in Chile, 'Liberation Theology' Means Bringing Dignity to Poor". The Washington Post, February 14, 1979. Accessed January 7, 2016. https://www.washingtonpost.com/archive/politics/1979/02/14/for-us-priest-inchile-liberation-theology-means-bringing-dignity-to-poor/53ed0b79-6c794024-a240-719f37f47009/

Kepel, Gilles. The Revenge of God: The Resurgence of Islam, Christianity, and Judaism in the Modern World. University Park, Pa: Pennsylvania State University Press, 1994.

Kickham, Larry. "The Theology of Nuclear War. The Full Gospel Business Men's Fellowship International (FGBMFI)". Covert Action, No. 27, Spring 1987. Accessed June 9, 2014. CIA-RDP90-00845R000100170002-7, CIA Records Search Tool (CREST), National Archives and Records Administration, College Park, MD.

Kissinger, Henry. "Report of the National Bipartisan Commission on Central America, January 10, 1984." Accessed June 10, 2015. CIARDP86M00886R001200340040-1. CIA Records Search Tool (CREST), National Archives and Records Administration, College Park, MD. 
Klaiber, Jeffrey L. The Church, Dictatorships, and Democracy in Latin America. Maryknoll, N.Y: Orbis Books, 1998.

Korry, Edward. "The Sell-Out of Chile and The American Tax Payer", Penthouse Magazine. March 1978. Accessed June 9, 2014. CIA-

RDP09t00207r001000030065-1. CIA Records Search Tool (CREST), National Archives and Records Administration, College Park, MD.

Kraatz, Birgit and Manfred Mueller. "No Soy un Hereje".Lecturas Dominicales. FIU Green Library, Bidegain and Uran Collection, Box 4A, Folder B.

Landis, Fred. "Opus Dei: Secret Order Vies for Power." Covert Action Nbr. 18, Winter 1983. Accessed June 12, 2015. CIA-RDP90-00845R0001001800044. CIA Records Search Tool (CREST), National Archives and Records Administration, College Park, MD.

Lehmann, David. Struggle for the Spirit: Religious Transformation and Popular Culture in Brazil and Latin America. Cambridge, Mass: Polity Press, 1996.

Leo XIII, "Rerum Novarum". The Vatican. May 15, 1891. Accessed January 31, 2016, http://w2.vatican.va/content/leo-xiii/en/encyclicals/documents/hf_Ixiii_enc_15051891_rerum-novarum.html

Lernoux, Penny. Cry of the People: The Struggle for Human Rights in Latin America The Catholic Church in Conflict with U.S. Policy. New York, N.Y: Penguin Books, 1982.

Levine, Daniel $\mathrm{H}$. "Assessing the Impacts of Liberation Theology in Latin America." The Review of Politics 50, no. 2 (Spring, 1988): 241-263.

López Trujillo, Alfonso. Liberation Or Revolution?: An Examination of the Priest's Role in the Socioeconomic Class Struggle in Latin America. Huntington, ID: Our Sunday Visitor, 1977.

Löwy, Michael. The War of Gods: Religion and Politics in Latin America. London, New York: Verso, 1996.

Lynch, John. New Worlds: A Religious History of Latin America. New Haven: Yale University Press, 2012.

Lyons, Barry J. Remembering the Hacienda: Religion, Authority, and Social Change in Highland Ecuador. 1st ed. ed. Austin: University of Texas Press, 2006. 
Mainwaring, Scott. The Catholic Church and Politics in Brazil, 1916-1985. Stanford, Calif: Stanford University Press, 1986.

McDonagh, Francis. "Brazilian Archbishop's Vision still Challenges Church", National Catholic Reporter. October 1, 2004. Accessed January, 16, 2015, http://natcath.org/NCR_Online/archives2/2004d/100104/100104l.php

Gary Maceoin, "Gospel of Liberation more urgent than ever."National Catholic Reporter. September 4, 1998. Accessed February 1, 2016, http://natcath.org/NCR_Online/archives2/1998c/090498/090498w.htm

McSherry, J. Patrice. Predatory States: Operation Condor and Covert War in Latin America. Lanham, MD: Rowman \& Littlefield Publishers, Inc, 2005.

Mecham, J. L. Church and State in Latin America; a History of PoliticoEcclesiastical Relations. Rev. ed. ed. Chapel Hill: University of North Carolina Press, 1966.

Molineaux, David."Chile honors memory of cardinal who opposed Pinochet". National Catholic Reporter, April 23, 1999. Accessed January 6, 2015. http://natcath.org/NCR_Online/archives2/1999b/042399/042399i.htm

Morello, Gustavo. The Catholic Church and Argentina's Dirty War. New York, NY: Oxford University Press, 2015.

Nikolas Kozloff. "The Pope's Holy War Against Liberation Theology." Accessed March 11, 2015. https://nacla.org/news/popes-holy-war-against-liberationtheology.

Patte, Daniel. The Cambridge Dictionary of Christianity. Cambridge, New York: Cambridge University Press, 2010.

Paulus PP. VI. "Evangelii Nuntiandi." Vatican. Accessed March 13, 2015 . http://w2.vatican.va/content/paul-vi/en/apost exhortations/documents/hf pvi exh 19751208 evangelii-nuntiandi.html.

Pernas, Walter. "En Dictadura y en Democracia. La Persecución a "Perico" Pérez Aguirre", Servicio Paz y Justicia Uruguay, SERPAJ, September 30 , 2005, accessed January 5, 2016, http://www.serpaj.org.uy/serpajph/comunicacion/spjprensa/210_05.pdf

Pope John Paul II. "Apostolos Suos." Vatican, Apostolic Letter. May 21, 1998. Accessed December 23, 2015, http://w2.vatican.va/content/john-paulii/en/motu_proprio/documents/hf_jp-ii_motu-proprio_22071998_apostolossuos.html 
"Laborem Exercens." Vatican. Accessed March 13.

2015. http://w2.vatican.va/content/john-paul-

ii/en/encyclicals/documents/hf ip-ii enc 14091981 laborem-exercens.html.

. "Third General Conference of the Latin American Episcopate (Puebla, MX)." Vatican. Accessed March 11, 2015, . http://w2.vatican.va/content/johnpaul-ii/en/speeches/1979/january/documents/hf ip-

ii spe 19790128 messico-puebla-episc-latam.html.

Pope Paul VI. "Christus Dominus". Vatican, Decree, October 28, 1965. Accessed December 23, 2015,

http://www.vatican.va/archive/hist_councils/ii_vatican_council/documents/vat -ii_decree_19651028_christus-dominus_en.html

Pope Paul VI. "Populorum Progressio." Vatican. Accessed March 13, 2015

. http://w2.vatican.va/content/paul-vi/en/encyclicals/documents/hf p-

vi enc 26031967 populorum.html.

Posner, Gerald L. God's Bankers: A History of Money and Power at the Vatican. First Simon \& Schuster hardcover edition. ed. New York: Simon \& Schuster, 2015.

Reese, Thomas. "The Catholic Story, Conservative vs. Progressive." National Catholic Reporter. January 7,2016. Accessed January 13, 2016, http://ncronline.org/blogs/faith-and-justice/catholic-story-conservative-vsprogressive

Regan, David. Why are they Poor?: Helder Camara in Pastoral Perspective. Münster: Lit, 2002.

"Religion in Latin America, Widespread Change in a Historically Catholic Region." Pew Research Center. November 13, 2014. Accessed January 31, 2016. http://www.pewforum.org/2014/11/13/religion-in-latin-america/

Rubenstein, Richard L. and Washington Institute for Values in Public Policy. The Political Significance of Latin-American Liberation Theology / by Richard L. Rubenstein. Washington, DC: Washington Institute for Values in Public Policy, 1986.

Rueda Navarro, Edgar Camilo. "Biografía Política de Camilo Torres." El Ortiba, (n.d). Accessed February 7, 2016. http://www.elortiba.org/camilo.html.

Ryan, Ryan. "'God's Rottweiler' silenced Many as Head of Doctrinal Congregation." National Catholic Reporter. February 7, 2013. Accessed 
January 31, 2016. http://ncronline.org/news/vatican/gods-rottweiler-silencedmany-head-doctrinal-congregation.

Sampson, Walter. "Fatima."Covert Action, Nbr., 27, Spring 1987. Accessed February 2, 2016. CIA-RDP90-00845R000100170002-7. CIA Records Search Tool (CREST), National Archives and Records Administration, College Park, MD.

Serbin, Ken. Secret Dialogues: Church-State Relations, Torture, and Social Justice in Authoritarian Brazil. Pittsburgh, Pa: University of Pittsburgh Press, 2000.

Servicio Paz, y. Justicia. Uruguay Nunca Más: Human Rights Violations, 19721985. Philadelphia: Temple University Press, 1992.

Sigmund, Paul E. Liberation Theology at the Crossroads: Democracy Or Revolution?. New York: Oxford University Press, 1990.

Sigmund, Paul E., ed. Religious Freedom and Evangelization in Latin America: The Challenge of Religious Pluralism. Maryknoll, N.Y: Orbis Books, 1999.

Smith, Brian $\mathrm{H}$. and Helen Kellogg Institute for International Studies. Religious Politics in Latin America, Pentecostal Vs. Catholic. Notre Dame, ID: University of Notre Dame Press, 1998.

Smith, Christian, ed. Disruptive Religion: The Force of Faith in Social-Movement Activism. New York: Routledge, 1996.

Smith, Christian. The Emergence of Liberation Theology: Radical Religion and Social Movement Theory. Chicago: University of Chicago Press, 1991.

Tombs, David. Latin American Liberation Theology. Boston: Brill Academic Publishers, 2002.

Torres, Carlos Alberto. The Church, Society, and Hegemony: A Critical Sociology of Religion in Latin America. Westport, Conn: Praeger, 1992.

United States Conference of Catholic Bishops. "The New American Bible." Accessed June 15, 2015. http://wwwmigrate.usccb.org/bible/books-of-thebible/index.cfm

U.S. Information Agency ,"Liberation Theology and Anti-Americanism: The Challenge to U.S. interests in Latin America." June 4, 1987. General Records 0306, Research Memoranda 1963-1999, Entry 64, M-9-17-1986 
thru M-3-24-1988, Box 43. National Archives and Records Administration, College Park, MD.

U.S. Department of State to ARA/BR: WDMCLAIN.JR:ME, Outgoing Telegram, September 12, 1972. General Records 59, Subject Numeric Files 197073, SOC 6-2 BRAZ to SOC 14 BRAZ, Box 3054, National Archives and Records Administration, College Park, MD.

U.S. Directorate of Intelligence, "Chile's Cardinal Fresno, a Political Primate, ALA-M-85-10117, November 6, 1985." Accessed June 9, 2015. CIARDP85T01058R000100570001-3. CIA Records Search Tool (CREST), National Archives and Records Administration, College Park, MD.

U.S. Directorate of Intelligence, "Latin America Review, ALA LAR 85-022. October 11, 1985." Accessed June 10, 2015. CIARDP87T00289R000200910001-7. CIA Records Search Tool (CREST), National Archives and Records Administration, College Park, MD.

U.S. Directorate of Intelligence, "Liberation Theology: Religion, Reform, and Revolution, Gl 86-10028, April 1986." Accessed June 8, 2015. CIA-RDP 97R00694R000600050001-9, CIA Records Search Tool (CREST), National Archives and Records Administration, College Park, MD.

Vásquez, Manuel A. The Brazilian Popular Church and the Crisis of Modernity. Cambridge; New York, NY, USA: Cambridge University Press, 1998.

Vatican. "Compendium of the Social Doctrine of the Church." . http://www.vatican.va/roman curia/pontifical councils/justpeace/documents Irc pc justpeace doc 20060526 compendio-dott-soc en.html.

Velicio, Jose Luis. "Leonardo Boff: Teología de la Liberación." Posted February 7, 2013. Accessed January 15, 2016.

https://www.youtube.com/watch?v=ke4CJma8G6U

Yallop, David A. The Power and the Glory: Inside the Dark Heart of John Paul II's Vatican. New York, NY: Carroll \& Graf Publishers, 2007. 